\title{
COMPORTAMENTO DAS FIBRAS DE VIDRO CONVENCIONAIS EM MATRIZ DE CIMENTO PORTLAND MODIFICADA COM LÁTEX E ADIÇÃO DE SÍLICA ATIVA
}

\author{
Antônio de Paulo Peruzzi
}

Dissertação apresentada à Escola de Engenharia de São Carlos da Universidade de São Paulo, como parte dos requisitos para obtenção do título de mestre em arquitetura

ORIENTADOR:

Prof. Dr. Osny Pellegrino Ferreira

São Carlos

2002 


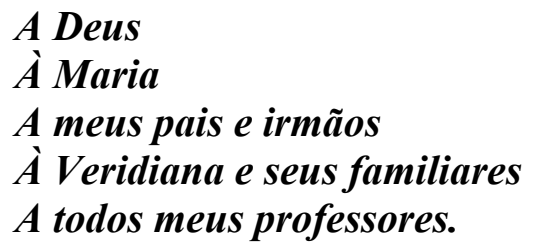




\section{Agradecimentos}

Ao professor Osny Pellegrino Ferreira pela orientação.

A Paulo e Sérgio, técnicos do Laboratório de Construção Civil da EESC.

Aos professores e funcionários do Departamento de Arquitetura e Urbanismo.

À Owens Corning do Brasil, principalmente ao Dr. Edouard Zurstrassen, pelo fornecimento das fibras e orientação técnica.

À Ciminas, à MBT do Brasil, à Rhodia do Brasil e Microssílica Elken pelo fornecimento dos outros materiais necessários para desenvolvimento desta pesquisa. 


\section{SUMÁRIO}

LISTA DE FIGURAS

LISTA DE TABELAS

LISTA DE SIMBOLOS

LISTA DE ABREVIATURAS E SIGLAS

RESUMO

ABSTRACT

\section{Introdução}

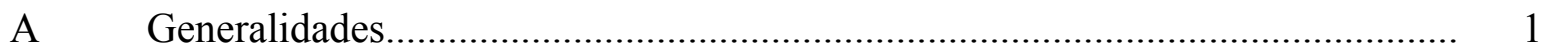

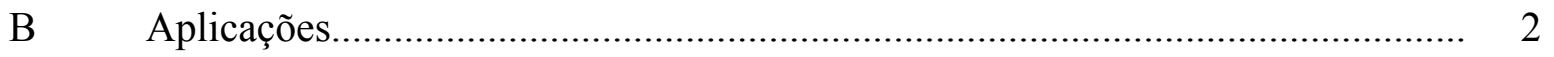

C Características mecânicas desejáveis........................................................... 3

D Limitações da fibra de vidro e possíveis maneiras de contornar suas deficiências........................................................................................ 3

E Formulação da situação-problema................................................................. 4

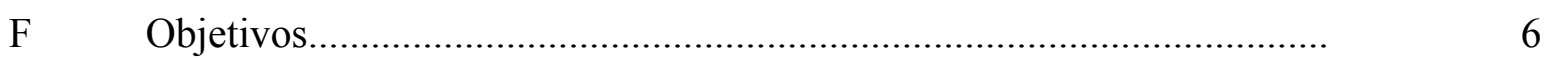

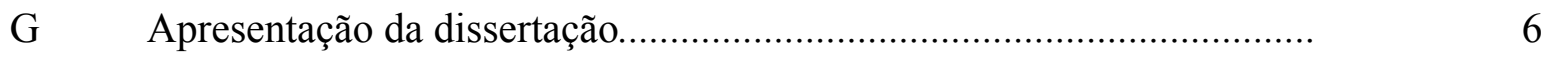

\section{Cimento Portland}

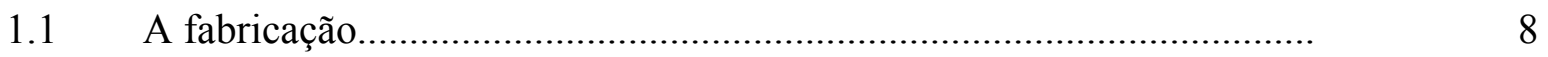

1.2 Importância de cada fase na qualidade final dos cimentos.............................. 9

1.3 Composição química do cimento Portland....................................................... 9

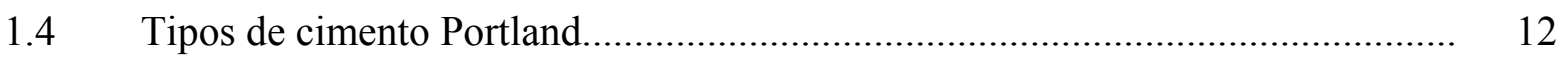

1.5 Principais produtos da hidratação do cimento Portland..................................... 14

1.6 Minerais adicionados aos cimentos no Brasil.................................................. 15

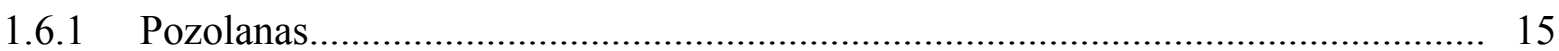

1.6.2 Escória granulada de alto forno................................................................ 15

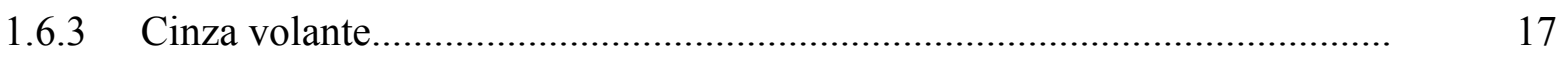




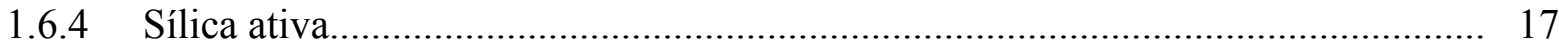

1.7 Estudo da alcalinidade da matriz de cimento Portland.......................................... 18

1.7.1 A água dos poros da pasta de cimento............................................................. 18

1.7.2 Alcalinidade do concreto e argamassa. Seus benefícios e prejuízos....................... 19

1.7.3 $\mathrm{O} \mathrm{pH} \mathrm{e} \mathrm{o} \mathrm{Ca}(\mathrm{OH})_{2}$ presentes nas argamassas de cimento Portland...................... 20

1.7.4 O mecanismo da reação pozolânica....................................................................... 20

\section{Argamassa Reforçada com Fibras}

$2.1 \quad$ Preâmbulos............................................................................................ 22

2.2 Alguns parâmetros relevantes no reforço de argamassas com fibras ....................... 22

2.3 Aplicações das argamassas e concretos reforçados com fibras.............................. 24

2.4 Propriedades mecânicas do concreto reforçado com fibras ..................................... 25

2.4.1 Resistência à compressão............................................................................... 25

2.4.2 Interação fibra-matriz................................................................................. 25

2.4.3 Fenômeno de grampeamento de fissuras .......................................................... 27

2.4.4 Resistência à tração e flexão ............................................................................ 27

2.5 A utilização das fibras de vidro em argamassa e concreto ..................................... 28

2.5.1 A fibra de vidro comum............................................................................. 28

2.5.2 Fibra de vidro álcali resistente ...................................................................... 29

2.5.3 O tratamento da superfície das fibras.............................................................. 31

2.5.4 Matriz de cimento com adições ......................................................................... 32

2.5.5 A modificação da matriz de cimento com látex........................................................ 34

2.5.6 Carbonatação da argamassa ou concreto............................................................. 35

2.5.7 Resumo das possíveis soluções para controle do ataque alcalino às fibras de vidro 36 Argamassa modificada com polímero

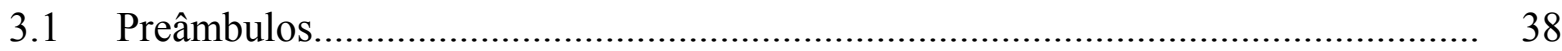

3.2 Noções Gerais sobre Polímeros....................................................................... 38

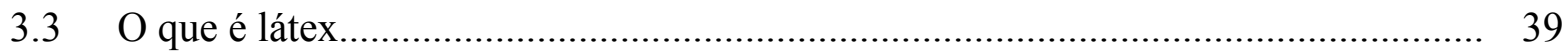

3.4 Utilização de polímeros em argamassas e concretos............................................... 41

3.5 Processo de formação do concreto e argamassa modificados com Látex.................. 42

3.6 Principais propriedades do concreto e argamassa modificados com látex.................. 45

3.7 Cura da argamassa modificada com látex............................................................. 46

\section{Metodologia}

4.1 Planejamento Experimental. 
4.1.1 Objetivo.

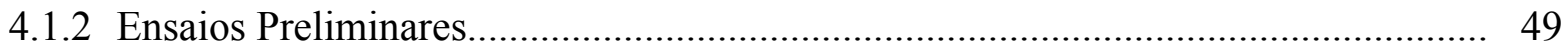

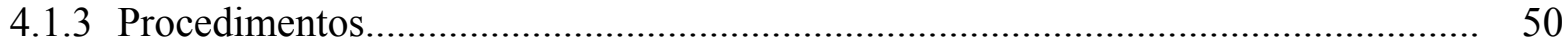

4.2 Características dos materiais utilizados.............................................................. 52

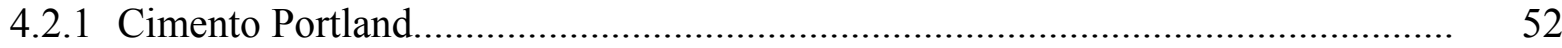

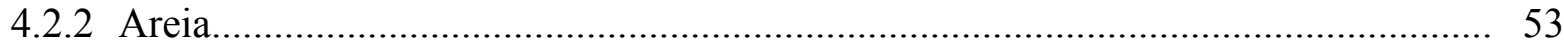

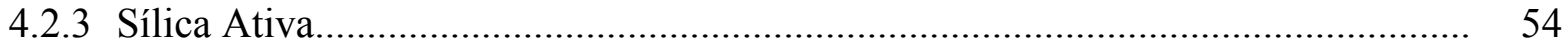

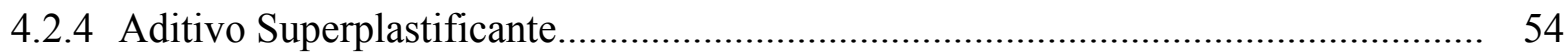

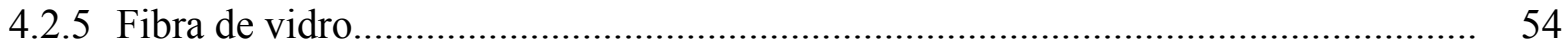

4.2.6 Látex Estireno-Butadieno (SB),_.................................................................. 55

4.3 Preparação dos corpos-de-prova ..................................................................... 55

4.3.1 Corpos-de-prova cilíndricos .......................................................................... 55

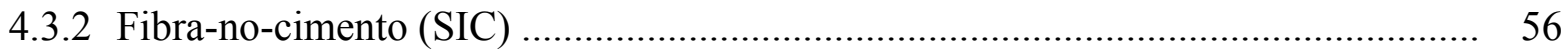

4.3.3 Corpos-de-prova para ensaio à flexão ................................................................ 58

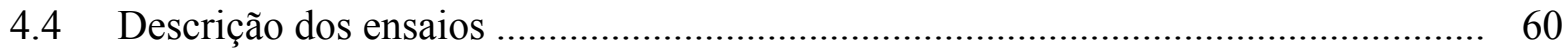

4.4.1 Ensaio à compressão axial e tração na compressão diametral ................................ 60

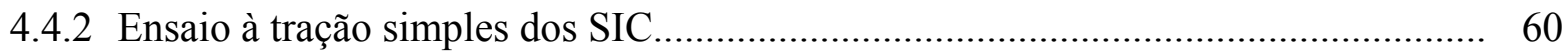

4.4.3 Ensaio à Flexão das Placas delgadas ........................................................................ 61

4.5 Processo de Hidratação Acelerado.............................................................................. 63

4.6 Depuração estatística dos resultados................................................................... 64

Resultados Experimentais

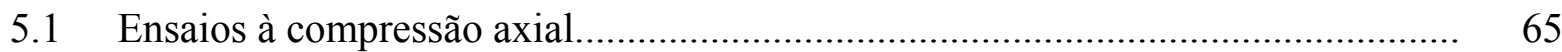

5.2 Ensaios à tração na compressão diametral............................................................ 66

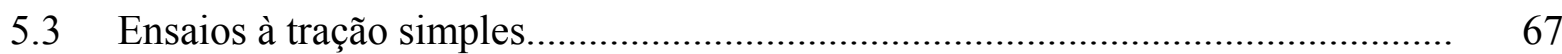

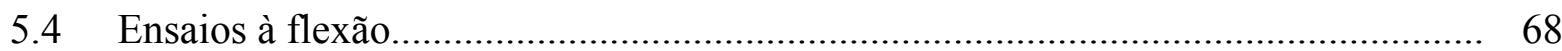

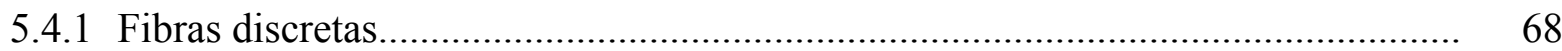

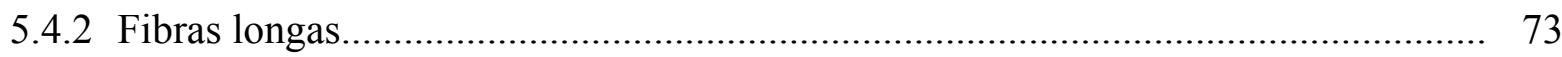

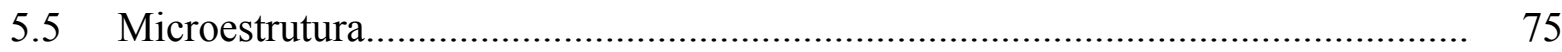

Análise dos resultados

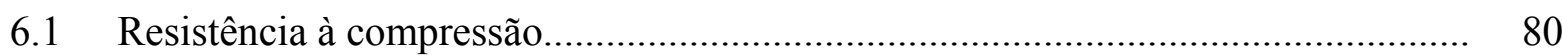

6.2 Resistência à tração na compressão diametral..................................................... 80

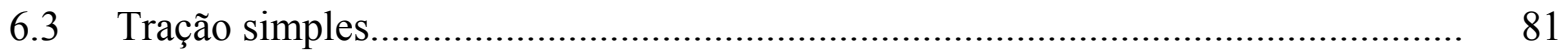

6.4 Módulo de ruptura à flexão..................................................................... 81

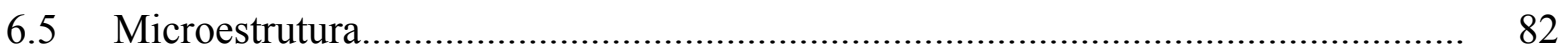


Conclusões $\quad 84$

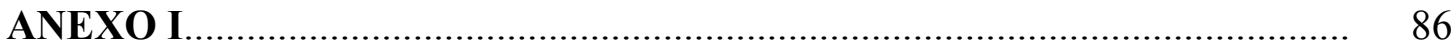

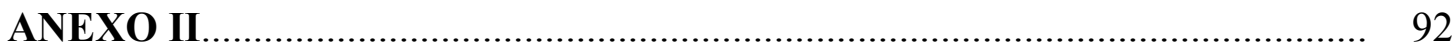

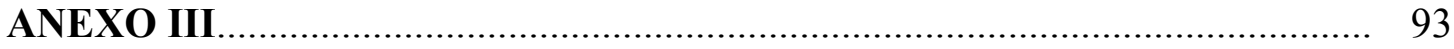

Referências Bibliográficas........................................................................ 95 


\section{LISTA DE FIGURAS}

FIGURA A Representação esquemática do comportamento à flexão de um concreto convencional e um CRF

FIGURA B Comportamento carga-flexão dos concretos convencionais e CRF 02

FIGURA 2.1 Interação fibra-matriz com a matriz não fissurada 26

FIGURA 2.2 Representação esquemática do processo de grampeamento de fissuras pelas fibras

FIGURA 2.3 Fibra de vidro AR em matriz de cimento Portland comum sem adições com processo de hidratação convencional

FIGURA 2.4 Fibra de vidro AR em matriz de cimento Portland comum sem adições com processo de hidratação acelerado de 56 dias à $65^{\circ} \mathrm{C}$

FIGURA 2.5 Efeito da adição de sílica ativa na argamassa e tratamento da superfície da fibra com sílica ativa

FIGURA 2.6 Efeito da modificação da argamassa com látex acrílico, com adição de sílica ativa e tratamento da superfície da fibra com látex acrílico

FIGURA 2.7 Fluxograma das possíveis soluções para controle do ataque alcalino do cimento Portland às fibras de vidro

FIGURA 3.1 Látex para utilização em concreto de cimento e polímero 40

FIGURA 3.2 Modelo idealizado de formação do concreto de cimento polímero

FIGURA 3.3 Modelo idealizado do processo de formação do filme de polímero na partícula de cimento hidratado

FIGURA 4.1 Curva granulométrica da areia utilizada 53

FIGURA 4.2 Representação esquemática do SIC utilizado na pesquisa 57

FIGURA 4.3 Fotografia dos SIC utilizados na pesquisa 57

FIGURA 4.4 Fotos de moldagem das placas para ensaio à flexão 58

FIGURA 4.5 Placas de compósito reforçadas com fibras contínuas 59

FIGURA 4.6 Fotos ensaio à compressão axial $\quad 60$

FIGURA 4.7 SIC sendo ensaiado à tração simples $\quad 61$

FIGURA 4.8 Representação esquemática do ensaio de flexão 61

FIGURA 4.9 Fotos do equipamento de ensaio à flexão $\quad 62$

FIGURA 4.10 Representação da curva força x deflexão segundo ASTM C 947/89 62 
FIGURA 5.1 Resistência à compressão axial das amostras de compósito padrão, modificadas e adição de sílica ativa

FIGURA 5.2 Diferença percentual dos valores de resistência à compressão

FIGURA 5.3 Resistência à tração na compressão diametral das amostras de compósito padrão, modificadas e com adição de sílica ativa

FIGURA 5.4 Diferença percentual dos valores de resistência à tração na compressão diametral

FIGURA 5.5 Carga de ruptura à tração simples do roving para os SIC's

FIGURA 5.6 Diferença percentual dos valores do módulo de ruptura à tração 68 simples

FIGURA 5.7 Valores de módulo de ruptura à flexão para argamassas de CP III sem adição de fibras curtas

FIGURA 5.8 Módulo re ruptura à flexão para argamassas de CP III e CP V ARI

FIGURA 5.9 Diferença percentual dos valores do módulo de ruptura à flexão das amostras de compósito padrão, modificadas e com adição de sílica ativa, entre processo de hidratação convencional e acelerado

FIGURA 5.10 Curvas carga $\mathrm{x}$ deslocamento para placas esbeltas com compósitos CP III padrão para o processo de hidratação convencional e acelerado

FIGURA 5.11 Curvas carga $\mathrm{x}$ deslocamento para placas esbeltas com compósitos CP III modificados com látex e com adição de sílica ativa para o processo de hidratação convencional e acelerado

FIGURA 5.12 Curvas carga $\mathrm{x}$ deslocamento para placas esbeltas com compósitos CP V ARI modificados com látex e com adição de sílica ativa para o processo de hidratação convencional e acelerado

FIGURA 5.13 Módulo re ruptura das fibras contínuas com proteção superficial comparadas àquelas sem proteção para o processo de hidratação convencional e acelerado

FIGURA 5.14 Diferença percentual dos valores do módulo de ruptura à flexão das amostras reforçadas com fibra de vidro contínua com e sem proteção superficial para o processo de hidratação convencional e acelerado

FIGURA 5.15 Curvas de carga x deslocamento para placas esbeltas com compósito padrão CP V ARI reforçada com fibras contínuas sem proteção superficial, com proteção superficial de látex SB e com proteção superficial de látex $\mathrm{SB}+$ sílica ativa

FIGURA 5.16 Microscopia Óptica (50x) da fibra de vidro do compósito padrão CP III após processo de hidratação convencional

FIGURA 5.17 Microscopia Óptica (50x) da fibra de vidro do compósito CP III 
modificado com látex após processo de hidratação acelerado

FIGURA 5.18 Microscopia Óptica (50x) da fibra de vidro do compósito CP III com adição de S.A. após processo de hidratação acelerado

FIGURA 5.19 Microscopia Óptica (50x) da fibra de vidro do compósito CP III modificado com látex com adição de S.A. após processo de 77 hidratação acelerado

FIGURA 5.20 Microscopia Óptica (50x) da fibra de vidro do compósito CP V ARI modificado com látex após processo de hidratação acelerado

FIGURA 5.21 Microscopia Óptica (50x) da fibra de vidro do compósito CP V ARI modificado com látex após processo de hidratação acelerado

FIGURA 5.22 Microscopia Óptica (50x) da fibra de vidro do compósito CP V ARI modificado com látex e adição de sílica ativa após processo de hidratação acelerado

FIGURA I . 1 Representação esquemática do tronco de cone para ensaio de "mini slump"

FIGURA I. 2 Seqüência de fotos mostrando o ensaio do Tronco de Cone 86

FIGURA I. 3 Curva de sensibilidade à água do cimento CP II E e CP II E + sílica 88 ativa

FIGURA I . 4 Curva de sensibilidade à água do cimento CP III e CP III + sílica 89 ativa

FIGURA I . 5 Curva de sensibilidade à água do cimento CP V ARI e CP V ARI + 89 sílica ativa

FIGURA I . 6 Área de espalhamento da pasta de cimento CP II E e CP II E + sílica ativa para vários teores de SP 1 com relação água/aglomerante fixada 90 em 0,36

FIGURA I . 7 Área de espalhamento da pasta de cimento CP II E e CP II E + sílica ativa para vários teores de SP 2 com relação água/aglomerante fixada 90 em 0,36

FIGURA I . 8 Área de espalhamento da pasta de cimento CP V ARI e CP V ARI + sílica ativa para vários teores de SP 2 com relação água/aglomerante fixada em 0,36

FIGURA II . 1 Índice de consistência para argamassas de CP II E 32 com adição de fibra de vidro discreta

FIGURA III. 1 Resistência à compressão axial das amostras de CP II E 32 dos ensaios preliminares 


\section{LISTA DE TABELAS}

TABELA 1 1 Óxidos compostos do clínquer e suas abreviações 10

TABELA 1.2 Propriedades dos principais componentes do cimento

TABELA 1.3 Composição do cimento Portland comum e cimento Portland 13 composto

TABELA 1.4 Composição do cimento Portland de alto forno e pozolânico 13

TABELA 1.5 Composição do Cimento de alta resistência inicial 14

TABELA 1.6 Principais características dos produtos de hidratação co cimento 15 Portland

TABELA 1.7 Resumo das principais propriedades físicas da sílica ativa 18

TABELA 2.1 Algumas propriedades da matriz de cimento Portland comum 23

TABELA 2.2 Algumas características e propriedades mecânicas e químicas das 24 fibras

TABELA 3.1 Propriedades de alguns látex polímeros 41

TABELA 3.2 Principais propriedades do concreto e argamassa modificados com 46 polímero no estado fresco e endurecido

TABELA 4.1 Características dos cimentos utilizados 52

TABELA 4.2 Análise química dos cimentos (\%) 53

TABELA 4.3 Determinação da Composição Granulométrica da Areia 53

TABELA 4.4 Determinação da Composição Granulométrica da Areia 54

TABELA 4.5 Propriedades e características dos aditivos superplastificantes $\quad 54$

TABELA 4.6 Composição da fibra de vidro 54

TABELA 4.7 Propriedades do látex Estireno-butadieno 55

TABELA 4.8 Composição dos compósitos padrão para ensaios com corpos-deprova cilíndricos

TABELA 4.9 Composição dos compósitos modificados e com adição de S.A. para corpos de prova cilíndricos

TABELA 4.10 Composição dos compósitos padrão para os SIC 57

TABELA 4.11 Composição das argamassas modificadas para os SIC 58

TABELA III . 1 Composição dos compósitos dos ensaios preliminares 93 


\section{LISTA DE SIMBOLOS}

b Largura média do corpo-de-prova na seção de ruptura

d Diâmetro do corpo-de-prova

F Carga máxima aplicada

1 Distância entre cutelos de suporte

P Carga de ruptura 


\section{LISTA DE ABREVIATURAS E SIGLAS}
A $\quad \mathrm{Al}_{2} \mathrm{O}_{3}$
ABNT Associação Brasileira de Normas Tecnicas
a/c Relação água/cimento
ACI American Concrete Institute
AR Álcali-Resistente
ASTM American Society for Testing and Materials
C $\quad \mathrm{CaO}$
$\mathrm{CH} \quad \mathrm{Ca}(\mathrm{OH})_{2}$
CRF Concreto Reforçado com Fibras
C-S-H Silicato de cálcio hidratado de composição não especificada
DRX Difração de raios X
GRC Matriz cimentícia reforçada com fibras de vidro
$\mathrm{H} \quad \mathrm{H}_{2} \mathrm{O}$
K $\quad \mathrm{K}_{2} \mathrm{O}$
$\mathrm{M} \quad \mathrm{MgO}$
$\mathrm{N} \quad \mathrm{NaO}$
S $\quad \mathrm{SiO}_{2}$ 


\section{Resumo}

\section{PERUZZI, A. P. (2002). Comportamento das fibras de vidro convencionais em matriz de cimento Portland modificada com látex e adição de sílica ativa. São Carlos, 2002. 96 p. Dissertação (Mestrado) - Escola de Engenharia de São Carlos, Universidade de São Paulo}

As argamassas e concretos de cimento Portland são materiais de construção duráveis, relativamente baratos que, embora apresentem boa rigidez e adequada resistência à compressão, têm outras propriedades deficientes, tais como: resistência à tração, ao impacto, à fadiga, além de baixa tenacidade e ductilidade. Uma considerável melhora destas propriedades pode ser obtida com adição de fibras, em quantidades adequadas, na composição destes materiais. A utilização de fibra de vidro convencional (tipo E) no reforço das argamassas de cimento Portland, pode ser viável uma vez contornado o ataque do meio alcalino à fibra, principalmente o hidróxido de cálcio $\mathrm{Ca}(\mathrm{OH})_{2}$, produzido na hidratação do cimento. No presente trabalho foi obtida uma menor intensidade de ataque alcalino às fibras de vidro $\mathrm{E}$, por meio da modificação com látex Estireno Butadieno, da adição de sílica ativa em substituição ao cimento Portland e da utilização de ambos concomitantemente. Outro procedimento utilizado, visando uma maior durabilidade das fibras de vidro, foi a proteção da superfície desta fibra com uma película de látex Estireno Butadieno e de uma mistura deste látex e sílica ativa. A eficiência de um e outro procedimento foi verificada por meio da comparação dos resultados de ensaio à tração e flexão, em amostras submetidas a processo de hidratação convencional e acelerado e observações pro meio de microscopia óptica.

\footnotetext{
Palavras-chave: Fibra/ Alcalinidade/ GRC/ Corrosão/ Dry wall / Eglass
} 
PERUZZI, A. P. (2002). Behavior of conventional glass fibers in matrix of Portland cement modified with latex and with the addition of silica fume. São Carlos, 2002. 96 p. Master thesis - São Carlos School of Engineering. São Paulo University.

Portland cement mortar and concrete are durable building materials, relatively cheap and, despite they display a good rigidity and an adequate compressive strength, they have other deficient properties such as tensile strength, impact, fatigue, beyond low toughness and ductility. A considerable improvement of these properties can be obtained adding fibers, in adequate quantities, in the composition of the materials. The use of conventional glass fiber (E-glass) in the reinforcement of Portland cement mortar can be possible if the attack of the alkaline environment, produced by cement hydration (chiefly by calcium hydroxide), to the fiber is controlled. In this work, a lesser intensity of alkaline attack on the E-glass fibers was succeded through the modification of the Portland cement matrix by styrene butadiene latex, the addition of silica fume or through the utilization of both additives at the same time. Another proceeding, aiming at a greater durability of the E-glass, has been the protection of the fiber surface with a styrene butadiene latex coating or with a mixture of this same latex and silica fume. The efficiency of each proceeding was verified by the comparison of tensile strength and flexural strength in samples submitted to accelerate and conventional hydration processes and by the observation of the interface glass/matrix with optical microscopy.

Keywords: Fibre/ alkalinity/GRC/ corrosion/ Dry wall/ Eglass 


\section{Introdução}

\section{A. Generalidades}

A argamassa de cimento Portland é um material de construção durável, barato e dotado de adequada resistência à compressão e rigidez, entretanto, apresenta ruptura frágil, baixa resistência à tração e pequena capacidade de deformação. Uma maneira eficiente de conferir a essas argamassas maior resistência à tração, ao impacto e à fadiga, além de tenacidade e ductilidade, é a adição de fibras curtas à mistura. (TEZUKA, 1989)

As Figuras A e $\mathbf{B}$ apresentam, respectivamente, a diferença de ruptura à flexão de um concreto ${ }^{1}$ sem o reforço de fibras e com fibras e o comportamento carga - deflexão de concretos convencionais e concretos reforçados com fibras (CRF).

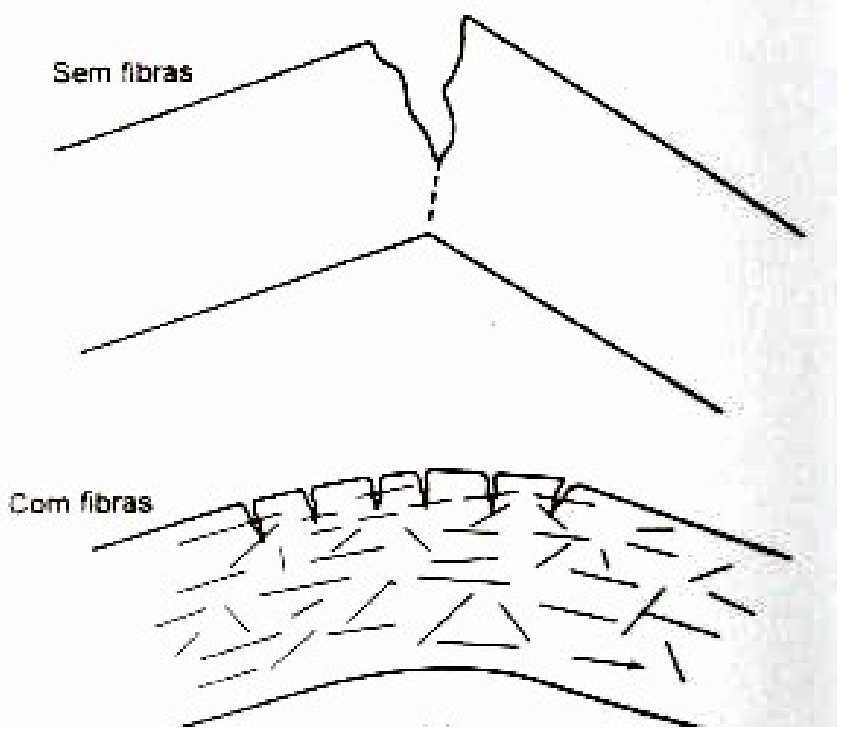

FIGURA A - Representação esquemática do comportamento à flexão de um concreto convencional e um CRF (MEHTA \& MONTEIRO, 1994)

\footnotetext{
${ }^{1}$ Nesta dissertação, considera-se a argamassa utilizada como sendo um concreto sem agregados graúdos. Por isso, algumas vezes, certas características e propriedades do concreto são tomadas como válidas para as argamassas.
} 


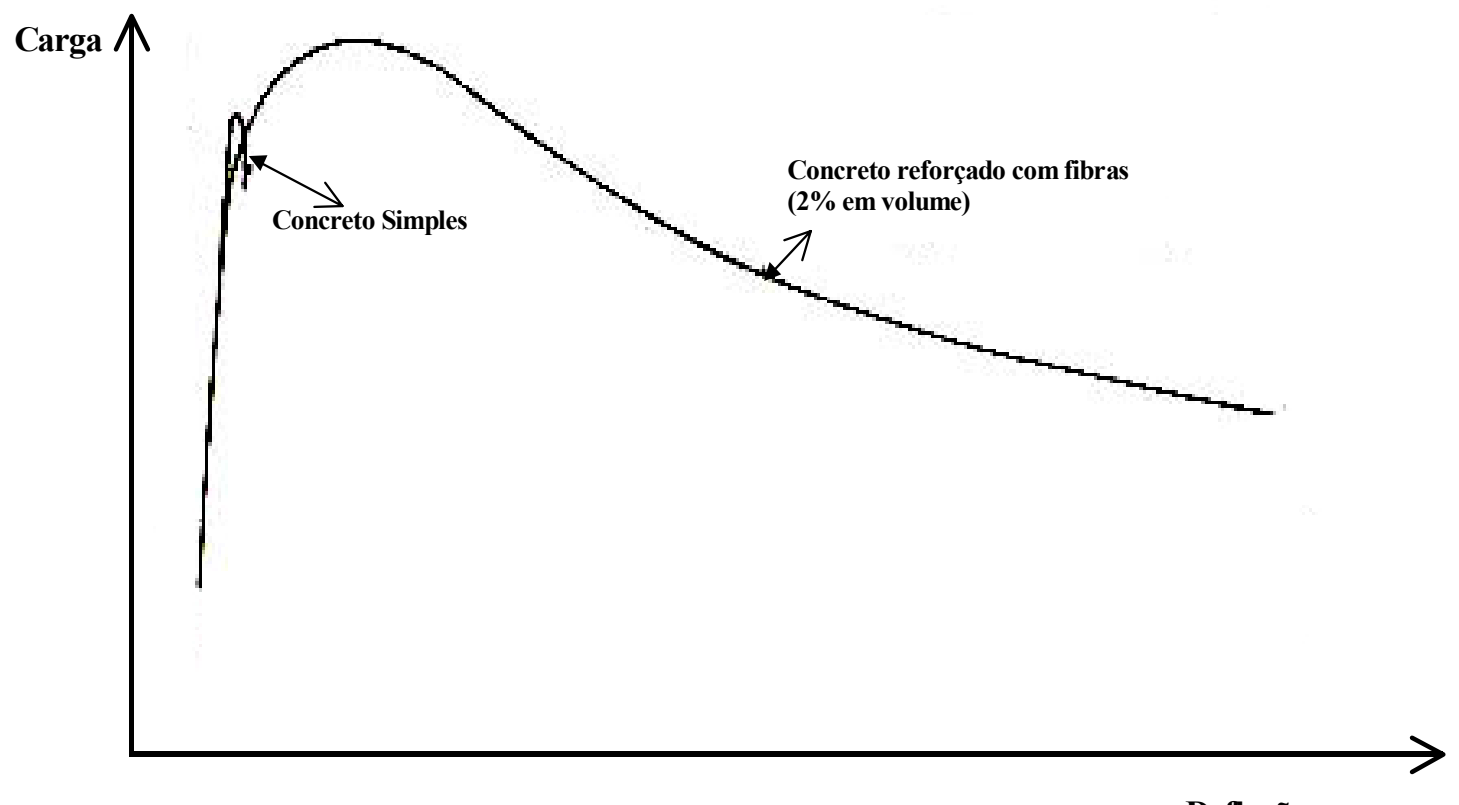

Figura B - Comportamento carga - deflexão dos concretos convencionais e CRF (MEHTA \& MONTEIRO, 1994)

\section{B. Aplicações}

O compósito ${ }^{2}$ objeto do presente estudo tem como finalidade a aplicação industrial na produção de componentes esbeltos, tais como:

- placas no sistema dry wall

- dutos e shafts para instalações de rede elétrica, cabos de fibra ótica, fôrmas permanentes para concreto, etc.;

- elementos de fibrocimento, em substituição ao amianto ${ }^{3}$.

No estado fresco, esses compósitos devem apresentar trabalhabilidade que possibilite a moldagem de acordo com cada tipo de elemento que se deseja obter, além de oferecer as resistências químicas e físicas esperadas para cada tipo de aplicação. No estado endurecido, devem diminuir a fragilidade dos elementos esbeltos feitos de cimento Portland, conferindo tenacidade e ductilidade a eles.

\footnotetext{
${ }^{2}$ Entende-se por compósito um material formado por uma certa quantidade de fibras, embebidas em uma fase contínua, chamada matriz.

${ }^{3}$ A utilização do amianto está em processo de proibição no Brasil, acompanhando uma tendência mundial.
} 


\section{Características mecânicas desejáveis}

A tenacidade e a ductilidade são duas propriedades muito importantes para os elementos esbeltos utilizados na construção civil, pois facilitam o manuseio, tanto na fase de produção e transporte quanto na instalação, minimizando sua fissuração, ou até mesmo evitando sua quebra.

Segundo OLIVEIRA (1995), as fibras ampliam a capacidade de deformação do material e aumentam a sua capacidade de suporte de carga, principalmente quando submetida a esforços de tração, flexo-tração e impacto.

Essa maior capacidade de deformação é obtida pelo efeito de grampeamento das fissuras, por meio do atrito e da aderência existente entre as fibras e a matriz de cimento. Assim, substituem-se fissuras pronunciadas, chamadas de macrofissuras (característica encontrada nas argamassas de cimento Portland sem adição de fibras), por inúmeras microfissuras, de menor abertura e em maior número.

\section{Limitações da fibra de vidro e possíveis maneiras de contornar suas deficiências}

Entre os diversos tipos de materiais utilizados para o reforço de argamassas de cimento Portland, tais como as fibras de aço, náilon, carbono, vegetais, está a fibra de vidro. A fibra de vidro convencional, tipo E, sofre degradação das propriedades físicas com o tempo, devido ao ataque do meio alcalino da matriz de cimento Portland, o que afeta, principalmente, a tenacidade, diminuindo progressivamente sua flexibilidade, tornando-a frágil.

Segundo PURNELL et al (2000), essa baixa durabilidade das fibras de vidro convencionais em concretos de cimento Portland (GRC) é, geralmente, atribuída a um ou mais destes mecanismos:

1) corrosão das fibras pelo hidróxido de cálcio $\left(\mathrm{Ca}(\mathrm{OH})_{2}\right)$ produzido na hidratação do cimento Portland;

2) precipitação dos produtos da hidratação, especialmente do $\mathrm{Ca}(\mathrm{OH})_{2}$;

3) densificação da matriz na interface reduzindo a flexibilidade das fibras.

Para contornar a degradação das fibras de vidro, PURNELL et al (2000) citam as seguintes possibilidades: 
1) melhorar a resistência das fibras, por meio do uso de fibra de vidro álcalis-resistente (AR) ou do preparo de sua superfície para resistir ao ataque;

2) modificar as matrizes de cimento das seguintes maneiras:

a) utilizar cimentos de baixa alcalinidade, como o cimento de alto forno (CP III);

b) adicionar sílica ativa, cinza volante, metacaulinita e outros materiais, que têm por objetivo baixar o $\mathrm{pH}$ da solução dos poros e/ou reduzir ou eliminar a formação de hidróxido de cálcio.

A fibra de vidro álcalis-resistente (AR), foi desenvolvida, nos últimos anos, pela presença de cerca de $16 \%$ de óxido de zircônio $\left(\mathrm{ZrO}_{2}\right)$ na composição do vidro (TEZUKA, 1989; PARDELA e AGUILA, 1998), apresentando melhor desempenho em relação à durabilidade em meios alcalinos, se comparada à fibra de vidro convencional.

O custo da fibra de vidro AR é alto, cerca de três vezes o valor da fibra convencional, sendo economicamente interessante viabilizar a utilização da fibra de vidro convencional em argamassas de cimento Portland. Para tanto, é necessário proteger as fibras do ataque químico do meio alcalino do cimento Portland, por meio da modificação das argamassas com látex, da adição de sílica ativa ou, ainda, da proteção superficial destas fibras.

\section{E. Formulação da situação-problema}

Hidratação da Alita $\left(3 \mathrm{CaO} . \mathrm{SiO}_{2}\right.$ representado por $\left.\mathrm{C}_{3} \mathrm{~S}\right){ }^{(*)}$

$2 \mathrm{C}_{\mathbf{3}} \mathrm{S}+6 \mathrm{H} \rightarrow \mathrm{C}_{\mathbf{3}}-\mathrm{S}_{\mathbf{2}}-\mathrm{H}_{\mathbf{3}}+3 \mathrm{CH}^{\text {Portlandita }}$

$2\left(3 \mathrm{CaO} . \mathrm{SiO}_{2}\right)+6 \mathrm{H}_{2} \mathrm{O} \rightarrow 3 \mathrm{CaO} .2 \mathrm{SiO}_{2} \cdot 3 \mathrm{H}_{2} \mathrm{O}+3 \mathrm{Ca}(\mathrm{OH})_{2}$

\section{Hidratação da Belita $\left(2 \mathrm{CaO} \mathrm{SiO}_{2}\right.$ representado pelo $\left.\mathrm{C}_{2} \mathrm{~S}\right)$}

$2 \mathrm{C}_{2} \mathrm{~S}+4 \mathrm{H} \rightarrow \mathrm{C}_{3}-\mathrm{S}_{2}-\mathrm{H}_{3}+\mathrm{CH}^{\text {Portlandita }}$

$2\left(2 \mathrm{CaO} . \mathrm{SiO}_{2}\right)+4 \mathrm{H}_{2} \mathrm{O} \rightarrow 3 \mathrm{CaO} .2 \mathrm{SiO}_{2} \cdot 3 \mathrm{H}_{2} \mathrm{O}+\mathrm{Ca}(\mathrm{OH})_{2}$

${ }^{(*)}$ Essas reações podem ser escritas supondo-se que o $\mathrm{C}_{3} \mathrm{~S}_{2} \mathrm{H}_{3}$ seja o produto final da hidratação do $\mathrm{C}_{3} \mathrm{~S}$ e do $\mathrm{C}_{2} \mathrm{~S}$ (NEVILLE, 1997)

O hidróxido de cálcio $\mathrm{Ca}(\mathrm{OH})_{2}$ conhecido como Portlandita e denotado como $\mathrm{CH}$, produzido concomitantemente com o silicato hidratado de cálcio, é o maior 
responsável pelo meio alcalino que reage com as fibras de vidro, causando a perda de resistência mecânica. Nas reações de hidratação apresentadas acima, é possível notar que a reação de hidratação da Alita $\left(\mathrm{C}_{3} \mathrm{~S}\right)$ produz três vezes mais hidróxido de cálcio que a hidratação da Belita $\left(\mathrm{C}_{2} \mathrm{~S}\right)$, de tal forma que a utilização de um cimento com maior teor de $\mathrm{C}_{3} \mathrm{~S}$ (CP V ARI por exemplo) favorece a maior formação de Portlandita, se comparado a um cimento com maior teor de $\mathrm{C}_{2} \mathrm{~S}$ (CP II E e CP III, por exemplo).

No desenvolvimento desse trabalho, utilizou-se três tipos de cimento:

- CP V ARI, que representa o cimento mais desfavorável para a fibra de vidro, sob o ponto de vista do ataque alcalino às fibras;

- CP III, que contém grande quantidade de escória granulada de alto forno, cerca de $35 \%$ a $70 \%$, em substituição ao clínquer. Com isso, a quantidade de Portlandita produzida é menor e representa o cimento mais favorável para a fibra de vidro, sob o ponto de vista do ataque alcalino à mesma;

- CP II E, que contém de $6 \%$ a $34 \%$ de escória granulada de alto forno em substituição ao clínquer, representando o caso intermediário entre o $\mathbf{C P} \mathbf{V}$ ARI e o CP III.

A fibra de vidro utilizada na pesquisa objeto desta dissertação foi fornecida pela Owens Corning e tem quase $60 \%$ de sua composição formada por Si $\mathrm{O}_{2}$. Assim, uma maior a durabilidade dos compósitos de cimento Portland reforçados com esta fibra será possível, se uma menor quantidade de $\mathrm{Ca}(\mathrm{OH})_{2}$ estiver livre na matriz para reagir com a sílica da fibra.

A utilização de cimentos contendo escória granulada de alto forno, tais como o CP II E e o CP III, é uma maneira de diminuir a quantidade de $\mathrm{Ca}(\mathrm{OH})_{2}$ na matriz, pois essa escória finamente moída, adicionada ao cimento Portland, substitui parte do clínquer no cimento, minorando a quantidade de $\mathrm{Ca}(\mathrm{OH})_{2}$ produzido.

Uma segunda maneira de diminuir a quantidade de $\mathrm{Ca}(\mathrm{OH})_{2}$ na matriz é por meio da modificação da argamassa com polímero, pois:

1) Segundo BIJEN (1993), o polímero diminui o espaço disponível dentro da pasta de cimento para o transporte dos íons pela água contida nos poros; 
2) AFRIDI et al. (1989) consideram que a modificação por meio de látex reduz a formação de $\mathrm{Ca}(\mathrm{OH})_{2}$, possivelmente devido à adsorção de $\mathrm{Ca}(\mathrm{OH})_{2}$ nos filmes de polímero, os quais diminuem a quantidade de íons e o espaço disponível entre os grãos hidratados de cimento, dificultando o transporte dos íons através dos poros e capilares.

A terceira maneira de proteger a fibra do ataque do meio alcalino é adicionando-se sílica ativa ao compósito, que atuará no consumo de $\mathrm{Ca}(\mathrm{OH})_{2}$, por meio da reação pozolânica. Outra maneira eficiente de atenuar a corrosão química das fibras de vidro pelos produtos da hidratação do cimento Portland é a proteção da superfície desta fibra, por meio da aplicação do látex ou de uma mistura de látex e sílica ativa.

Ao contrário das três primeiras maneiras, pelas quais se deseja diminuir a quantidade de $\mathrm{Ca}(\mathrm{OH})_{2}$, o quarto procedimento (proteção superficial da fibra) tem por objetivo proporcionar um encapsulamento à fibra, impedindo o contato desta com os produtos da hidratação.

\section{F. Objetivos}

O objetivo da pesquisa foi estudar a compatibilidade do uso de fibras de vidro convencionais em argamassas de cimento Portland por meio de dois processos distintos:

$\left.1^{\circ}\right)$ modificação da argamassa de cimento Portland com látex EstirenoButadieno (SB) e adição de sílica ativa;

$2^{\circ}$ ) realização de uma prévia proteção da superfície da fibra, por meio da imersão desta em látex ou em uma mistura látex e sílica ativa.

\section{G. Apresentação da dissertação}

O capítulo 1 trata da matéria prima utilizada para a fabricação do cimento Portland, seus componentes e os produtos de sua hidratação. A seguir, são apresentados os principais tipos de cimentos produzidos comercialmente no Brasil e sua composição. Trata-se de um assunto relevante para os objetivos do trabalho, pois, como já foi visto, o problema do ataque do meio alcalino do cimento Portland às fibras de vidro é causado, principalmente, pelo hidróxido de cálcio $\mathrm{Ca}(\mathrm{OH})_{2}$, que é um dos 
produtos da hidratação. Ainda nesse capítulo, é discutida a possibilidade de se promover o controle desse ataque às fibras.

O capítulo 2 apresenta o reforço de argamassas e concretos com fibras de diversos tipos, abordando a influência que a adição das fibras exerce nas propriedades mecânicas destes. É apresentada a fibra de vidro para este reforço e analisado o problema que o meio alcalino do cimento Portland representa à perda de resistência mecânica das fibras tipo E e AR.

No capítulo 3, é estudada a modificação da argamassa de cimento Portland com o látex, iniciando por uma breve abordagem sobre polímero, sua obtenção e classificação. A seguir, são apresentados os estudos de diversos autores relacionado à argamassa modificada com látex, suas propriedades mecânicas e químicas e seu processo de hidratação, além do processo de cura indicado.

No capítulo 4, são apresentados o planejamento experimental, os materiais e os métodos utilizados na execução dos ensaios.

O capítulo 5 apresenta os resultados experimentais.

O capítulo 6 apresenta uma análise dos resultados, conclusões e perspectivas. 
CAPítulo

Cimento Portland

\subsection{A fabricação}

O cimento Portland é constituído principalmente de material calcário, como rocha calcária ou gesso, alumina e sílica, encontrados em argilas e xisto. As argilas também contêm alumina $\left(\mathrm{Al}_{2} \mathrm{O}_{3}\right)$ e, freqüentemente, óxidos de ferro $\left(\mathrm{Fe}_{2} \mathrm{O}_{3}\right)$ e álcalis. A presença de $\mathrm{Al}_{2} \mathrm{O}_{3}, \mathrm{Fe}_{2} \mathrm{O}_{3}, \mathrm{MgO}$ e álcalis na mistura de matérias primas tem efeito mineralizante na formação de silicatos de cálcio. Quando não estão presentes quantidades suficientes de $\mathrm{Al}_{2} \mathrm{O}_{3}$ e $\mathrm{Fe}_{2} \mathrm{O}_{3}$ nas matérias primas principais, estes são propositalmente incorporados à mistura por adição de materiais secundários, como a bauxita e o minério de ferro. (MEHTA \& MONTEIRO, 1994)

Após a extração da matéria prima, a moagem e a mistura desse material, são realizados ajustes para obter a composição química pretendida. A seguir, a mistura é levada a um grande cilindro revestido de material refratário, com até $8 \mathrm{~m}$ de diâmetro, que chega a 230 metros de comprimento, girando lentamente em torno do eixo que está ligeiramente inclinado em relação à horizontal. A mistura, no seu movimento forno abaixo, encontra temperaturas progressivamente mais elevadas, liberando-se inicialmente a água e o $\mathrm{CO}_{2}$; em seguida, o material seco sofre uma série de reações químicas até que, finalmente, na parte mais quente do forno, cerca de $20 \%$ a 30\% do material se funde e o calcário, a sílica e a alumina se recombinam. A massa se funde em pelotas com diâmetro de $3 \mathrm{~mm}$ e $25 \mathrm{~mm}$, conhecidas como clínquer e são resfriadas. Após a adição de gesso e das adições minerais desejadas, ocorre a moagem, outra etapa bastante importante, pois, dependendo da finura em que os componentes são moídos, o cimento necessitará de mais ou menos água para se obter a plasticidade desejada do concreto, maior ou menor será o calor de hidratação, etc. (NEVILLE, 1997) 


\subsection{Importância de cada fase na qualidade final dos cimentos}

Em relação à extração e britagem da matéria prima (calcário e argila), o material deve ser extraído de uma jazida de boa qualidade e britado em britadores cujas mandíbulas estejam em bom estado, garantindo uma britagem eficiente.

Por causa do alto custo da energia, os produtores de cimento têm usado a mistura via seca, que se trata de uma farinha crua, com umidade de 0,2\%. Antes de entrar no forno rotativo, essa farinha seca é pré aquecida até cerca de $800^{\circ} \mathrm{C}$. Essa temperatura é mantida estável para assegurar a calcinação uniforme e a eficiência da troca de calor. (NEVILLE, 1997)

Dentro do forno rotativo se dão as seguintes reações:

- $\mathrm{T}>800^{\circ} \mathrm{C}$ tem-se a formação do $\mathrm{C}_{2} \mathrm{~S}$, produtos intermediários, aluminatos e ferrita;

- $\mathrm{T}>1250^{\circ} \mathrm{C}$ tem-se a formação da fase líquida;

- T aprox. $1450{ }^{\circ} \mathrm{C}$ tem-se a formação do $\mathrm{C}_{3} \mathrm{~S}$ e $\mathrm{C}_{2} \mathrm{~S}$.

No resfriamento:

- entre $1300^{\circ} \mathrm{C}$ e $1240^{\circ} \mathrm{C}$ tem-se a cristalização da fase líquida, especialmente os aluminatos e a ferrita;

- entre $1240{ }^{\circ} \mathrm{C}$ e $150{ }^{\circ} \mathrm{C}$, ocorre a consolidação das características dos minerais obtidos no forno. (KATTAR \& ALMEIDA, 1999)

\subsection{Composição química do cimento Portland}

O cimento Portland consiste de vários compostos de cálcio, mas os resultados de análises químicas de rotina são expressos em termos de óxidos dos elementos presentes. Costuma-se expressar os compostos do clínquer usando-se as seguintes abreviações: 
Tabela 1.1 - Óxidos compostos do clínquer e suas abreviações (MEHTA \& MONTEIRO, 1994)

\begin{tabular}{cccc}
\hline Óxido & Abreviação & \multicolumn{1}{c}{ Compostos } & Abreviação \\
\hline $\mathbf{C a ~ O}$ & $\mathbf{C}$ & $3 \mathrm{CaO} \cdot \mathrm{SiO}_{2}$ & $\mathrm{C}_{3} \mathrm{~S}$ \\
\hline $\mathbf{S i O}_{2}$ & $\mathbf{S}$ & $2 \mathrm{CaO} \cdot \mathrm{SiO}_{2}$ & $\mathrm{C}_{2} \mathrm{~S}$ \\
\hline $\mathbf{A l}_{2} \mathbf{O}_{3}$ & $\mathbf{A}$ & $3 \mathrm{CaO} \cdot \mathrm{Al}_{2} \mathrm{O}_{3}$ & $\mathrm{C}_{3} \mathrm{~A}$ \\
\hline $\mathbf{F e}_{2} \mathbf{O}_{3}$ & $\mathbf{F}$ & $4 \mathrm{CaO} \cdot \mathrm{Al}_{2} \mathrm{O}_{3} \cdot \mathrm{Fe}_{2} \mathrm{O}_{3}$ & $\mathrm{C}_{4} \mathrm{AF}$ \\
\hline $\mathbf{M g O}$ & $\mathbf{M}$ & $4 \mathrm{CaO} \cdot 3 \mathrm{Al}_{2} \mathrm{O}_{3} \cdot \mathrm{SO}_{3}$ & $\mathrm{C}_{4} \mathrm{~A}_{3} \mathrm{~S}$ \\
\hline $\mathbf{S O} \mathbf{O}_{3}$ & $\mathbf{S}$ & $3 \mathrm{CaO} \cdot 2 \mathrm{SiO}_{2} \cdot 3 \mathrm{H}_{2} \mathrm{O}$ & $\mathrm{C}_{3} \mathrm{~S}_{2} \mathrm{H}_{3}$ \\
\hline $\mathbf{H}_{2} \mathbf{O}$ & $\mathbf{H}$ & $\mathrm{CaSO} \cdot 2 \mathrm{H}_{2} \mathrm{O}$ & $\mathrm{CSH}_{2}$ \\
\hline
\end{tabular}

Os constituintes fundamentais do cimento Portland são: a cal $(\mathrm{CaO})$, a sílica $\left(\mathrm{SiO}_{2}\right)$, a alumina $\left(\mathrm{Al}_{2} \mathrm{O}_{3}\right)$, o óxido de ferro $\left(\mathrm{Fe}_{2} \mathrm{O}_{3}\right)$, uma certa quantidade de magnésia $(\mathrm{MgO})$ e uma pequena porcentagem de anidrido sulfúrico $\left(\mathrm{SO}_{3}\right)$, que é adicionado após a calcinação para retardar o tempo de pega do produto, que são os componentes essenciais do cimento Portland.

Outros componentes estão presentes em menores quantidades, tais como: impurezas, óxido de sódio $\left(\mathrm{Na}_{2} \mathrm{O}\right)$, óxido de potássio $\left(\mathrm{K}_{2} \mathrm{O}\right)$, óxido de titânio $\left(\mathrm{TiO}_{2}\right)$ e outras substâncias de menor importância. Os óxidos de potássio e sódio constituem os denominados álcalis do cimento.

Os compostos principais do cimento Portland são:

\section{i) Silicato Tricálcico $\left(\mathrm{C}_{3} \mathrm{~S}\right)$}

Também conhecido como Alita, é normalmente preponderante, aparece como pequenos grãos eqüidimensionais incolores. Usualmente, $\mathrm{o}_{3} \mathrm{~S}$ comparece entre 60\% e 67\% na composição do cimento Portland. (NEVILLE, 1997)

A hidratação do $\mathrm{C}_{3} \mathrm{~S}$ inicia-se em poucas horas, apresenta um desprendimento de calor médio e é o maior responsável pela resistência mecânica nas primeiras idades nos concretos e argamassas.

ii) Beta Silicato dicálcico $\left(\beta \mathrm{C}_{2} \mathrm{~S}\right)$ 
Também conhecido como Belita, tem três ou, possivelmente, quatro formas. $\mathrm{O} \alpha-\mathbf{C}_{2} \mathbf{S}$ que existe a temperaturas elevadas, se transforma na forma de $\beta$ a cerca de $1450{ }^{\circ} \mathrm{C}$. O $\beta-\mathbf{C}_{2} \mathbf{S}$ sofre outra transformação para a forma de $\gamma-\mathbf{C}_{2} \mathbf{S}$ a cerca de $670{ }^{\circ} \mathrm{C}$ mas, à velocidade de resfriamento dos cimentos comerciais, o $\beta-\mathbf{C}_{2} \mathbf{S}$ se mantém no clínquer. $\mathrm{O} \beta-\mathbf{C}_{2} \mathbf{S}$ forma grãos arredondados, geralmente geminados. Usualmente, o $\mathrm{C}_{2} \mathrm{~S}$ comparece entre $17 \%$ e $25 \%$ na composição do cimento Portland. (NEVILLE, 1997)

A hidratação do $\mathrm{C}_{2} \mathrm{~S}$ ocorre lentamente, apresentando um desprendimento de calor baixo, sendo responsável pela resistência mecânica nas idades mais avançadas.

\section{iii) Aluminato de Cálcio $\left(\mathrm{C}_{3} \mathrm{~A}\right)$}

Conhecido como Aluminato, forma cristais retangulares, mas em fases vítreas congeladas, forma uma fase intersticial amorfa. Comparece entre 3\% e 8\% na composição do cimento Portland. (NEVILLE, 1997)

$\mathrm{A}$ hidratação do $\mathrm{C}_{3} \mathrm{~A}$ é extremamente rápida, cristalizando em poucos minutos, o que contribui especialmente para resistência mecânica ao primeiro dia; apresenta um desprendimento de calor elevado, mas não incrementa a resistência nas idades posteriores. $\mathrm{O}$ aluminato de cálcio, quando presente em forma cristalina, é o responsável pela rapidez da pega mas, com a adição de sulfato de cálcio, o tempo de hidratação é controlado.

\section{iv) Ferroaluminato de Cálcio $\left(\mathrm{C}_{4} \mathrm{AF}\right)$}

Conhecido como Ferrita, é na verdade uma solução sólida, cuja composição varia entre $\mathrm{C}_{2} \mathrm{~F}$ e $\mathrm{C}_{6} \mathrm{~A}_{2} \mathrm{~F}$, embora a descrição como $\mathrm{C}_{4} \mathrm{AF}$ apresente-se como uma simplificação cômoda. Comparece entre $0,5 \%$ e $0,6 \%$ na composição do cimento Portland. (NEVILLE, 1997)

$\mathrm{A}$ hidratação do $\mathrm{C}_{4} \mathrm{AF}$ é rápida, porém não tão intensa quanto o $\mathrm{C}_{3} \mathrm{~A}$; apresenta um desprendimento de calor médio, contribui muito pouco (ou nada) para a resistência mecânica nas primeiras idades.

\section{v) Demais Compostos}

As propriedades do cimento Portland são diretamente relacionadas às 
proporções dos silicatos e aluminatos, portanto, o $\mathrm{MgO}, \quad$ o $\mathrm{SO}_{3}$ e os álcalis comparecem em proporções de respectivamente, $0,5 \%$ a $4 \%, 2 \%$ a $3,5 \%$ e $0,3 \%$ a $1,2 \%$.

Baseado em KATTAR \& ALMEIDA (1999) e em NEVILLE (1997), pode-se resumir as propriedades dos principais componentes do cimento como o que é apresentado na Tabela 1.2.

TABELA 1. 2 - Propriedades dos principais componentes do cimento (KATTAR \& ALMEIDA (1999), NEVILLE (1997))

\begin{tabular}{ccccc}
\hline Propriedades & $\mathbf{C}_{3} \mathbf{S}$ & $\mathbf{C}_{2} \mathbf{S}$ & $\mathbf{C}_{3} \mathbf{A}$ & $\mathbf{C}_{4} \mathbf{A F}$ \\
\hline Resistência em pequenas idades & Alta & Fraca & Boa & Fraca \\
Resistência em idades posteriores & Boa & Boa & Fraca & Fraca \\
Velocidade de hidratação & Média & Lenta & Rápida & Rápida \\
Liberação de calor durante a hidratação & Média & Pequena & Grande & Média \\
\hline
\end{tabular}

A massa unitária do cimento varia entre 1,25 e $1,35 \mathrm{~kg} / \mathrm{l}$ e a massa específica entre $3150 \mathrm{~kg} / \mathrm{m}^{3}$ a $3200 \mathrm{~kg} / \mathrm{m}^{3}$.

\subsection{Tipos de cimento Portland}

No Brasil existem vários tipos de cimento Portland diferentes entre si, no que diz respeito à sua composição e à finura de seus grãos; entretanto, aqui serão abordados somente aqueles mais comuns:

- Cimento Portland comum;

- Cimento Portland composto;

- Cimento Portland de alto forno;

- Cimento Portland pozolânico;

- Cimento Portland de alta resistência inicial.

Em menor escala são consumidos os seguintes tipos de cimento:

- Cimento Portland resistente aos sulfatos;

- Cimento Portland de alta resistência inicial resistente aos sulfatos.

Apenas para ilustração, citam-se alguns outros tipos de cimento, que podem ser considerados como não convencionais, tais como: 
- Cimento Portland branco;

- Cimento Portland de baixo calor de hidratação;

- Cimento Portland para poços petrolíferos;

- Cimento Portland de alta resistência inicial resistente a sulfatos com sílica ativa.

Na tabela 1.3, são apresentadas a composição dos cimento Portland comum e compostos:

Tabela 1.3 - Composição do cimento Portland comum e cimento Portland composto (KATTAR \& ALMEIDA, 1999)

\begin{tabular}{cccccc}
\hline $\begin{array}{c}\text { Tipo de } \\
\text { cimento } \\
\text { Portland }\end{array}$ & Sigla & $\begin{array}{c}\text { Clínquer }+ \\
\text { gesso } \\
\mathbf{( \% )}\end{array}$ & $\begin{array}{c}\text { Escória } \\
\text { granulada de } \\
\text { alto forno } \\
\mathbf{( \% )}\end{array}$ & $\begin{array}{c}\text { Material } \\
\text { pozolânico } \\
\mathbf{( \% )}\end{array}$ & $\begin{array}{c}\text { Material } \\
\text { Carbonático } \\
\mathbf{( \% )}\end{array}$ \\
\hline Comum & CP I & 100 & $1-5$ & $1-5$ & $1-5$ \\
& CPI-S & $99-95$ & & & \\
\hline Composto & CP II - E & $94-56$ & $6-34$ & - & $0-10$ \\
& CP II - Z & $94-76$ & - & $6-14$ & $0-10$ \\
& CP II - F & $94-90$ & - & - & $0-10$ \\
\hline
\end{tabular}

$\mathrm{O}$ alto consumo de energia durante o processo de fabricação de cimento e algumas qualidades desejáveis encontradas na sua hidratação motivaram o uso de escórias granuladas de alto forno e materiais pozolânicos na composição dos chamados cimentos Portland de alto forno e pozolânicos, respectivamente. A Tabela 1.4 apresenta suas respectivas composições.

Tabela 1.4 - Composição do cimento Portland de alto forno e pozolânico (KATTAR \& ALMEIDA, 1999)

\begin{tabular}{cccccc}
\hline $\begin{array}{c}\text { Tipo de } \\
\text { cimento } \\
\text { Portland }\end{array}$ & Sigla & $\begin{array}{c}\text { Clínquer } \\
\text { gesso } \\
\mathbf{( \% )}\end{array}$ & $\begin{array}{c}\text { Escória } \\
\text { granulada de } \\
\text { alto forno } \\
\mathbf{( \% )}\end{array}$ & $\begin{array}{c}\text { Material } \\
\text { pozolânico } \\
\mathbf{( \% )}\end{array}$ & $\begin{array}{c}\text { Material } \\
\text { Carbonático }\end{array}$ \\
\hline Alto-Forno & CP III & $65-25$ & $35-70$ & - & $0-5$ \\
\hline Pozolânico & CP IV & $85-45$ & - & $15-50$ & $0-5$ \\
\hline
\end{tabular}

O desenvolvimento da alta resistência inicial do CP V -ARI é conseguido pela utilização de uma dosagem diferente na produção do clínquer, bem como pela 
moagem mais fina do cimento, de modo que, ao reagir com a água, ele adquire elevadas resistências, com maior velocidade. (KATTAR \& ALMEIDA, 1999)

A tabela 1.5 apresenta as composições do CP V ARI.

Tabela 1.5 - Composição do cimento de alta resistência inicial (KATTAR \& ALMEIDA, 1999)

\begin{tabular}{cccccc}
\hline $\begin{array}{c}\text { Tipo de } \\
\text { cimento } \\
\text { Portland }\end{array}$ & Sigla & $\begin{array}{c}\text { Clínquer }+ \\
\text { gesso } \\
\mathbf{( \% )}\end{array}$ & $\begin{array}{c}\text { Escória } \\
\text { granulada } \\
\text { de alto } \\
\text { forno } \\
\mathbf{( \% )}\end{array}$ & $\begin{array}{c}\text { Material } \\
\text { pozolânico } \\
\mathbf{( \% )}\end{array}$ & $\begin{array}{c}\text { Material } \\
\text { Carbonático } \\
(\%)\end{array}$ \\
\hline $\begin{array}{c}\text { Alta } \\
\text { resistência } \\
\text { inicial }\end{array}$ & CP V - ARI & $100-95$ & - & - & $0-5$ \\
\hline
\end{tabular}

Os cimentos Portland resistentes aos sulfatos são aqueles que obedecem a, pelo menos, uma das condições:

- Teor de aluminato tricálcico $\left(\mathrm{C}_{3} \mathrm{~A}\right)$ do clínquer e teor de adições carbonáticas de, no máximo, $8 \%$ e 5\% em massa, respectivamente;

- Cimentos do tipo de alto forno, que contiverem entre 60 e $70 \%$ de escória granulada de alto forno em massa;

- Cimentos do tipo pozolânico, que contiverem entre $25 \%$ e $40 \%$ de material pozolânico em massa.

\subsection{Principais produtos da hidratação do cimento Portland}

Os tipos, quantidades e características das quatro fases sólidas principais, geralmente presentes na pasta de cimento Portland hidratado, são apresentados na Tabela 1.6. 
TABELA 1.6 - Principais características dos produtos de hidratação do cimento Portland (MEHTA \& MONTEIRO, 1994)

\begin{tabular}{|c|c|c|c|}
\hline Produto & Quantidade & Formas & Características \\
\hline $\begin{array}{l}\text { Silicato de } \\
\text { Cálcio } \\
\text { Hidratado } \\
\text { (C-S-H) }\end{array}$ & $\begin{array}{l}50 \% \text { a } 60 \% \\
\text { do volume de } \\
\text { sólidos }\end{array}$ & $\begin{array}{l}\text { partículas de } \\
1 \mathrm{~nm} \text { a } 100 \mathrm{~nm}\end{array}$ & 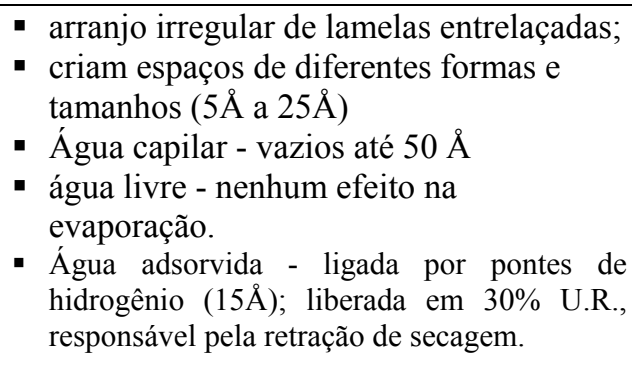 \\
\hline $\begin{array}{c}\text { Portlandita } \\
\mathrm{Ca}(\mathrm{OH})_{2} \text { ou } \mathrm{CH}\end{array}$ & $\begin{array}{l}20 \% \text { a } 25 \% \\
\text { de volume } \\
\text { de sólidos }\end{array}$ & $\begin{array}{l}\text { cristais grandes } \\
\text { prismas } \\
\text { hexagonais } \\
1 \mu \mathrm{m}\end{array}$ & $\begin{array}{l}\text { - Sua contribuição para a resistência se dá } \\
\text { por força de van der Walls }\end{array}$ \\
\hline Sulfoaluminatos & $\begin{array}{l}15 \% \text { a } 20 \% \\
\text { de volume } \\
\text { de sólidos }\end{array}$ & & $\begin{array}{l}\text { - desempenham papel menos importante } \\
\text { na resistência mecânica } \\
\text { - vulneráveis ao ataque por sulfatos. }\end{array}$ \\
\hline
\end{tabular}

Há também a presença de grãos anidros do clínquer, que estão em um intervalo de $1 \mu \mathrm{m}$ a $50 \mu \mathrm{m}$.

\subsection{Minerais adicionados aos cimentos no Brasil}

\subsubsection{Pozolanas}

A pozolana é classificada como um material cimentício, que nada mais é que um material natural ou artificial que contém sílica de forma ativa. Trata-se de um material silicoso ou silícico-aluminoso que, por si só, tem pouco ou nenhum valor cimentício mas, quando finamente subdividido e na presença de umidade, reage quimicamente com o hidróxido de cálcio à temperatura ambiente, formando compostos com propriedades cimentícias. A sílica deve estar no estado amorfo, isto é, vítreo, pois, quando cristalina, sua reatividade é pequena. (NEVILLE, 1997)

Os materiais pozolânicos naturais mais comumente encontrados são: cinzas vulcânicas, pumicita, opalina, micas e calcedônias, terras diatomáceas calcinadas e argila calcinada.

\subsubsection{Escória granulada de alto forno}

É obtida na produção de ferro fundido nas indústrias siderúrgicas e quando resfriada bruscamente, normalmente em água, forma um produto com partículas de 
dimensão de areia que, moído de $400 \mathrm{~m}^{2} / \mathrm{kg}$ a $500 \mathrm{~m}^{2} / \mathrm{kg}$ de finura de Blaine, desenvolvem propriedades cimentantes satisfatórias.

As partículas de escória menores do que $10 \mu \mathrm{m}$ contribuem para as resistências iniciais do concreto até 28 dias; partículas de $10 \mu \mathrm{m}$ a $45 \mu \mathrm{m}$ contribuem para as resistências a longa idade, mas partículas maiores do que $45 \mu \mathrm{m}$ são difíceis de hidratar. (MEHTA \& MONTEIRO, 1994)

Embora tenha propriedades cimentantes, a escória de alto forno finamente moída tem uma reação bastante lenta, necessitando de um ativador para acelerar a hidratação.

A adição de escória de alto forno confere uma série de características ao cimento Portland, tais como o controle da velocidade e a menor liberação de calor na hidratação, fazendo o cimento de alto forno adequado para obras de concreto e argamassa em ambientes marinhos e concretagem de grandes volumes.

Há que se ressaltar que a adição da escória de alto forno ao cimento Portland traz ganhos ao meio ambiente, pois se trata de um material que seria descartado pelas indústrias em aterros, além de propiciar ganhos econômicos, já que esta substitui uma certa quantidade de clínquer que, como já visto, demanda um alta quantidade de energia para sua produção.

A escória de alto forno pode ser utilizada como material cimentício das seguintes maneiras:

- em primeiro lugar, pode ser usada juntamente com o calcário, como matéria-prima para fabricação convencional do cimento Portland por via seca;

- em segundo lugar, pode ser usada como material cimentício, mas na presença de um álcali ativador ou inibidor. $\mathrm{O}$ meio alcalino produzido na hidratação do cimento Portland pode ser álcali ativador das propriedades hidráulicas da escória;

- $\quad$ o terceiro é como adição no cimento Portland de alto forno.

A utilização de cimentos contendo escória granulada de alto forno, tais como o CP II E e o CP III utilizados na pesquisa, é uma das maneiras de diminuir a 
quantidade de $\mathrm{Ca}(\mathrm{OH})_{2}$ na matriz, substituindo parte do clínquer no cimento e diminuindo a formação da Portlandita.

\subsubsection{Cinza volante}

A cinza volante é a cinza obtida por precipitação mecânica ou eletrostática dos gases de exaustão de estações alimentadas por carvão. Trata-se da pozolana artificial mais comum. As partículas de cinza volante são esféricas, o que é uma vantagem sob o ponto de vista de demanda de água, e têm uma finura muito grande: a grande maioria têm um diâmetro entre menos de que $1 \mu \mathrm{m}$ e $100 \mu \mathrm{m}$ e finura de Blaine entre $250 \mathrm{~m}^{2} / \mathrm{kg}$ e $600 \mathrm{~m}^{2} / \mathrm{kg}$, o que significa que o material está prontamente disponível para reação com hidróxido de cálcio. (NEVILLE, 1997)

\subsubsection{Sílica ativa}

Trata-se de um subproduto da fabricação de silício ou de ligas de ferrosilício a partir de quartzo de elevada pureza e carvão em forno elétrico de eletrodos de arco submerso. O SiO que se desprende na forma de gás oxida-se e se condensa, gerando partículas esféricas extremamente pequenas de sílica amorfa $\mathrm{SiO}_{2}$. A sílica, na forma de material vítreo, é muitíssimo reativa e o pequeno tamanho das partículas acelera as reações com o $\mathrm{Ca}(\mathrm{OH})_{2}$, produzido na hidratação do cimento Portland. As pequeníssimas partículas de sílica ativa entram no espaço entre as partículas de cimento, melhorando, assim, a compacidade da pasta.

O grão de sílica ativa é muito pequeno, o Blaine por adsorção de nitrogênio, chega a valores de $20000 \mathrm{~m}^{2} / \mathrm{kg}$, que é 13 a 20 vezes maior do que a área específica de outros materiais pozolânicos e grande parte das partículas têm diâmetro entre $0,03 \mu \mathrm{m}$ e $0,3 \mu \mathrm{m}$. Um material tão fino tem uma massa unitária muito baixa: $200 \mathrm{~kg} / \mathrm{m}^{3}$ a $300 \mathrm{~kg} / \mathrm{m}^{3}$. O manuseio deste material é difícil e caro, por esse motivo, a sílica ativa é encontrada em pelotas, isto é, aglomerados de partículas produzidos por aeração, com massa unitária de $500 \mathrm{~kg} / \mathrm{m}^{3}$ a $700 \mathrm{~kg} / \mathrm{m}^{3}$. (NEVILLE, 1997)

A Tabela 1.7 apresenta um resumo das principais propriedades físicas da sílica ativa, baseado em MORAIS (2001). 
TABELA 1.7 - Resumo das principais propriedades físicas da sílica ativa

\begin{tabular}{ll}
\hline \multicolumn{1}{c}{ Propriedade } & \multicolumn{1}{c}{ Descrição } \\
\hline Tamanho médio & Em média 100 vezes mais fino que o cimento \\
Área específica & De $20.000 \mathrm{~m}^{2} / \mathrm{kg} \mathrm{a} 25.000 \mathrm{~m}^{2} / \mathrm{kg}$ \\
Forma das partículas & Esféricas \\
Massa Específica & Da ordem $2.200 \mathrm{~kg} / \mathrm{m}^{3}$ \\
Massa Unitária & Em torno de $600 \mathrm{~kg} / \mathrm{m}^{3} \mathrm{p} /$ produto compacto \\
Coloração & Cinza \\
\hline
\end{tabular}

Pode-se esperar da sílica ativa duas importantes características: a reação pozolânica, uma das primeiras motivações que levou à sua utilização neste trabalho e o efeito microfiller, que pode ser considerado uma das principais propriedades da sílica ativa, pois, numa substituição de $15 \%$ de cimento por sílica existem cerca de 2.000.000 partículas de sílica para cada grão de cimento. (MORAIS, 2001)

Observação: A cinza volante e a sílica ativa são utilizados com maior freqüência como adição às argamassas e aos concretos no momento da mistura.

\subsection{Estudo da alcalinidade da matriz de cimento Portland}

\subsubsection{A água dos poros da pasta de cimento}

O estudo da água dos poros da pasta de cimento hidratada é de grande relevância para a durabilidade dos compósitos de cimento Portland reforçados com fibras de vidro tipo E, frente ao meio alcalino, pois se trata da água livre apta a reagir com os grãos anidros, com produtos hidratados, com espécies químicas externas que eventualmente penetram no interior da pasta e da fibra de vidro. A variável mais explorada é o $\mathrm{pH}^{4}$. A água dos poros da pasta de cimento apresenta-se como uma solução de íons cuja composição depende do cimento, da quantidade de água de

\footnotetext{
${ }^{4} \mathrm{O}$ pH é a medida de acidez e basicidade de um líquido, obtido a partir da dissociação da água, é dada por: $\mathbf{H}_{2} \mathbf{O}$ $\Leftrightarrow \mathbf{H}^{+}+\mathbf{O H}^{-}$. O produto das concentrações de $\mathrm{H}^{+}$e do $\mathrm{OH}^{-}$é ígual a $10^{-14}$. Para água pura : $\left[\mathbf{H}^{+}\right]=\left[\mathbf{O H} \mathbf{H}^{-}\right]=\mathbf{1 0}^{-7}$ de tal forma que, em soluções ácidas: $\left[\mathbf{H}^{+}\right]>\mathbf{1 0}^{-7}$ e $\left[\mathbf{O H} \mathbf{H}^{-}\right]<\mathbf{1 0}^{-7}$ e em soluções básicas: $\left[\mathbf{H}^{+}\right]<\mathbf{1 0}^{-7}$ e $\left[\mathbf{O H}^{-}\right]$ $>10^{-7}$. Adota-se $\mathbf{p H}=-\log \left[\mathbf{H}^{+}\right]$e pOH $=-\log \left[\mathrm{OH}^{-}\right]$. Desta forma, considerando $\mathbf{p}=-\log$, tem-se $\mathbf{p H}+\mathbf{p O H}$ $=\mathbf{1 4}$, ou seja, em águas puras (soluções neutras): $\mathbf{p H}=\mathbf{p O H}=\mathbf{7}$; em águas ácidas: $\mathbf{p H}<\mathbf{7} \mathbf{e} \mathbf{p O H}>\mathbf{7}$ e, em soluções básicas, $\mathbf{p H}>7 \mathbf{e} \mathbf{p O H}<7$.
} 
amassamento, do grau de hidratação do cimento e da interação com o meio externo. (OLIVEIRA \& AGOPYAN, 2000)

São nas águas dos poros capilares que as partículas de $\mathrm{Ca}(\mathrm{OH})_{2}$ disponíveis estarão dissolvidas, levando a crer que, se a interconexão dos poros for evitada, será possível diminuir o transporte de íons que possam reagir com a fibra de vidro. Neste trabalho, essa interconexão deverá ser evitada através do aumento da compacidade da argamassa, com uma boa distribuição dos finos e do filme de polímero.

\subsubsection{Alcalinidade do concreto e argamassa: seus benefícios e prejuízos}

A alcalinidade da água dos poros da pasta de cimento gira entre 12,6 e 13,5. O aço envolto pela pasta de cimento hidratado forma rapidamente uma camada de passivação delgada de óxido que adere fortemente ao aço e proporciona uma proteção completa contra a reação com oxigênio e com água, isto é, contra a corrosão ou formação de ferrugem. A preservação da passivação é condicionada por um pH adequadamente alto da água dos poros em contato com a camada passivadora. Assim, quando o $\mathrm{pH}$ baixo atinge as proximidades da superfície do aço da armadura, a película protetora é removida e pode ocorrer corrosão, desde que estejam presentes o oxigênio e a umidade necessários para reações de corrosão. (NEVILLE, 1997)

Segundo SAVASTANO (2000), no caso de concreto e argamassa reforçados com fibras, a região da matriz em torno da fibra (zona de transição fibramatriz) é caracterizada por uma porosidade elevada, permitindo acúmulo de água, e pela presença de grandes quantidades de hidróxido de cálcio, propiciando elevada alcalinidade.

Um nível alto de alcalinidade pode ser desejável, como no caso de concreto e argamassa armada com aço, mas pode comprometer o desempenho de concreto e argamassa reforçados com fibras susceptíveis ao ataque do meio alcalino, como a fibra de vidro, causando uma rápida perda de resistência mecânica, através do chamado envelhecimento ou degradação das fibras. 


\subsection{3. $\mathrm{O}$ pH e o $\mathrm{Ca}(\mathrm{OH})_{2}$ presentes nas argamassas de cimento Portland}

SEIDLER (2001), utilizando argamassa e pasta de cimento compostas de CP I - S, relação água/aglomerante 0,70 e adição de sílica ativa de $30 \%$, obteve teores de $\mathrm{Ca}(\mathrm{OH})_{2}$ próximos de zero a partir dos 7 dias de idade, mas também obteve valores de $\mathrm{pH}$ em torno de 12. Porém, aos 126 dias, notou a presença de $\mathrm{K}(\mathrm{OH})_{2}$, indicando haver uma reserva alcalina responsável pela manutenção do $\mathrm{pH}$ elevado, mesmo sob consumo quase total de $\mathrm{Ca}(\mathrm{OH})_{2}$.

Oliveira (2000), afirma que,

"Segundo GLASSER (1991), o pH do poro de cimentos com escória está entre 12 e 13, e não havendo evidências de que esse valor seja reduzido espontaneamente para valores próximos a 10,6, pH no qual existe o risco de despassivação do aço. Ainda segundo o mesmo autor, no caso de lixiviação de álcalis em pastas de cimento Portland com elevado teor de escória, analogamente ao cimento Portland comum, o $\mathrm{CH}$ e o $C-S-H$ dissolvem-se restabelecendo a concentração de ions $\mathrm{OH}^{-}$e $\mathrm{Ca}^{2+}$ na solução."

De acordo com o exposto acima, é possível afirmar que o valor do $\mathrm{pH}$ não é a variável mais adequada para indicar o comportamento esperado da fibra de vidro quando dispersa na matriz de cimento Portland, mas sim, através da quantificação dos íons de $\mathrm{Ca}(\mathrm{OH})_{2}$ presentes nesta matriz.

\subsubsection{O mecanismo da reação pozolânica}

Segundo AFRIDI et al. (1989), a Portlandita ocupa entre 20\% e 25\% em volume do total dos produtos hidratados do cimento Portland.

A formação da Portlandita $\mathrm{Ca}(\mathrm{OH})_{2}$ pode ser proveniente tanto do processo de hidratação da Alita $\left(\mathrm{C}_{3} \mathrm{~S}\right)$ como da Belita $\left(\mathrm{C}_{2} \mathrm{~S}\right)$, porém, a quantidade de Portlandita produzida na hidratação da alita é bem maior que na Belita, daí, se utilizar a hidratação da Alita para o exemplo de formação de $\mathrm{CH}$. 
Com relação à reação principal de formação de $\mathrm{C}-\mathrm{S}-\mathrm{H}$, é útil uma comparação entre o cimento Portland e o cimento pozolânico com a finalidade de compreender-se as reações para as diferenças entre os seus comportamentos:

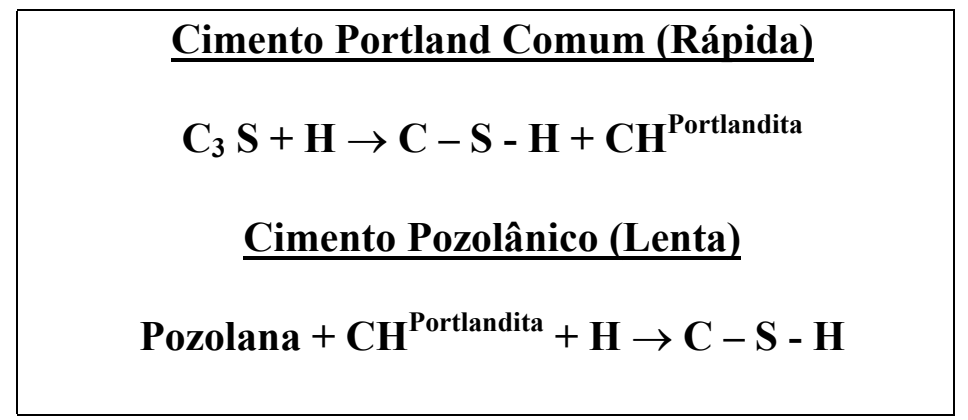

A reação entre a pozolana e o hidróxido de cálcio é chamada reação pozolânica.

Nesse trabalho utilizou-se a sílica ativa para realizar a reação pozolânica, como forma de diminuir a quantidade Portlandita no compósito e o CP III (cimento de alto forno) por ter menor quantidade de clínquer. 
CAPÍTULO

\section{Argamassa Reforçada com Fibras}

\subsection{Preâmbulos}

O reforço de argamassas e concretos de cimento Portland com fibras é uma maneira bastante eficiente de reduzir a fragilidade na ruptura destes materiais, aumentar a durabilidade e conferir propriedades mecânicas não encontradas nas argamassas e concretos convencionais, relacionadas à capacidade de deformação e absorção de energia.

\subsection{Alguns parâmetros relevantes no reforço de argamassas com fibras}

\section{a. Relação de aspecto}

É um parâmetro numérico bastante conveniente para descrever uma fibra. Trata-se da relação entre o seu comprimento e o diâmetro equivalente da mesma.

Segundo GUIMARÃES (1999), a relação de aspecto é um parâmetro importante para o desempenho das fibras lisas pois, quando a relação de aspecto aumenta, a ductilidade do compósito aumenta, desde que as fibras possam ser adequadamente misturadas com a argamassa ou o concreto.

\section{b. Densidade linear}

Usualmente, a densidade linear das fibras é descrita em termos de peso por unidade de comprimento - ou TEX.

\section{c. Comprimento crítico}

É o comprimento mínimo requerido para que a tensão resistida pela fibra seja igual à sua resistência.

Segundo GUIMARÃES (1999), o tamanho da fibra, relativamente ao seu comprimento crítico, tem influência não só na sua eficiência, mas também no modo de fratura. Um comprimento menor que o crítico é associado à ruptura do compósito por 
arrancamento das fibras. Se o comprimento for maior, a ruptura da fibra acontecerá antes do seu arrancamento, com relação à matriz.

\section{d. Módulo de elasticidade}

Segundo TEZUKA (1989), as fibras de polipropileno ou de polietileno, que têm módulo de elasticidade menor e alongamento maior do que as da matriz de cimento, dão compósitos com pequeno aumento de resistência mas capazes de absorver grandes energias e, portanto, grande resistência ao impacto e tenacidade.

As fibras de módulo de elasticidade elevado e grande resistência, tais como as fibras de vidro, aço, e carbono, produzem compósitos com alta resistência à tração e absorção de cargas dinâmicas.

\section{e. Outros parâmetros importantes}

A Tabela 2.1 apresenta valores de algumas propriedades da matriz de cimento Portland comum.

TABELA 2.1 - Algumas propriedades da matriz de cimento Portland comum TEZUKA (1989)

\begin{tabular}{|c|c|c|c|c|}
\hline Matriz & $\begin{array}{c}\text { Massa } \\
\text { Específica } \\
\left(\mathbf{k g} / \mathbf{m}^{3}\right)\end{array}$ & $\begin{array}{c}\text { Módulo } \\
\text { Young } \\
\left(\mathbf{k N} / \mathbf{m m}^{2}\right)\end{array}$ & $\begin{array}{c}\text { Resistência à } \\
\text { tração } \\
\left(\mathbf{N} / \mathbf{m m}^{2}\right)\end{array}$ & $\begin{array}{c}\text { Alongamento } \\
\text { ruptura (\%) }\end{array}$ \\
\hline Pasta & 2000 a 2200 & 10 a 30 & 3 a 8 & 0,01 a 0,05 \\
\hline Argamassa & 2200 a 2300 & 25 a 35 & 2 a 4 & 0,005 a 0,015 \\
\hline Concreto & 2300 a 2450 & 30 a 40 & 1 a 4 & 0,005 a 0,015 \\
\hline
\end{tabular}

A Tabela 2.2 apresenta algumas características e propriedades mecânicas e químicas das fibras. 
TABELA 2.2 - Algumas características e propriedades mecânicas e químicas das fibras TEZUKA (1989)

\begin{tabular}{|c|c|c|c|c|c|c|c|}
\hline Tipo & $\begin{array}{c}\text { Diâmetro } \\
(\mu \mathbf{m})\end{array}$ & $\begin{array}{c}\text { Massa } \\
\text { Espec. } \\
\left(\mathrm{Kg} / \mathbf{m}^{3}\right)\end{array}$ & $\begin{array}{l}\text { Coef. } \\
\text { Poisson }\end{array}$ & $\begin{array}{c}\text { Resist. } \\
\text { Tração } \\
\left(\mathbf{N} / \mathbf{m m}^{2}\right)\end{array}$ & $\begin{array}{c}\text { Módulo } \\
\text { Young } \\
\left(\mathbf{k N} / \mathbf{m m}^{2}\right) \\
\end{array}$ & $\begin{array}{c}\text { Alongam } \\
\text { Ruptura } \\
(\%) \\
\end{array}$ & $\begin{array}{l}\text { Resist. } \\
\text { aos } \\
\text { álcalis }\end{array}$ \\
\hline Amianto & 0,02 a 20 & 2550 & 0,3 & 3500 & 168 & 2 a 3 & Boa \\
\hline Aço & 5 a 500 & 7840 & 0,28 a 0,33 & 1000 a 3000 & 196 a 210 & 3 a 4 & Boa \\
\hline Vidro E & 9 a 15 & 2550 & 0,22 a 0,25 & 2100 a 3500 & 77 & 2 a 3,5 & Pobre \\
\hline Vidro AR & 10 a 20 & 2700 & 0,22 & 2000 a 2800 & 70 a 84 & 2 a 3 & Razoav \\
\hline Carbono & 8 & 1900 & 0,2 a 0,4 & 2450 a 3150 & 230 a 315 & 1 & Boa \\
\hline $\begin{array}{l}\text { Poliprop. } \\
\text { Fibrilado }\end{array}$ & 4 a 30 & 910 & 0,29 a 0,46 & 300 a 400 & 6 a 8 & 8 & Boa \\
\hline Coco & 100 a 400 & - & - & 120 a 200 & 19 a 26 & 10 a 25 & Pobre \\
\hline Sisal & 7 a 47 & - & - & 280 a 568 & 13 a 26 & 3 a 5 & Pobre \\
\hline Juta & 20 a 100 & - & - & 250 a 350 & 26 a 32 & 1,5 a 2 & Pobre \\
\hline
\end{tabular}

É importante ressaltar que a adição de qualquer tipo de fibra à argamassa ou ao concreto convencional reduz a sua trabalhabilidade e essa perda é proporcional à concentração volumétrica de fibras.

Essa limitação da trabalhabilidade deverá ser contornada por meio de uma correta seqüência de preparo da argamassa ou do concreto e da adição de aditivos incorporadores de ar, plastificantes e um maior teor de pasta.

A utilização de fibras nas argamassas ou nos concretos pode exigir a utilização de betoneiras especiais em lugar das convencionais, para evitar empelotamentos indesejáveis na massa. Também o adensamento deverá ser feito com vibradores especiais, como a mesa vibratória ou correspondente.

\subsection{Aplicações das argamassas e concretos reforçados com fibras}

Segundo TEZUKA (1989), a escolha do tipo de fibra deve ser feita tomando-se como princípio as características que se deseja obter para o compósito.

MEHTA \& MONTEIRO (1994) afirmam que o compósito de cimento reforçado com fibras tem grande variedade de aplicações, incluindo pavimentos para rodovias, estruturas de pontes, túneis, obras hidráulicas, estruturas resistentes a explosões, etc.. 
Outra importante linha de aplicação das argamassas e concretos reforçados com fibras é a dos elementos esbeltos, tais como as placas de fibrocimento para o sistema dry wall, revestimento de fachada, divisórias, coberturas, etc..

\subsection{Propriedades mecânicas do concreto reforçado com fibras}

\subsubsection{Resistência à compressão}

Segundo GUIMARÃES (1999), maiores resistências à compressão sempre resultam em rupturas mais frágeis, tanto para argamassas e concretos convencionais quanto para aqueles reforçados com pequenas quantidades de fibras. Maiores quantidades de fibras deverão ser adicionadas conforme se aumenta a resistência à compressão das argamassas ou dos concretos para que esses possam produzir ruptura dúctil.

A resistência à compressão deve ser o parâmetro inicial a ser considerado no estudo dos concretos e argamassas reforçados com fibras. A partir daí, procura-se melhorar os outros aspectos mecânicos desejáveis do compósito, tais como a resistência à tração, à flexão, ao impacto e tenacidade, pela adição de fibras.

\subsubsection{Interação fibra-matriz}

Segundo BALAGURU \& SHAH (1992) os principais parâmetros que afetam a interação fibra-matriz são:

- condição da matriz (fissurada ou não fisurada);

- composição da matriz;

- geometria da fibra;

- $\quad$ tipo de fibra (metálica, polimérica, vidro,etc);

- características da superfície da fibra;

- $\quad$ rigidez da fibra em comparação a da matriz

- orientação das fibras (alinhadas ou distribuídas aleatoriamente);

- quantidade de fibras adicionadas;

- velocidade de carregamento; 
- durabilidade das fibras no compósito.

O mecanismo de transferência de tensões elásticas da matriz para as fibras pode ser mais facilmente notado quando o processo de fissuração está acontecendo, mas esta transferência também ocorre antes mesmo que aconteça qualquer fissuração da matriz. A tensão desenvolvida na interface fibra-matriz é a de cisalhamento, que faz a distribuição da ação externa entre a fibra e a matriz desde que elas tenham módulos de elasticidade diferentes, mas as deformações destes dois componentes permanecem as mesmas.

Segundo GUIMARÃES (1999), nas matrizes que ainda não sofreram fissuração, quando a ação é aplicada no elemento, parte da ação é transferida para as fibras ao longo de sua superfície. Por causa da diferença de rigidez entre a fibra e a matriz, tensões de cisalhamento desenvolvem-se ao longo da superfície da fibra (Figura 2.1.a). Se a fibra é mais rígida que a matriz - é o caso da fibra de vidro - a deformação ao longo da fibra será menor, como é mostrado na Figura 2.1.b e 2.1.c. Se o módulo de elasticidade da fibra é menor que o módulo de elasticidade da matriz, então a deformação ao redor da fibra será maior (fibras poliméricas e algumas fibras naturais).

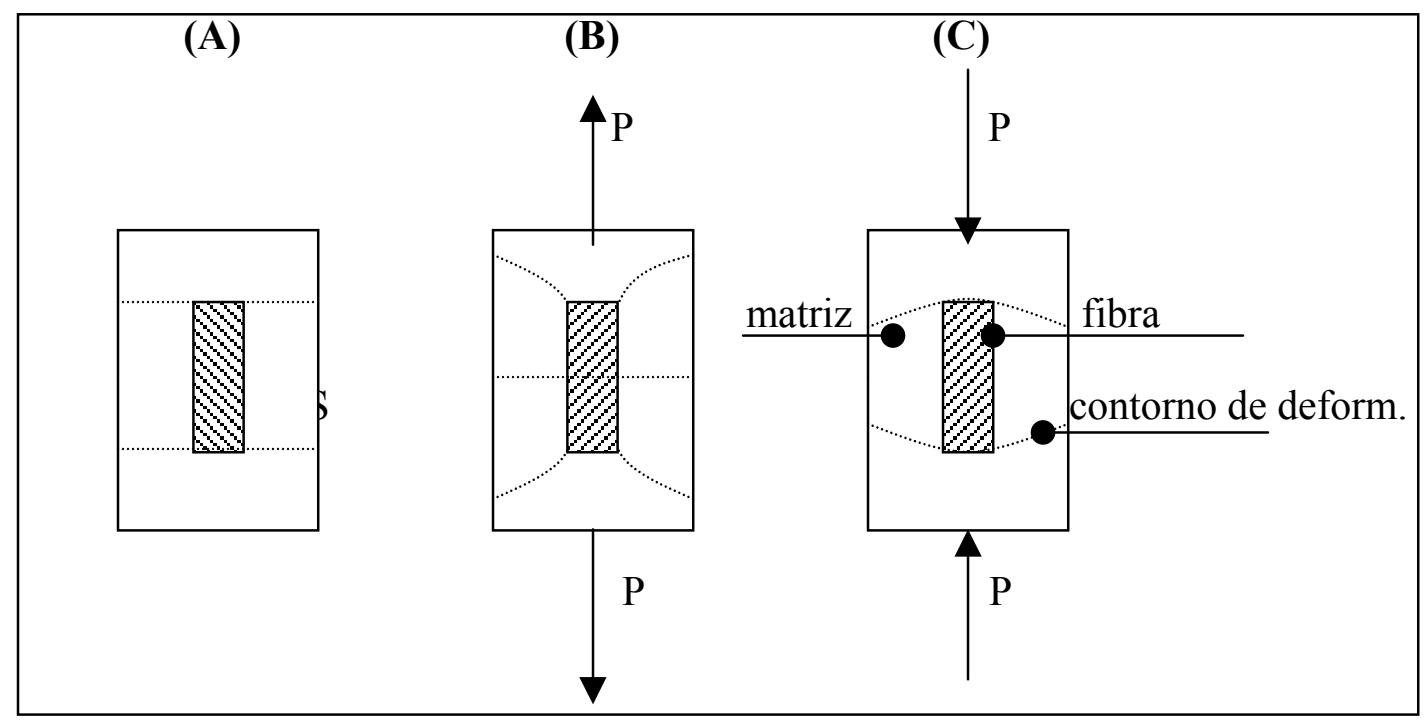

FIGURA 2.1 - Interação fibra-matriz com a matriz não fissurada: a) descarregada; b) submetida à tração e c) submetida à compressão (BALAGURU \& SHAH, 1992) 


\subsubsection{Fenômeno de grampeamento de fissuras}

EKANE (2000) afirma que a introdução de uma fissura em concreto ou argamassa pode se iniciar antes mesmo da aplicação de um carregamento, a partir de microfissuras existentes em defeitos, tais como vazios e pequenas fissuras que normalmente se fazem presentes em concretos e argamassas convencionais ou em partículas de agregado miúdo e graúdo, ocasionando a perda de aderência destes da pasta de cimento que os envolve.

Sob um carregamento externo, as microfissuras se coalescem umas com as outras para formar fissuras maiores, que podem até se encontrar com uma macrofissura externa, se não houver nenhum obstáculo que impeça esse acontecimento. Nos concretos e argamassas convencionais, os vazios são obstáculos muito importantes, pois são livres de tensão e, portanto, atraem microfissuras que procuram um caminho de menor resistência. (EKANE,2000)

Já no caso de concretos e argamassas reforçados com fibras, as fibras atuam como um obstáculo para essa coalescência de microfissuras, concentrando-as em torno de si e atuando no que se pode chamar de grampeamento das macrofissuras ilustrado na Figura 2.2.

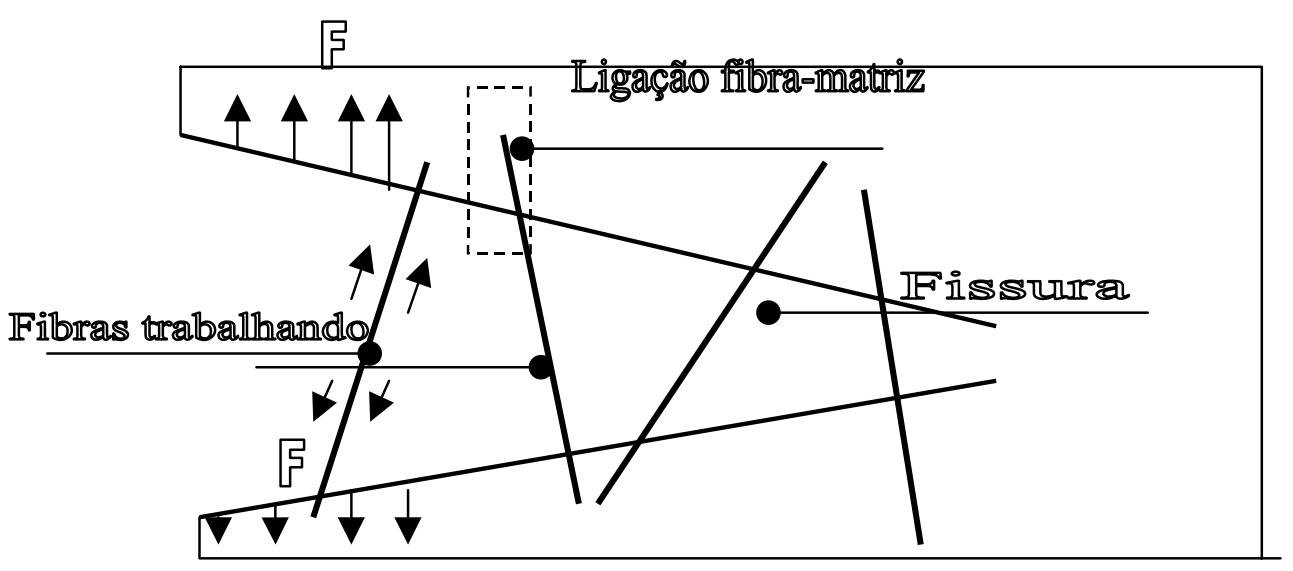

\section{FIGURA 2.2 - Representação esquemática do processo de grampeamento de fissuras pelas fibras}

\subsubsection{Resistência à tração e flexão}

Pelo mecanismo de interação fibra-matriz e do grampeamento de fissuras é possível entender, em linhas gerais, como é feita a transferência das tensões de tração e flexão da matriz para as fibras. 
No estudo do presente trabalho, como visto, a fibra de vidro tem um módulo de elasticidade aproximadamente duas vezes maior que da argamassa (77 $\mathrm{kN} / \mathrm{mm}^{2}$ e $\sim 35 \mathrm{kN} / \mathrm{mm}^{2}$, respectivamente), portanto, após fissurada a matriz, a fibra de vidro atuará efetivamente no travamento das fissuras, quando submetidas à tração e à flexão. Essa transferência das tensões da matriz para as fibras é a responsável pela maior resistência à tração, à flexão, ao impacto e tenacidade esperados do compósito.

\subsection{A utilização das fibras de vidro em argamassa e concreto}

\subsubsection{A fibra de vidro comum}

Embora as fibras de vidro sejam confeccionadas com um material frágil o vidro - elas possuem propriedades satisfatórias para o emprego na construção civil, tais como: baixo coeficiente de dilatação térmica, resistência à tração e à vibração, retenção das propriedades mecânicas a altas temperaturas, grande alongamento na ruptura, facilidade de processamento, baixo custo se comparadas às outras fibras dúcteis, além de não serem passíveis de inalação, o que representa uma grande vantagem se comparado ao amianto. A justificativa para a maior resistência das fibras de vidro em relação ao vidro está na menor quantidade de defeitos microscópicos que a primeira tem frente ao segundo, defeitos esses que são responsáveis pelo enfraquecimento dos materiais. (OLIVEIRA, 2000)

A fibra de vidro tipo E (elétrico), aqui algumas vezes chamada de convencional, tem inadequada resistência ao meio alcalino da matriz de cimento Portland, causando uma deterioração das propriedades mecânicas e fazendo com que a fibra de vidro convencional perca sua flexibilidade e sua resistência à tração, o que fragiliza todo o compósito.

Segundo PURNELL (2001), o mecanismo de degradação da fibra de vidro é complexo, mas, pode-se dizer que a matriz de cimento continua seu processo de cura durante alguns anos, com isso, cristais de $\mathrm{Ca}(\mathrm{OH})_{2}$ se formam sobre e ao redor dos fios da fibra de vidro, causando uma perda de flexibilidade da fibra e, conseqüentemente, do compósito.

Na Introdução dessa dissertação, foi dito que PURNELL et al (2000) atribuem a baixa durabilidade das fibras de vidro convencionais em argamassas de 
cimento Portland à corrosão das fibras pelo $\mathrm{Ca}(\mathrm{OH})_{2}$, à precipitação dos produtos da hidratação (especialmente do $\mathrm{Ca}(\mathrm{OH})_{2}$ ) e à densificação da matriz na interface, reduzindo a flexibilidade das fibras.

Para contornar a degradação das fibras de vidro, PURNELL et al (2000) apresentam dois caminhos: $1^{\circ}$ ) melhoria da resistência das fibras, por meio do uso de fibra de vidro AR ou do preparo da sua superfície; $2^{\circ}$ ) modificação das matrizes de cimento.

A seguir serão analisados os dois diferentes tipos de procedimentos propostos por PURNELL et al (2000) para contornar a degradação da fibra de vidro pelo meio alcalino do cimento Portland.

\subsubsection{Fibra de vidro álcali resistente}

A resistência da fibra de vidro AR foi conseguida por meio da presença de cerca de $16 \%$ de óxido de zircônio $\left(\mathrm{ZrO}_{2}\right)$ na composição do vidro (TEZUKA, 1989; PARDELA e AGUILA, 1998), obtendo uma fibra de vidro que representava uma considerável resistência ao ataque dos álcalis, a qual recebeu o nome comercial de CEM-FIL 1.

Segundo MARTEN (1998), a composição do vidro resistente aos álcalis pode variar, mas todos eles contêm óxido de zircônio e a quantidade ótima da presença deste gira entre $15 \%$ e $20 \%$. Quantidades abaixo de 15\% mostraram progressiva perda da resistência química e pequeno ou nenhum benefício adicional, acima de $20 \%$.

As fibras de vidro álcali resistente (AR) são usadas para auxiliar a diminuição do ataque do $\mathrm{pH}$ elevado mas não resolvem totalmente o problema da durabilidade, devido ao $\mathrm{Ca}(\mathrm{OH})_{2}$.

Segundo PARDELA e DEL AGUILA (1992), a deterioração com o tempo do GRC utilizando fibra AR não pode ser explicada apenas pelo ataque do meio alcalino do cimento Portland às fibras. Os autores citam que dois mecanismos de degradação coexistem:

- o ataque químico das fibras de vidro;

- o crescimento de produtos da hidratação do cimento entre os filamentos das fibras. 
O primeiro mecanismo, principal responsável pela degradação das fibras tipo E, segue subsistindo com menor importância nas fibras de vidro AR, tornando o segundo mecanismo mais relevante. O desenvolvimento e crescimento de produtos da hidratação do cimento, principalmente o $\mathrm{Ca}(\mathrm{OH})_{2}$, envolvem os filamentos de vidro, aumentando a aderência fibra-matriz e fragilizando o material. (PARDELA e DEL AGUILA,1992)

PURNELL et al (2000) chegaram a conclusões idênticas às de PARDELA e DEL AGUILA (1992) e ainda afirmam que o processo de corrosão da fibra de vidro AR pelo ataque químico do meio alcalino do cimento é mínima, ou desprezível, creditando a causa da perda de tenacidade da fibra à densificação da matriz na interface fibra-matriz ${ }^{5}$.

Na Figura $2.3^{6}$, é apresentada uma fotografia da microestrutura da fibra de vidro AR, após processo de hidratação convencional, para matriz de cimento Portland comum, sem adições. Pode-se notar que não existem pontos de corrosão da fibra.

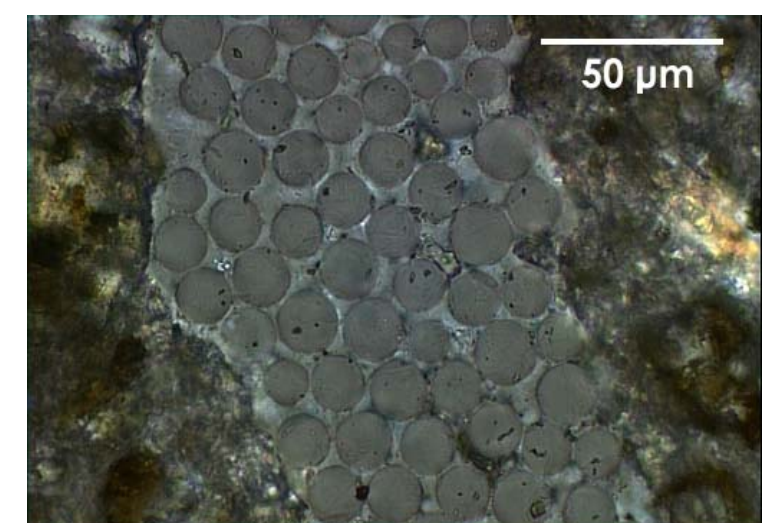

FIGURA 2.3 - Fibra de vidro AR em matriz de cimento Portland comum sem adições após 56 dias de processo de hidratação convencional (PURNELL, 2001)

A Figura $2.4^{7}$ apresenta a fotografia da microestrutura da fibra de vidro $\mathrm{AR}$, após processo de hidratação acelerado $\left(56\right.$ dias a $\left.65^{\circ} \mathrm{C}\right)$, para matriz de cimento Portland comum, sem adições, na qual podem-se notar alguns pontos de corrosão da fibra.

\footnotetext{
${ }^{5}$ As conclusões de PURNELL et al (2000) e PARDELLA e DEL AGULILA (1992) são questionáveis, necessitando, na opinião do autor desta dissertação, de maiores estudos em relação à perda da resistência mecânica da fibra de vidro AR.

${ }^{6}$ Fonte: http:/www.eng.warwick.ac.uk/staff/pp/research.htm\#images

${ }^{7}$ Idem (6)
} 


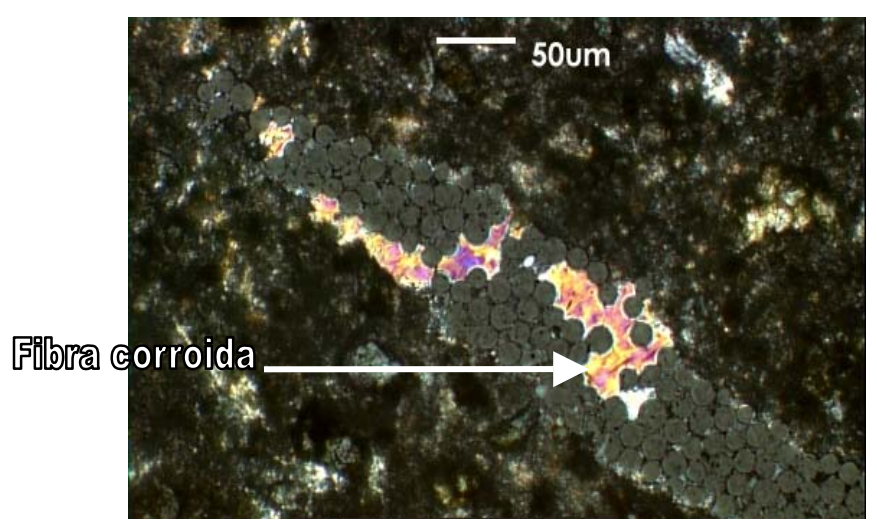

FIGURA 2.4 - Fibra de vidro AR em matriz de cimento Portland comum sem adições após processo de hidratação acelerado de 56 dias a $6^{\circ} \mathrm{C}$ (PURNELL, 2001)

\subsubsection{O tratamento da superfície das fibras}

O preparo da superfície da fibra para resistir ao ataque é outra maneira de melhorar as condições da fibra de vidro. Esse procedimento foi realizado por BARTOS \& ZHU (1996), utilizando o látex acrílico e a sílica ativa na modificação e adição da matriz de cimento, bem como no preparo da superfície das fibras de vidro AR. Os resultados mostraram-se melhores no preparo da superfície, se comparados à modificação da matriz de cimento.

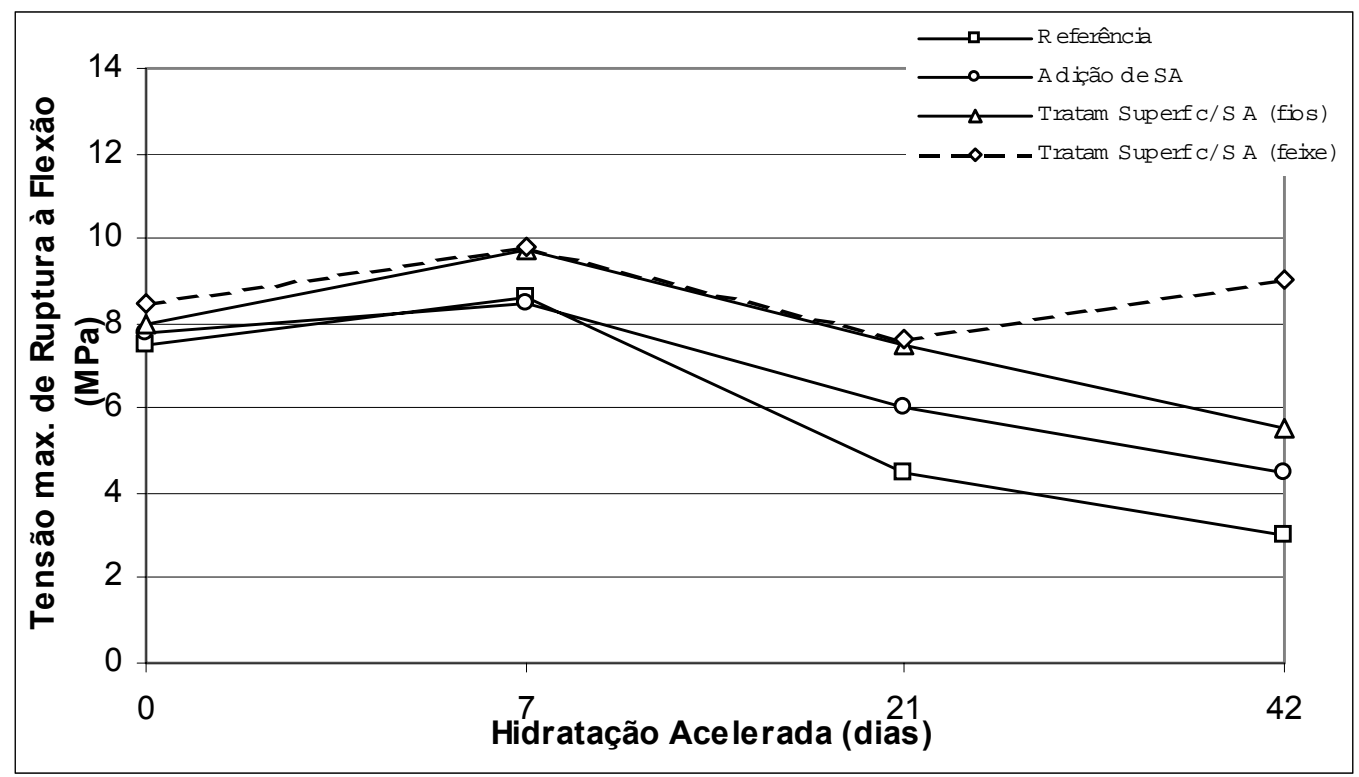

FIGURA 2.5 - Efeito da adição de sílica ativa na argamassa e tratamento da superfície da fibra com sílica ativa (BARTOS \& ZHU,1996) 


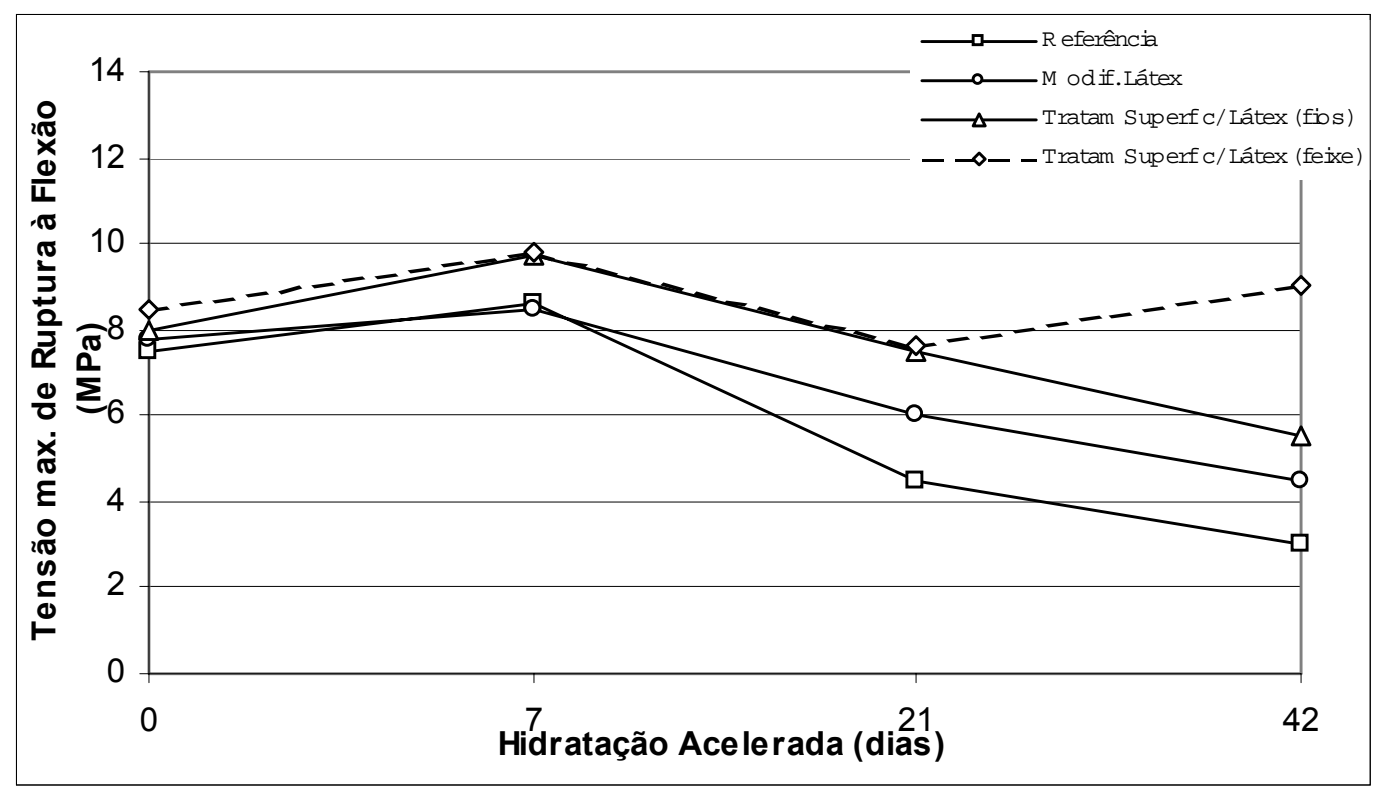

FIGURA 2.6 - Efeito da modificação da argamassa com látex acrílico e tratamento superficial da fibra com látex acrílico

Baseado nos resultados obtidos por BARTOS \& ZHU (1996), apresentados nas Figuras 2.5 e 2.6, o presente trabalho optou por moldar corpos-deprova em forma de placas esbeltas, para ensaio à flexão, com o objetivo de estudar a eficiência do tratamento da superfície de fibras longas (roving) da fibra de vidro tipo E, utilizando o látex SB em vez do látex acrílico.

Para o tratamento da superfície da fibra com sílica ativa, diferente do procedido por BARTOS \& ZHU (1996), que utilizaram uma pasta de sílica e água, utilizou-se uma mistura de sílica ativa com látex SB pois, por hipótese, caso a película de látex SB seja rompida, os íons de hidróxido de cálcio encontrariam partículas de sílica ativa para reação.

\subsubsection{Matriz de cimento com adições}

Uma maneira de contornar o ataque do meio alcalino às fibras de vidro seria a utilização de cimentos que produzem pouco hidróxido de cálcio. 
$\mathrm{Na}$ literatura disponível sobre GRC, encontram-se diversas citações sobre o uso de cimento aluminoso ${ }^{8}$ em substituição ao cimento Portland comum. Na sua hidratação, o cimento aluminoso forma $\mathrm{CAH}_{10}$, uma pequena quantidade de $\mathrm{C}_{2} \mathrm{AH}_{8} \mathrm{e}$ gel de alumina $\mathrm{Al}_{2} \mathrm{O}_{3}$ aquoso. Portanto, não há a presença de hidróxido de cálcio no produto final da reação, embora o $\mathrm{pH}$ da solução dos poros da pasta de cimento aluminoso seja de 11,4 a $12,5^{(9)}$. (NEVILLE, 1997)

Como já foi exposto, nos experimentos deste trabalho, foram utilizados três diferentes tipos de cimento: CP II E, CP V ARI e CP III. O CP III é aquele que produz uma menor quantidade de Portlandita na sua hidratação, já que tem em sua composição aproximadamente $50 \%$ de clínquer, que produz $\mathrm{Ca}(\mathrm{OH})_{2}$. O CP V ARI é aquele que produz uma maior quantidade de $\mathrm{Ca}(\mathrm{OH})_{2}$, pois é composto quase que totalmente por clínquer moído. O estudo do cimento aluminoso não faz parte do escopo do presente trabalho.

Para que um melhor desempenho das fibras de vidro em compósitos de cimento Portland seja possível, novas matrizes de cimento têm sido desenvolvidas, principalmente, através de adições ao cimento, tais como escória de alto forno moída, sílica ativa, cinza volante, metacaulinita ou sulfoaluminato de cálcio. Segundo PURNELL et al (2000), essas adições têm por objetivo baixar o pH da solução dos poros e/ou reduzir ou eliminar a formação de $\mathrm{Ca}(\mathrm{OH})_{2}$ durante a hidratação do cimento Portland.

A sílica ativa foi adicionada na matriz de cimento com o objetivo de consumir o $\mathrm{Ca}(\mathrm{OH})_{2}$ produzido na hidratação do cimento, pois, a maior parte do $\mathrm{Ca}(\mathrm{OH})_{2}$ liberado inicialmente pela hidratação do cimento é rapidamente consumida pela reação pozolânica com sílica ativa. Algumas partículas de sílica ativa podem até permanecer na matriz, mas como cristais muito finos. (DE MELLO, 2000)

Tem sido demonstrado que o $\mathrm{Ca}(\mathrm{OH})_{2}$ é necessário na solução para a dissolução das partículas de sílica ativa, as quais agem como pontos de nucleação. A

\footnotetext{
${ }^{8}$ Trata-se de um cimento composto por cerca de $40 \%$ de alumina e cal, $15 \%$ de óxidos férrico e ferroso e $5 \%$ de sílica. As matérias-primas são geralmente o calcário e a bauxita. O clínquer do cimento aluminoso é obtido a cerca de $1600{ }^{\circ} \mathrm{C}$. (NEVILLE, 1997)

${ }^{9}$ Com o tempo, os cristais de $\mathrm{CAH}_{10}$ que são instáveis, se transformam em cristais de $\mathrm{C}_{3} \mathrm{AH}_{6}$ e gel de alumina. A pequena quantidade de $\mathrm{C}_{2} \mathrm{~S}$ que pode compor o cimento aluminoso forma C-S-H, reagindo o $\mathrm{Ca}(\mathrm{OH})_{2}$ liberado, pela hidrólise, com o excesso de alumina. (NEVILLE, 1997)
} 
subseqüente transformação de partículas de sílica ativa dissolvidas em gel rico em sílica, seguida pela formação do C-S-H, não permite o crescimento livre de grandes cristais de $\mathrm{Ca}(\mathrm{OH})_{2}$ em qualquer estágio de hidratação.

\subsubsection{A modificação da matriz de cimento com látex}

BIJEN (1993) observou uma melhora no desempenho do cimento reforçado com fibras de pela adição látex, utilizando tanto a fibra de vidro tipo $\mathrm{E}$ quanto tipo $\mathrm{AR}$ em argamassas modificadas com látex. Após processo de cura adequada, o pesquisador submeteu-as a processo de hidratação convencional acelerada, correspondendo a dez anos de exposição, segundo procedimentos descritos por LITHERLAND et Al. (1981), obtendo resultados satisfatórios.

$\mathrm{O}$ autor apresenta as seguintes hipóteses para explicar a melhora na durabilidade do GRC modificado com polímero:

i) Redução da água livre sob condições práticas. Esta é, provavelmente, a causa para o declínio no equilíbrio, quando exposto no estado úmido, indicando uma mudança na microestrutura, assim como uma diminuição da taxa de absorção de água. O coeficiente de absorção para o GRC-AR é em torno de $13 \times 10^{-3} \mathrm{~kg} / \mathrm{m}^{2} \cdot \mathrm{S}^{0.5} \mathrm{e}$, para GRC-AR modificado com polímero, em torno de $1 \times 10^{-3} \mathrm{~kg} / \mathrm{m}^{2} \cdot \mathrm{S}^{0.5}$. A adição de polímero confere um GRC hidrófobo. Quando a água livre cai, o ataque alcalino também cai e a cal transportada será limitada;

ii) Proteção da fibra contra o crescimento da cal. Obtida por meio do preenchimento do espaço em torno da fibra pelo polímero, diminuindo o espaço para a cal livre se depositar;

iii) Redução do ataque alcalino, pois o polímero forma um filme que protege a fibra, pelo menos parcialmente.

Segundo AFRIDI et al. (1989), por meio da análise de difração de raio X, nas argamassas de cimento Portland modificadas com polímero, observa-se que conforme se aumenta a relação polímero/ cimento, a quantidade de $\mathrm{Ca}(\mathrm{OH})_{2}$ cai gradualmente. 
“Os resultados apresentados estão coerentes com aqueles apresentados por BHATTY et al., que mostrou que a incorporação de cinza volante e polímero não iônico em cimentos Portland ordinários reduzem a quantidade de $\mathrm{Ca}(\mathrm{OH})_{2}$ formado." (AFRIDI et al.,1989)

A modificação por meio de polímero reduz a presença de $\mathrm{Ca}(\mathrm{OH})_{2}$ possivelmente devido à adsorção deste entre os filmes de polímero, de tal forma que as camadas de filme de polímero blindam o $\mathrm{Ca}(\mathrm{OH})_{2}$. (AFRIDI et al., 1989)

Observando as Figura 2.5 e 2.6, apresentadas por BARTOS \& ZHU (1996), é possível verificar que a modificação do compósito com látex apresentou melhoria de desempenho pouco significativa, comparativamente ao compósito de referência. Melhores resultados se observam na adição de sílica ativa e no tratamento superficial das fibras.

Com os resultados obtidos por BIJEN (1983), AFRIDI et al (1989) e BARTOS \& ZHU (1996), o presente trabalho ganha especial importância pois, nele, além de compósitos com a adição de sílica ativa e compósitos modificados com polímero, estudados por estes autores, estudou-se a modificação com látex e a adição da sílica ativa, concomitantemente em um único compósito.

\subsubsection{Carbonatação da argamassa ou concreto}

Pode-se dizer que carbonatação é a reação dos componentes da pasta de cimento com $\mathrm{CO}_{2}$, presente na atmosfera. Dentre todos os componentes da pasta de cimento, aquele que reage mais rapidamente é o $\mathrm{Ca}(\mathrm{OH})_{2}$, resultando no $\mathrm{CaCO}_{3}$.

A carbonatação pode representar um problema, em relação à durabilidade para o concreto ou argamassa armados com aço, pois reduz o $\mathrm{pH}$ da água dos poros da pasta de cimento de 12,6 a 13,5 para cerca de 9 , possibilitando a despassivação ${ }^{10}$ do aço. NEVILLE (1997), afirma que, quando todo $\mathrm{Ca}(\mathrm{OH})_{2}$ é consumido, o $\mathrm{pH}$ pode ser reduzido a 8,3 .

\footnotetext{
${ }^{10}$ Chama-se camada de passivação do aço uma camada delgada de óxido que adere fortemente a este aço e proporciona uma proteção completa contra reação com o oxigênio e com a água, isto é, contra a corrosão ou a formação de ferrugem. A preservação da passivação é condicionada por um pH alto (segundo alguns autores, $>9,5$ ). NEVILLE (1997)
} 
No caso das argamassas reforçadas com fibra de vidro, quando não forem armadas com estrutura de aço, a carbonatação pode ser utilizada para consumir o $\mathrm{Ca}(\mathrm{OH})_{2}$, embora esse processo seja lento.

A profundidade de carbonatação aumenta proporcionalmente à raiz quadrada do tempo e ainda varia de acordo com a qualidade do concreto ou argamassa (a profundidade e a velocidade aumentam conforme se aumenta a relação água/ aglomerante), o tipo de cura (aumenta com menor tempo de cura úmida), umidade relativa do ar (velocidades maiores entre U.R. entre $50 \%$ e $70 \%$ ) e composição do cimento utilizado (a presença de cinza volante, escória de alto forno e pozolanas podem ser fatores que aumentam a velocidade de carbonatação se a cura não for feita adequadamente). (NEVILLE, 1997)

Como o processo de carbonatação em ambiente natural pode levar décadas e a utilização de $\mathrm{CO}_{2}$ concentrado em câmara fechada, à pressão atmosférica, poderia levar meses, PURNELL (2000), propôs a utilização de dióxido de carbono pressurizado, em torno de 75 atmosferas, a uma temperatura em torno de $40^{\circ} \mathrm{C}$ em elementos de compostos de matrizes de cimento Portland, após processo de cura. A esse processo deu o nome de Carbonatação Super Crítica ${ }^{11}$ e, em ensaios preliminares, obteve um significativo aumento da durabilidade do GRC em relação ao $\mathrm{Ca}(\mathrm{OH})_{2}$, em algumas horas de exposição ao $\mathrm{CO}_{2}$.

O controle do ataque alcalino à fibra de vidro através da carbonatação não faz parte do escopo do presente trabalho, embora seja um novo processo de controle do $\mathrm{Ca}(\mathrm{OH})_{2}$ e esteja em fase de estudos.

\subsubsection{Resumo das possíveis soluções para controle do ataque alcalino às fibras de vidro}

A Figura 2.7, apresentada a seguir, traz um fluxograma das possíveis soluções para controle do ataque alcalino do cimento Portland às fibras de vidro.

${ }^{11}$ Super-critical carbonation 


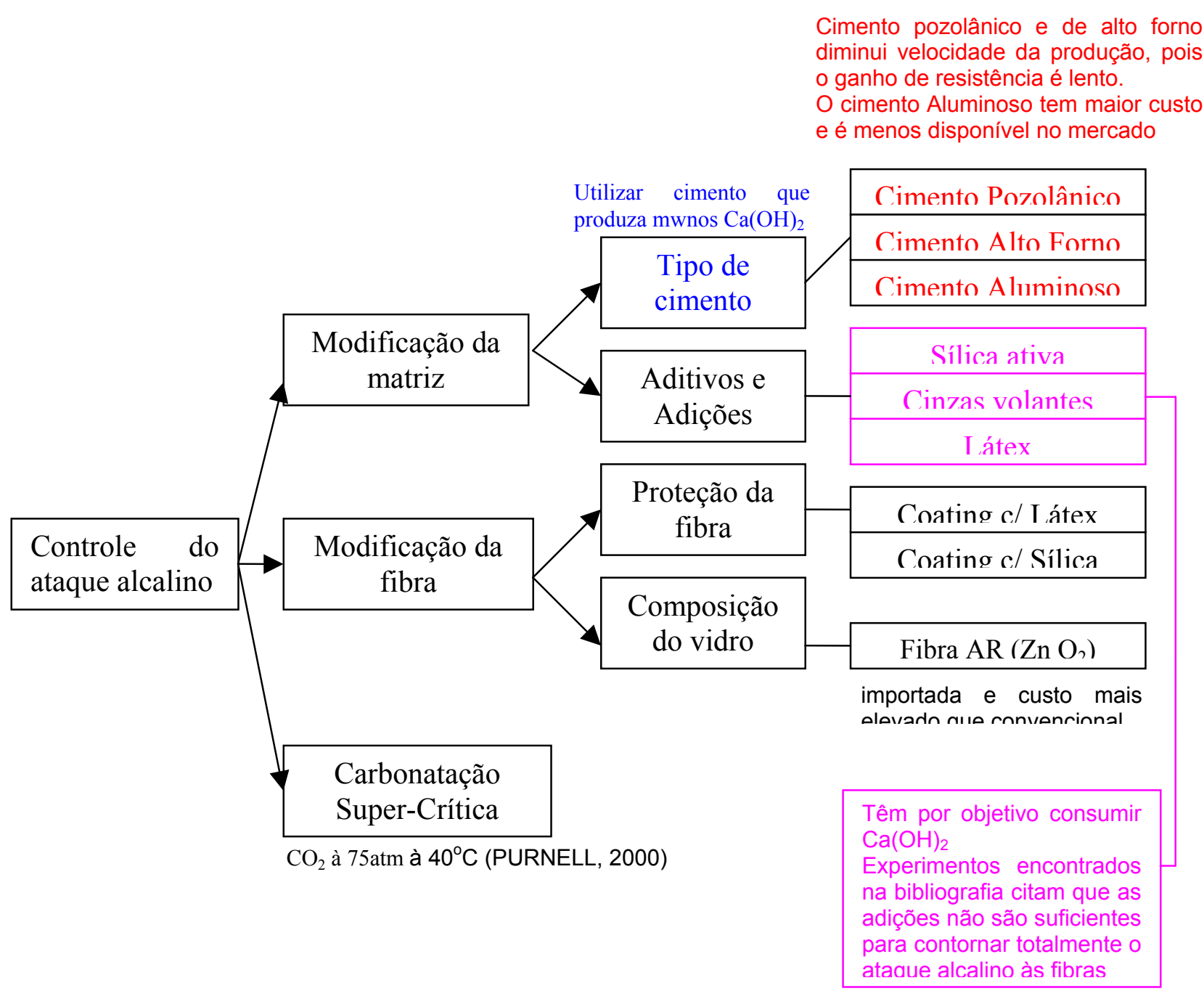

FIGURA 2.7 - Fluxograma das possíveis soluções para controle do ataque alcalino do cimento Portland às fibras de vidro 
CAPÍTULO 2

Argamassa modificada com polímero

\subsection{Preâmbulos}

Neste capítulo, estão reunidas as opiniões de vários autores em relação às matrizes de cimento modificadas com polímeros e às características desses materiais, além de suas interferências nas propriedades mecânicas e físicas nestas. Apresentamse algumas noções gerais sobre polímeros, sobre látex e sua utilização na modificação de argamassas e concretos.

\subsection{Noções Gerais sobre Polímeros}

Macromoléculas são moléculas que se tornam muito grandes, contendo um número de átomos encadeados superior a uma centena, podendo atingir valor ilimitado. As propriedades dessas macromoléculas ganham características peculiares, mais dominantes do que as características que decorrem da natureza química dos átomos que as constituem ou dos grupamentos funcionais presentes. As propriedades decorrem de interações envolvendo segmentos da mesma macromolécula ou de outras; a forma e o comprimento das ramificações presentes na cadeia macromolecular também têm papel importante. Pontes de hidrogênio e interações dipolo-dipolo, ao lado de forças de van der Waals, atuando nessas macromoléculas no estado sólido, criam resistência muito maior do que no caso de moléculas de cadeia curta. (MANO, 1985)

Ainda, segundo o mesmo autor, as interações entre moléculas de alto peso molecular acarretam um pronunciado aumento da viscosidade quando em solução e, após evaporação do solvente, observa-se a formação de filmes, característica dos látex utilizados nas emulsões que, aliás, é um dos meios mais simples de reconhecimento de uma macromolécula: a capacidade de formação de filmes ou películas.

Polímero é uma longa molécula composta por muitas pequenas unidades (monômeros) juntadas e terminadas. O termo polímero vem do grego (poli $=$ muitos meros $=$ partes $)$. São consideradas polímeros as moléculas relativamente grandes, de 
pesos moleculares da ordem de $10^{3}$ a $10^{6}$, em cuja estrutura se encontram repetidas unidades químicas simples conhecidas como meros.

Polimerização é a reação química que conduz à formação do polímero, ou seja, a ligação de pequenas moléculas umas às outras para formar moléculas maiores.

\subsection{O que é látex}

A primeira referência ao látex deu-se no começo do século XVII, quando índios da América do Sul produziam calçados com características elásticas com látex obtidos de árvores conhecidas como seringueiras (hevea brasilienses) (WALTERS, 1987). Assim, o termo látex foi originalmente usado para designar o produto natural obtido da seringueira, constituído de partículas de borracha sólida dispersas em água.

Hoje, chama-se Látex uma suspensão coloidal do polímero em água, contendo aproximadamente cerca de $50 \%$ em peso de partículas esféricas muito pequenas de polímero, mantidas em suspensão na água por agentes tenso-ativos. (MEHTA \& MONTEIRO, 1994)

O látex pode ser concentrado ou diluído e pode receber pequenas quantidades de conservantes (para prevenir a contaminação de bactérias e melhorar a resistência final), estabilizadores e/ou anti-espumantes (para reduzir a quantidade de ar incorporado).

A Figura 3.1 apresenta os látex para utilização em concreto de cimento e polímero sugerido por STORTE (1991) e a Tabela 3.1 traz as propriedades de alguns látex polímeros. 


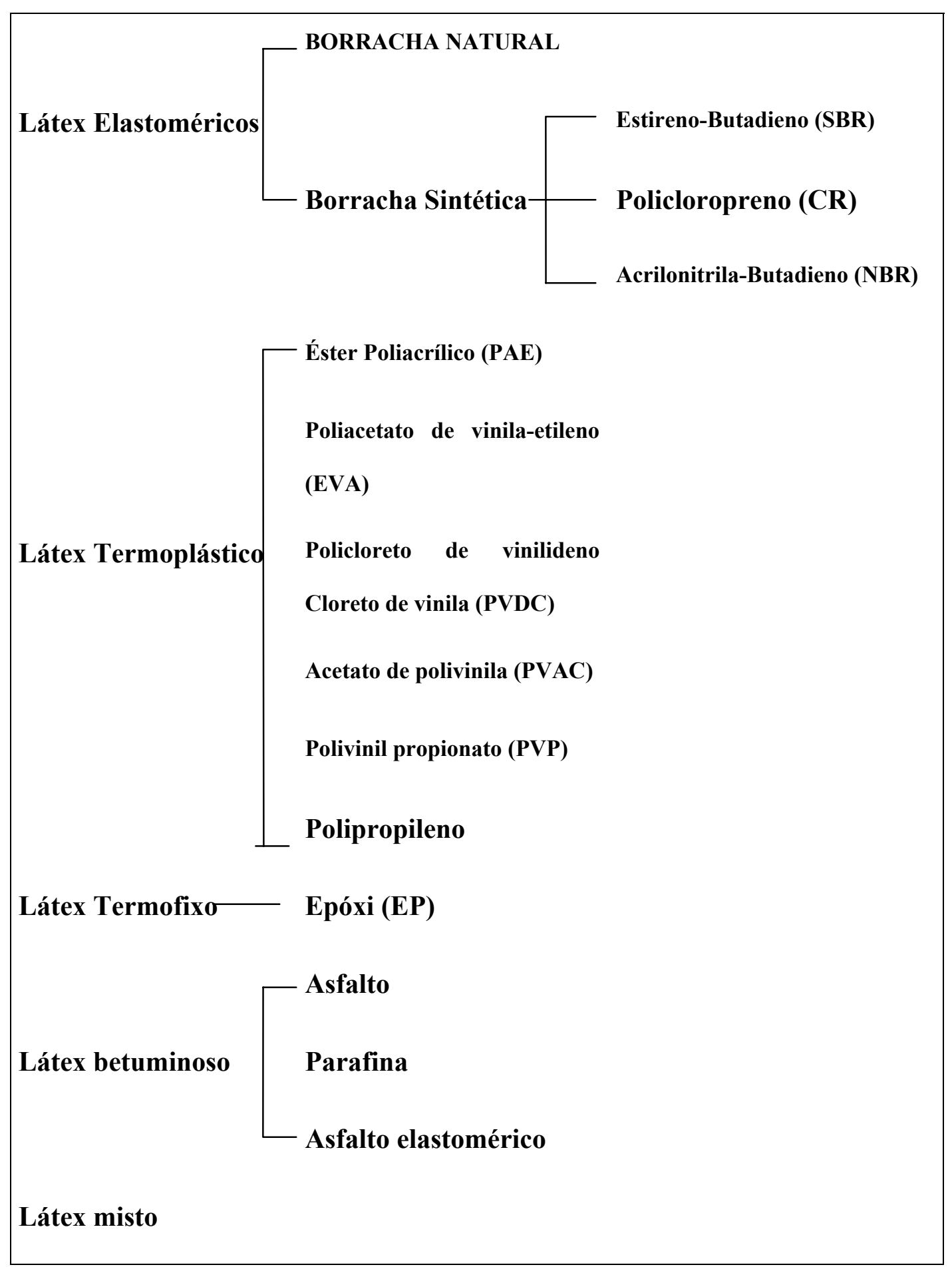

Figura 3.1 - Látex para utilização em concreto de cimento e polímero (STORTE, 1991) 
TABELA 3.1 - Propriedades de alguns látex polímeros (STORTE, 1991)

\begin{tabular}{|c|c|c|c|c|}
\hline Tipo de Polímero & $\begin{array}{c}\text { Sólidos } \\
(\%)\end{array}$ & $\begin{array}{c}\text { Massa } \\
\text { Específica } \\
\left(\mathbf{k g} / \mathrm{dm}^{3}, \mathbf{2 0}^{\circ} \mathrm{C}\right)\end{array}$ & pH & $\begin{array}{c}\text { Viscosidade } \\
\left(\text { cp, } 20^{\circ} \mathrm{C}\right)\end{array}$ \\
\hline Estireno-Butadieno (SBR) & 48 & $\mathbf{1 , 0 1}$ & 10,0 & 26 \\
\hline $\begin{array}{l}\text { Acrilonitrila-Butadieno } \\
\text { (NBR) }\end{array}$ & 41 & 1,01 & 9,1 & 27 \\
\hline Acrílico & 46 & 1,05 & 9,5 & 250 \\
\hline Acetato de Polivinila (PVA) & 50 & 1,09 & 2,5 & 17 \\
\hline Policloropreno (CR) & 42 & 1,10 & 9,0 & 10 \\
\hline
\end{tabular}

Segundo STORTE (1991), com exceção do látex de resina epóxi, os látex são produzidos pelo processo de polimerização em emulsão. $\mathrm{O}$ processo envolve a mistura de um ou mais monômeros com água, estabilizador e um catalisador. Durante o processo, ainda podem ser incorporados produtos para controlar o $\mathrm{pH}$, o tamanho das partículas, o teor de ar incorporado, etc.

\subsection{Utilização de polímeros em argamassas e concretos}

MEHTA \& MONTEIRO (1994) classificam os concretos contendo polímeros em três diferentes categorias:

a) concreto polímero (CP): formado através da polimerização de uma mistura de monômero e agregado. Esse tipo de concreto não contém outro material aglomerante a não ser o monômero;

b) concreto impregnado com polímero (CIP): é produzido por meio da impregnação ou da infiltração de um concreto endurecido de cimento Portland com um monômero e a posterior polimerização do monômero in loco;

c) concreto modificado com látex (CML): é um concreto de cimento Portland convencional, normalmente obtido pela substituição de parte da água de amassamento por látex.

Já o ACI 548.1R-92 considera o concreto polímero como todo material constituído de uma matriz de polímero e filler, preparado por meio da mistura completa da matriz polimerizável (monômero ou resina) e agregados, seguida de polimerização in situ. Ou seja, não contêm cimento Portland como aglomerante, mas este pode ser utilizado como agregado ou filler. O concreto impregnado com polímero é o concreto de cimento Portland impregnado como um monômero e posteriormente polimerizado de tal forma que o monômero tenha acesso aos espaços 
vazios dentro do material. O concreto de cimento Portland modificado com polímero é uma mistura de concreto de cimento Portland normal com polímero dissolvido em água ou uma emulsão de polímero que é adicionada durante o processo de mistura do concreto.

Tanto o Concreto Polímero como o Concreto Modificado com Látex são usados comercialmente desde os anos 50; já o Concreto Impregnado com Polímero foi desenvolvido mais tarde, por volta dos 70. O uso dos polímeros tem apresentado restrições econômicas devido a ser de alto custo, como no caso do CP e CIP, com exceção dos concretos modificados com látex (CML). Os materiais e a tecnologia da produção do CML são os mesmos que aqueles usados no concreto de cimento Portland, exceto o látex. As moléculas esféricas de polímero e o ar incorporado associado com o látex, normalmente fornecem excelente trabalhabilidade. As relações a/c estão entre 0,40 e 0,45 e os teores de cimento são da ordem de $390 \mathrm{~kg} / \mathrm{m}^{3}$ a $420 \mathrm{~kg} / \mathrm{m}^{3}$. (MEHTA \& MONTEIRO, 1994)

As características mais importantes do CML são a capacidade de forte adesão ao concreto antigo e a resistência à entrada de água e de soluções agressivas. Acredita-se que o filme de polímero revestindo os poros capilares e as microfissuras fazem um excelente trabalho, impedindo o fluxo de fluido no CML.

\subsection{Processo de formação do concreto e argamassa modificados com Látex}

Segundo OHAMA (1998), os requisitos gerais esperados na modificação do concreto e argamassa com látex são:

i) alta estabilidade química para com os íons $\mathrm{Ca}^{++}$e $\mathrm{Al}^{++}$liberados durante a hidratação do cimento;

ii) grande estabilidade mecânica;

iii) redução do ar incorporado por meio do uso de aditivos para esse fim;

iv) influência não adversa à hidratação do cimento;

v) formação de um filme de polímero contínuo em concreto ou argamassa, aderindo aos produtos de hidratação do cimento e à sílica dos agregados;

vi) excelente resistência à umidade e ao ataque do meio alcalino do cimento, aumentando a durabilidade.

A modificação com polímero das argamassas e dos concretos de cimento Portland é governada tanto pela hidratação do cimento como pelo processo de 
formação do filme de polímero em sua fase de deposição. A hidratação do cimento geralmente precede o processo de formação do filme de polímero, pela coalescência das partículas de polímero. Em ambos os casos a fase co-matriz é formada: na hidratação do cimento e no processo de formação do filme de polímero. A fase comatriz é geralmente formada de acordo com o modelo simplificado mostrado na

Figura 3.2.

(a) imediatamente após a mistura

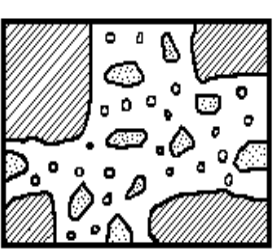

B partículas de cimento não hidratadas

- partículas de polímero

$\mathbb{W}_{\mathbb{Q}}$ la água ocupa os espaços

intersticiais]

(b) primeira passo

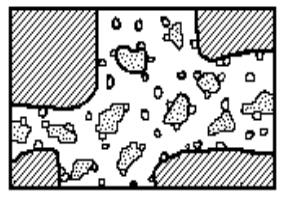

(c) segundo passo

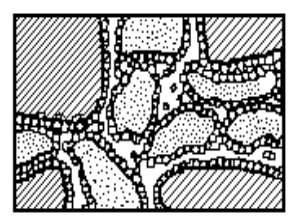

مo mistura de particulas não hidratadas de cimento, gel de cimento (nesta fase, ocorre uma deposição parcial das partículas de polímero)

(d) terceiro passo

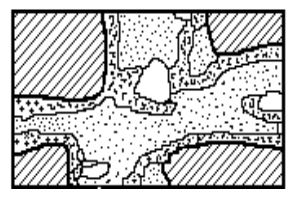

particula de cimento hidratado envolvida com filme de polimero

$5 \quad$ ar aprisionado

\section{FIGURA 3.2 - Modelo idealizado de formação do concreto de cimento polímero (OHAMA, 1998)}

Em seu trabalho, STORTE (1991) cita outras etapas para explicar a hidratação do cimento e da coalescência das partículas de polímero:

"Na pasta de cimento Portland onde as partículas de látex polímero estão dispersas de maneira uniforme, forma-se, gradualmente, pela hidratação do cimento, os géis de silicato de cálcio hidratado e a fase líquida é saturada de 
hidróxido de cálcio, enquanto as partículas de látex se depositam parcialmente nas superficies dos géis já formados e das partículas não hidratadas do cimento Portland.(...)

A medida que se desenvolve a hidratação do cimento Portland, aumenta-se o teor de gel, e as partículas do látex polímero são paulatinamente retidas nos poros capilares. Com a redução da água nos poros capilares devido ao prosseguimento da reação de hidratação do cimento Portland, as partículas de látex polímeros coalescem formando uma camada contínua nas superfícies dos géis e dos grãos de cimento não hidratados e ainda na camada de silicato de cálcio formada na superficie dos grãos dos agregados.

Por fim, com a retirada de água pela hidratação do cimento Portland, as partículas de látex polímero coalescem formando um filme contínuo ou membrana.As membranas ligam os géis hidratados e os agregados, formando uma massa monolítica em que a fase látex penetra reciprocamente através da fase do cimento hidratado." (STORTE ,1991, p. 15-16)

Ainda segundo STORTE (1991), a combinação das partículas do polímero com os silicatos de cálcio é irreversível, pois as partículas do polímero não podem ser removidas por ataque de solução de ácido clorídrico ou lavagem com água destilada, o que comprova que existe aderência química das partículas de látex estireno-butadieno.

A Figura 3.3 apresenta um modelo idealizado do processo de formação do filme de polímero na partícula de cimento hidratado. 

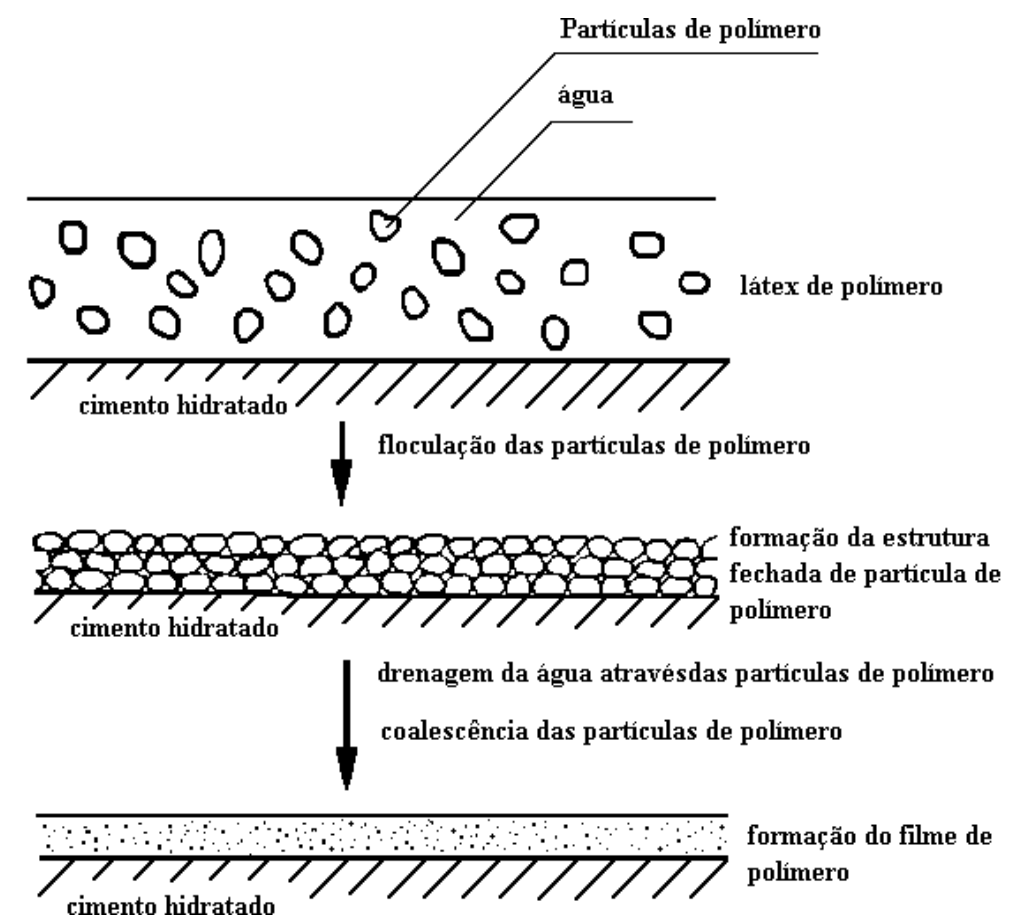

Figura 3.3 - Modelo idealizado do processo de formação do filme de polímero na partícula de cimento hidratado (STORTE,1991)

Segundo OHAMA (1998), as microfissuras na argamassa ou concreto modificados sob tensão são ligadas através dos filmes de polímero ou membranas formadas, o que previne a propagação das fissuras e, simultaneamente, desenvolve uma forte ligação entre o cimento hidratado e o agregado. Com isso, as propriedades das argamassas ou concretos de cimento Portland são geralmente melhoradas em grande escala pela modificação com o látex.

\subsection{Principais propriedades do concreto e argamassa modificados com látex}

A Tabela 3.2 apresenta as principais propriedades do concreto e argamassa modificados com polímero no estado fresco e endurecido baseado em STORTE (1991). 
Tabela 3.2 - Principais propriedades do concreto e argamassa modificados com polímero no estado fresco e endurecido (STORTE, 1991)

\begin{tabular}{|c|c|c|}
\hline \multirow{3}{*}{ Estado Fresco } & Consistência & $\begin{array}{l}\text { Boa trabalhabilidade devido ao fato de } \\
\text { partículas do látex agirem como esferas, } \\
\text { produzindo efeito plastificante e reduzindo } \\
\text { a água de amassamento }\end{array}$ \\
\hline & Ar incorporado & $\begin{array}{l}\text { São comercializados c/ anti-espumantes. O } \\
\text { ar incorporado nas argamassas é de } 5 \% \text { a } \\
10 \% \text {. Nos concretos }<2 \%\end{array}$ \\
\hline & Tempo de pega & $\begin{array}{l}\text { Maior que nas argamassas e concretos } \\
\text { convencionais. Varia c/ o tipo de látex e a } \\
\text { proporção de polímero/cimento }(\mathrm{P} / \mathrm{C}) \text {. } \\
\text { Quanto maior } \mathrm{P} / \mathrm{C} \text {, maior o tempo }\end{array}$ \\
\hline \multirow{6}{*}{ Estado Endurecido } & $\begin{array}{l}\text { Resistência à } \\
\text { Compressão }\end{array}$ & $\begin{array}{l}\text { É influenciada pelo teor e tipo de látex } \\
\text { utilizado e pela quantidade de monômeros } \\
\text { que formam o copolímero }\end{array}$ \\
\hline & $\begin{array}{c}\text { Resistência à } \\
\text { Flexão }\end{array}$ & $\begin{array}{l}\text { Maior que o convencional e influenciados } \\
\text { pelo tipo e relação } \mathrm{P} / \mathrm{C}\end{array}$ \\
\hline & $\begin{array}{c}\text { Resistência à } \\
\text { Abrasão }\end{array}$ & $\begin{array}{l}\text { Excelente desempenho se comparado ao } \\
\text { convencional. Influenciado pelo tipo e } \\
\text { relação P/C }\end{array}$ \\
\hline & $\begin{array}{c}\text { Módulo de } \\
\text { Elasticidade }\end{array}$ & $80 \%$ do concreto convencional \\
\hline & Absorção de água & Baixa, se comparado ao convencional \\
\hline & Retração & $\begin{array}{l}\text { Tende a ser menor com o incremento da } \\
\text { relação } \mathrm{P} / \mathrm{C}\end{array}$ \\
\hline
\end{tabular}

Pode-se citar como fator de limitação da utilização do polímero, para modificação dos concretos e argamassas, o pequeno tempo em aberto do látex, já que este começa a coalescer entre 15 e 30 minutos, dificultando sua utilização em situações cuja moldagem e acabamento exijam tempo maior que esse, ou exigindo que se prepare a mistura em menor quantidade e maior número de vezes. (ROSSIGNOLO, 2000)

\subsection{Cura da argamassa modificada com látex}

Segundo MEHTA \& MONTEIRO (1994), o endurecimento do látex se faz por secagem ou perda de água. A cura seca será muito importante para o CML e acredita-se que o material curado ao ar forma um filme de polímero contínuo e coerente que reveste os produtos de hidratação do cimento, as partículas de agregado e mesmo os poros capilares. 
Como visto, METHA \& MONTEIRO (1994) ressaltam a importância da cura seca para os concretos modificados com látex e não mencionam em nenhum momento a cura úmida para este.

OHАMA (1998) afirma que a melhor resistência na maioria dos concretos e argamassas modificadas com látex é obtida por meio de um razoável grau de hidratação do cimento sob condições úmidas nas primeiras idades, seguida de condições secas para promover a formação de um filme de polímero, devido a coalescência das partículas.

Também TEZUKA (1988), em relação à cura, chega à esta conclusão afirmando que, enquanto no concreto comum a condição ideal é a úmida durante longo período, no concreto de cimento e polímero, devido à formação de um filme na superfície que retém a umidade interna para garantir a hidratação contínua do cimento, é, geralmente, necessário um dia de cura úmida. Ainda ressalta que, resultados melhores são obtidos quando, após aquela cura úmida, o concreto for mantido ao ar à temperatura de $15^{\circ} \mathrm{C}$ a $27^{\circ} \mathrm{C}$.

BIJEN (1993), em seus estudos com argamassas modificadas com látex e reforçadas com fibra de vidro, cita que todas amostras de argamassa modificadas com polímero foram curadas um dia nas fôrmas de moldagem, cobertas com folhas de plástico e mantidas à $20^{\circ} \mathrm{C}$ e subseqüentemente à $20^{\circ} \mathrm{C}$ e $65 \%$ de umidade relativa.

STORTE (1991), nos seus experimentos utilizou corpos-de-prova curados durante 24 horas em câmara úmida e, os restantes, 27 dias curados ao ar.

Para ROSSIGNOLO \& AGNESINI (2000), a diminuição da permeabilidade devido à formação do filme de polímero impede a entrada de água no concreto durante o processo de cura úmida, assim como impede a perda de água para o ambiente, por isso, os processos de cura úmida não são muito eficientes neste tipo de material.

Tendo por base o exposto acima, pode-se supor que o filme formado na superfície do concreto ou argamassa modificados com látex pode substituir a pintura da superfície do concreto com uma película impermeável, muitas vezes utilizada nos processos de cura, sem fornecimento de água.

Quando se tratar de elementos esbeltos, como lajes, placas,entre outros, em que a largura e o comprimento sejam muitos maiores que a espessura, facilitando 
a dissipação do calor de hidratação do cimento e a formação do filme de polímero, a cura seca é bastante adequada. Quando se tratar de elementos em que não há predominância dimensional de nenhuma direção, como são as vigas altas e os pilares curtos, por exemplo, o uso exclusivo da cura seca deve ser avaliado. 
CAPÍTULO

Metodologia

\subsection{Planejamento Experimental}

\subsubsection{Objetivo}

O objetivo da fase experimental foi estudar a compatibilidade do uso de fibras de vidro convencionais em compósitos de cimento Portland modificados com látex Estireno-Butadieno e adição de sílica ativa, por meio da comparação dos valores de resistência à compressão axial, tração na compressão diametral, flexão e tração simples na fibra. Outro estudo refere-se à eficiência da proteção superficial da fibra de vidro contínua (roving) com látex $\mathrm{SB}$ e látex $\mathrm{SB}+\mathrm{S}$.A em relação ao meio alcalino do cimento Portland.

\subsubsection{Ensaios Preliminares}

Inicialmente realizaram-se os seguintes ensaios:

- Ensaio de Kantro ${ }^{12}$, por meio do qual desejou-se estudar os teores de aditivos superplastificantes necessários para cada tipo de cimento utilizado, sob os pontos de vista econômico e de eficiência.

- Ensaio de Consistência, realizado segundo NBR 7215/1982, pelo qual desejouse determinar o índice de consistência das diversas argamassas, variando a adição de látex SB entre $0 \%, 10 \%, 20 \%$ e $40 \%$ e o teor de fibras de vidro entre $0 \%, 0,5 \%, 1 \%$, $1.5 \%, 2 \%, 2.5 \%$ e $3 \%$ (em volume de argamassa). Por meio deste ensaio, foi

\footnotetext{
${ }^{12}$ O ensaio de Kantro, também conhecido como mini slump, consiste de um tronco de cone cujas dimensões são: altura $=6 \mathrm{~cm}$, diâmetro inferior $=4 \mathrm{~cm}$ e diâmetro superior $=2 \mathrm{~cm}$, assentado sobre uma placa de vidro plano e liso, nivelado horizontalmente e recebendo um material lubrificante. Após seu preenchimento com pasta de cimento (para cada tipo de cimento e variação de teor de aditivo SP) e posterior arrasamento, o cone é levantado, permitindo que a pasta flua sem nenhum impedimento até o seu equilíbrio em estado de repouso. A área que a projeção vertical do corpo-de-prova nesta condição abrange sobre a placa de vidro é medida com planímetro ou outro procedimento equivalente. Maiores detalhes são apresentados por BUCHER, H. R. E. (1988) e KANTRO, D. L. (1980)
} 
possível determinar o teor máximo de fibras que poderiam ser adicionadas às argamassas sem que esta tivesse a trabalhabilidade ${ }^{13}$ prejudicada.

- Ensaio de Compressão axial, realizado segundo NBR 7215/1982, para o cimento CP II E 32, variando a relação água/aglomerante, adição de látex SB (0\%, $10 \%, 20 \%$ e $40 \%)$ e do teor de fibra de vidro $(0 \%, 0,5 \%, 1 \%, 1.5 \%$ e $2 \%)$.

O ensaio de Kantro mostrou que o aditivo tipo SP 1 deveria ser utilizado nos compósitos de CP II E e CP III, em 2\% da massa de material aglomerante, mas se mostrou inadequado para amostras com CP V ARI, que teve melhor desempenho com o aditivo SP 2, em 1\% da massa de material aglomerante. A descrição do ensaio e alguns resultados obtidos podem ser vistos no ANEXO 1.

O ensaio de consistência mostrou que, para os teores de adições e aditivos utilizados, o máximo teor de fibra de vidro adicionado, dentro da trabalhabilidade desejada, foi de $2 \%$. Os resultados obtidos nos ensaios preliminares podem ser vistos no ANEXO 2.

O maior valor de resistência à compressão axial, com amostras de CP II E 32 obtido foi $38,8 \mathrm{MPa}$, daquela com $0,5 \%$ de fibra, $20 \%$ de látex, proporção aglomerante:agregado miúdo 1: 3 e relação água/ aglomerante 0,4. Os resultados obtidos nos ensaios preliminares podem ser vistos no ANEXO 3.

\subsubsection{Procedimentos}

A partir dos resultados obtidos nos ensaios preliminares, todos os compósitos tiveram sua relação água/aglomerante ${ }^{14}$ fixada em 0,4 , proporção aglomerante:agregado miúdo $=1: 2$ e teor de fibra de vidro discreta adicionada em $2 \%$ em volume de argamassa. Utilizou-se três tipos de cimento: CP II E, CP III e CP V ARI.

Sob o ponto de vista da alcalinidade, o CP III representa o cimento mais favorável para a fibra de vidro, pois contém grande quantidade de escória granulada de alto forno, de $35 \%$ a $70 \%$, em substituição ao clínquer, fazendo com que se reduza

\footnotetext{
${ }^{13}$ Adotou-se como trabalhabilidade desejada, aquela na qual fosse possível fazer a compactação dos corpos-deprova com a mesa vibratória ou soquete manual, sem que ocorresse perda da homogeneidade do compósito, tais como formação de grumos, esfarelação, etc..

${ }^{14}$ Esse valor de relação água/aglomerante foi adotado, primeiramente, devido aos resultados obtidos nos ensaios preliminares, mas também por ser bastante utilizado pelos pesquisadores que desejam um compósito com baixo consumo de água. Pode-se dizer que essa relação água/aglomerante igual a 0,4 representa um divisor entre um compósito convencional (água/aglomerante $=0,50 ; 0,60$, etc.) e de baixo consumo de água (água/aglomerante $=0,35 ; 0,25$; etc.), para um consumo de cimento fixado entre $350 \mathrm{~kg} / \mathrm{m}^{3}$ e $400 \mathrm{~kg} / \mathrm{m}^{3}$.
} 
a quantidade de Portlandita produzida. Por outro lado, apresenta um processo de endurecimento e de ganho de resistência lento, liberando baixo calor de hidratação.

No que diz respeito à alcalinidade, o CP V ARI representa o cimento mais desfavorável, para a fibra de vidro, pois contém grande teor de $\mathrm{C}_{3} \mathrm{~S}$ e nenhum teor de escória. Apresenta endurecimento rápido e alta resistência inicial, com alto calor de hidratação, além de produzir grande quantidade de Portlandita.

O CP II E representa o caso intermediário entre o CP V ARI e o CP III, pois contém de $6 \%$ a $34 \%$ de escória granulada de alto forno em substituição ao clínquer.

Moldaram-se corpos-de-prova com compósitos aqui chamados de Padrão, compostos apenas por cimento, água, superplastificante (SP), com ou sem fibras de vidro e compósitos modificados com látex e com adição de sílica ativa.

Os compósitos padrão utilizados foram de três tipos: CP II, CP III e CP V ARI.

Os compósitos modificados com látex e com adição de S.A. foram obtidos a partir dos compósitos padrão de CP III e CP V ARI, com as seguintes variações: 1) modificação com látex $\mathrm{SB}$; 2) substituição do cimento por $10 \%$ de sílica ativa (S.A.), em massa; 3) modificação com látex SB e substituição de cimento por $10 \%$ de S.A., em massa.

Os processos de cura adotados foram em câmara úmida para as amostras sem modificação com látex, e ao ar, em ambiente de laboratório (UR $\approx 65 \%$ ), para as modificadas. O tempo de cura foi de 28 dias para amostras de CP II e CP III e de 7 dias para o $\mathrm{CP} \mathrm{V}$.

Os corpos-de-prova foram submetidos a processo de hidratação convencional e de hidratação acelerada, segundo procedimento proposto por LITHERLAND et al. (1981) ${ }^{15}$.

A comparação dos valores de resistência à compressão, tração na compressão diametral, flexão e tração simples da fibra, dos corpos-de-prova submetidos a um e outro processo de hidratação, tornou possível verificar qual a intensidade de ataque do meio alcalino que cada cimento causa às fibras ou como a

\footnotetext{
${ }^{15}$ Nesta dissertação, entende-se por processo de hidratação convencional ou natural aquele cujas amostras, depois de curadas, ficaram expostas à ambiente externo e por processo de cura acelerada aquele cujas amostras, depois de curadas, foram imersas em água a temperatura determinada $\left(50^{\circ} \mathrm{C}\right.$ ou $\left.65^{\circ} \mathrm{C}\right)$.
} 
modificação com látex e a adição de sílica ativa atenuam este ataque ou protegem as fibras.

Há que se ressaltar que, os ensaios que mostram com melhor clareza a eficiência do reforço das fibras às argamassas, são aqueles cujas fibras são submetidas à tração; como no caso dos ensaios de tração na compressão diametral, de tração simples na fibra de vidro através de fibra contínua (roving) e de flexão.

Além da modificação dos compósitos com látex e adição de sílica ativa, procedeu-se o tratamento da superfície da fibra contínua (roving), com látex e uma mistura de látex e sílica ativa e, após secagem das fibras, moldaram-se placas esbeltas para ensaio à flexão, mergulhando as fibras sem proteção e as fibras protegidas com látex (SB) e uma mistura de látex e sílica ativa $(\mathrm{SB}+\mathrm{S} . \mathrm{A})$ em argamassa padrão de CP V ARI, sem adição de fibras curtas. A argamassa padrão de CP V ARI foi a escolhida pelo fato representar o caso mais crítico em relação à produção de $\mathrm{Ca}(\mathrm{OH})_{2}$ na hidratação do cimento.

\subsection{Características dos materiais utilizados}

\subsubsection{Cimento Portland}

Foram utilizados três tipos de cimento: CP II E 32, CP III e CP V ARI produzidos pela CIMINAS S.A., apresentados na Tabela 4.1 e 4.2.

TABELA 4.1 - Características dos cimentos utilizados (Fonte: CIMINAS S.A.)

\begin{tabular}{lcccc}
\hline \multicolumn{1}{c}{ Características } & Unidade & CP II E 32 & CP III & CP V ARI \\
\hline Finura de Blaine (NBR 7224/1984) & $\mathrm{cm}^{2} / \mathrm{g}$ & 3844 & 3781 & 4687 \\
Início de Pega (NBR 11581/) & min & 159 & 284 & 130 \\
Fim de Pega (NBR 11581/) & min & 226 & 386 & 210 \\
Resistência 1 dia (NBR 7215/1982) & MPa & 13.8 & 0 & 27.7 \\
Resistência 3 dias (NBR 7215/1982) & MPa & 26.5 & 18.7 & 42 \\
Resistência 7 dias (NBR 7215/1982) & MPa & 33.5 & 29.0 & 46.7 \\
Resistência 28 dias (NBR 7215/1982) & MPa & 44.2 & 38.6 & 56.1 \\
\hline
\end{tabular}


TABELA 4.2 - Análise química dos cimentos (\%) (Fonte: CIMINAS S.A.)

\begin{tabular}{lccccccccc}
\hline \multicolumn{1}{c}{ TIPO } & $\mathrm{SiO}_{2}$ & $\mathrm{Al}_{2} \mathrm{O}_{3}$ & $\mathrm{Fe}_{2} \mathrm{O}_{3}$ & $\mathrm{CaO}$ & $\mathrm{MgO}$ & $\mathrm{SO}_{3}$ & $\mathrm{CO}_{2}$ & $\mathrm{~K}_{2} \mathrm{O}$ & Res. \\
\hline CP II E 32 & 22,18 & 6,97 & 2,80 & 67,44 & 2,20 & 1,75 & 4,55 & 0,75 & 0,39 \\
CP III & 0,0 & 0,0 & 0,0 & 0,0 & 0,0 & 2,62 & 2,27 & 0,0 & 0,78 \\
CP V ARI & 19,41 & 4,99 & 3,35 & 63,83 & 0,74 & 3,09 & 2,03 & 0,57 & 0,44 \\
\hline
\end{tabular}

4.2.2. Areia

A areia utilizada na pesquisa foi natural retirada do rio Mogi Guaçu, São Carlos SP, e tem massa específica $2,63 \mathrm{~g} / \mathrm{ml}$ e massa unitária $1,49 \mathrm{~g} / \mathrm{ml}$. A composição granulométrica da areia é apresentada na Tabela 4.3 e Figura 4.1.

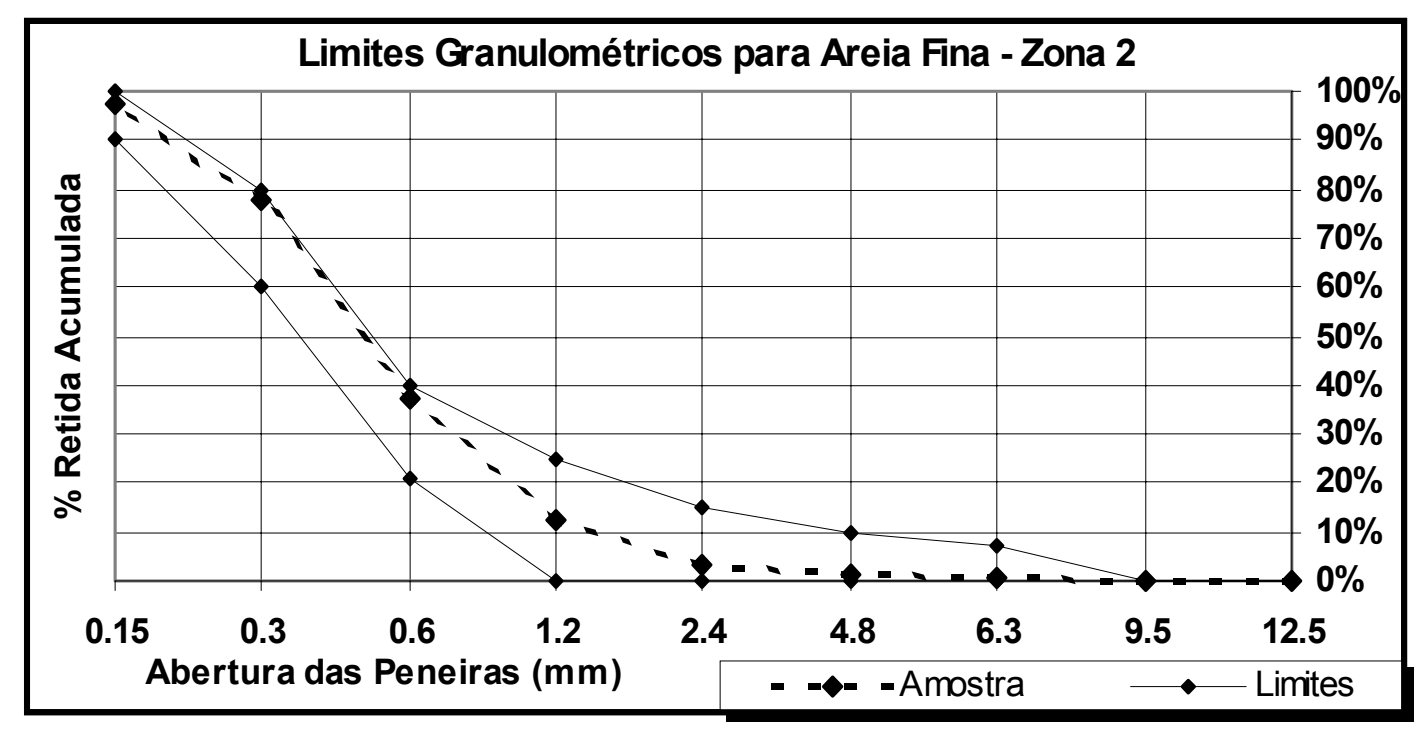

FIGURA 4.1 - Curva granulomética da areia utilizada

TABELA 4.3 - Determinação da Composição Granulométrica da Areia

\begin{tabular}{|c|c|c|c|c|c|c|}
\hline \multicolumn{7}{|c|}{ Série Normal e Série Intermediária - NBR 7217} \\
\hline \multirow{2}{*}{$\frac{P \text { Peneira }}{\#(\mathbf{m m})}$} & \multirow{2}{*}{$\begin{array}{l}\text { M1 = } \\
\text { M. Retida }\end{array}$} & \multicolumn{2}{|r|}{ M2 = } & \multicolumn{3}{|c|}{ Médias } \\
\hline & & \% Retida & M. Retida & \% Retida & \% Retida & $\%$ R. Ac. \\
\hline 12.5 & 0.0 & $0.0 \%$ & 0.0 & $0.0 \%$ & $0 \%$ & $0 \%$ \\
\hline 9.5 & 0.0 & $0.0 \%$ & 6.4 & $0.5 \%$ & $0 \%$ & $0 \%$ \\
\hline 6.3 & 3.2 & $0.3 \%$ & 9.2 & $0.8 \%$ & $1 \%$ & $1 \%$ \\
\hline 4.8 & 4.3 & $0.4 \%$ & 4.1 & $0.3 \%$ & $0 \%$ & $1 \%$ \\
\hline 2.4 & 23.5 & $2.2 \%$ & 25.6 & $2.1 \%$ & $2 \%$ & $3 \%$ \\
\hline 1.2 & 94.5 & $8.8 \%$ & 105.1 & $8.8 \%$ & $9 \%$ & $12 \%$ \\
\hline 0.6 & 274.8 & $25.5 \%$ & 301.5 & $25.3 \%$ & $25 \%$ & $37 \%$ \\
\hline 0.3 & 435.3 & $40.4 \%$ & 472.6 & $39.6 \%$ & $40 \%$ & $77 \%$ \\
\hline 0.15 & 218.1 & $20.2 \%$ & 239.2 & $20.0 \%$ & $20 \%$ & $98 \%$ \\
\hline Fundo & 25.1 & $2.3 \%$ & 29.5 & $2.5 \%$ & $2 \%$ & $100 \%$ \\
\hline Soma & 1078.8 & $100.0 \%$ & 1193.2 & $100.0 \%$ & $100 \%$ & $330 \%$ \\
\hline & & $\begin{array}{l}\text { Módulo de } \\
\text { finura: }\end{array}$ & 2.29 & $\begin{array}{r}\text { Diâmetro } \\
\text { máximo } \\
\text { rracterístico }\end{array}$ & 2.4 & $\mathrm{~mm}$ \\
\hline
\end{tabular}




\subsubsection{Sílica Ativa}

A sílica ativa utilizada foi fabricada pela Microssílica Tecnologia Indústria e Comércio Ltda., com massa específica igual a $2,21 \mathrm{~kg} / \mathrm{dm}^{3}$, massa unitária igual a $0,20 \mathrm{~kg} / \mathrm{dm}^{3}$ e superfície específica de $18.000 \mathrm{~m}^{2} / \mathrm{kg}$. A composição química da sílica é apresentada na Tabela 4.4.

TABELA 4.4 - Análise química da sílica ativa (Fonte: Microssílica)

\begin{tabular}{cccccccccc}
\hline & $\mathrm{PF}$ & $\mathrm{SiO}_{2}$ & $\mathrm{Al}_{2} \mathrm{O}_{3}$ & $\mathrm{Fe}_{2} \mathrm{O}_{3}$ & $\mathrm{CaO}$ & $\mathrm{MgO}$ & $\mathrm{SO}_{3}$ & $\mathrm{~K}_{2} \mathrm{O}$ & $\mathrm{Na}_{2} \mathrm{O}$ \\
\hline$\%$ & 3.14 & 94.3 & 0.09 & 0.10 & 0.30 & 0.43 & - & 0.83 & 0.27 \\
\hline
\end{tabular}

\subsubsection{Aditivo Superplastificante}

Foram utilizados dois diferentes tipos de aditivos superplastificantes, ambos da MBT Brasil Indústria e Comércio, cujas características estão na Tabela 4.5.

TABELA 4.5 - Propriedades e características dos aditivos superplastificantes (Fonte: MBT)

\begin{tabular}{lccc}
\hline \multicolumn{1}{c}{ Parâmetros } & Unidade & SP 1* & SP 2** \\
\hline Massa específica & g/cm & 1.11 & 1.08 \\
pH & - & 8.89 & 6.5 \\
Teor de sólidos & $\%$ & 16.49 & $<50$ \\
Aspecto & - & líquido homogêneo & Líquido homogêneo \\
Cor & - & castanho & Incolor \\
* Tipo SPA & $* *$ base em cadeias de éter policarboxílico modificado &
\end{tabular}

\subsubsection{Fibra de vidro}

Em relação à fibra de vidro, foram utilizadas fibras discretas do tipo EGlass Padrão Advantex fabricada pela OWENS-CORNING FIBERGLAS LTDA, cuja composição química, segundo o fabricante, é apresentada na Tabela 4.6.

Tabela 4.6 - Composição da fibra de vidro (Fonte: Owens Corning)

\begin{tabular}{lc}
\hline \multicolumn{1}{c}{ Composto } & Quantidade \\
\hline $\mathrm{SiO}_{2}$ & $59 \%$ \\
\hline $\mathrm{AL}_{2} \mathrm{O}_{3}$ & $13 \%$ \\
\hline $\mathrm{CaO}$ & $22 \%$ \\
\hline $\mathrm{B}_{2} \mathrm{O}_{3}$ & $5 \%$, \\
\hline $\mathrm{Mg} \mathrm{O}$ & $4 \%$ \\
\hline $\mathrm{Ca} \mathrm{F}_{2}$ & $1 \%$ \\
\hline $\mathrm{Na}_{2} \mathrm{O}+\mathrm{K}_{2} \mathrm{O}$ & $1 \%$ \\
\hline
\end{tabular}


Em relação à dimensão, comprimento de $4,5 \mathrm{~mm}$ e diâmetro de $15 \mu$, utilizado nos corpos-de-prova cilíndricos, de $6,4 \mathrm{~mm}$ e $16 \mu$, respectivamente, utilizado nas placas. Densidade de 2,62 g/ $\mathrm{cm}^{3}$ (E-Glass convencional de 2,52 g/ $\mathrm{cm}^{3}$ a $\left.2,62 \mathrm{~g} / \mathrm{cm}^{3}\right)$. A resistência à tração $\left(\right.$ a $23{ }^{\circ} \mathrm{C}$ ) de 3100 a $3800 \mathrm{MPa}$, módulo de elasticidade $80 \mathrm{GPa}$ a $81 \mathrm{GPa}$ (E-Glass convencional de $76 \mathrm{GPa}$ a $78 \mathrm{GPa}$ ). Para fibra longa, aqui chamada de roving, foram 2000 fios de 16 microns de diâmetro e 1100 Tex $(\mathrm{g} / \mathrm{km})$.

Optou-se pela utilização da fibra de vidro discreta de $6,4 \mathrm{~mm}$, pelo fato desta ter apresentado boas condições de trabalhabilidade na argamassa, enquanto uma fibra de maior comprimento, como por exemplo a de comprimento $13 \mathrm{~mm}$, que foi testada, reduziu consideravelmente essa trabalhabilidade. Por outro lado, supôs-se que o ataque químico do meio alcalino do cimento Portland ocorre com a mesma intensidade não importando o comprimento da fibra.

\subsubsection{Látex Estireno-Butadieno (SB)}

O látex utilizado na pesquisa, tanto na modificação das matrizes de cimento quanto na proteção superficial da fibra de vidro tipo roving, foi o EstirenoButadieno SB 112, fornecido pela Rhodia. A Tabela 4.7 apresenta suas características.

TABELA 4.7 - Propriedades do látex Estireno-butadieno (fonte: Rhodia)

\begin{tabular}{lc}
\hline Propriedades & Valores \\
\hline Teor de sólidos & $50 \%$ \\
Massa específica a $25^{\circ} \mathrm{C}$ & $1,02 \mathrm{~kg} / \mathrm{dm3}$ \\
Viscosidade Brookfield $\left(\mathrm{LVT} 2 / 30\right.$ a $\left.23^{\circ} \mathrm{C}\right)$ & $300 \mathrm{cps}$ \\
$\mathrm{pH}$ & 9,0 \\
Estabilizador & Aniônico \\
Aspecto & Leitoso \\
\hline
\end{tabular}

\subsection{Preparação dos corpos-de-prova}

\subsubsection{Corpos-de-prova cilíndricos}

Os compósitos foram misturados em um misturador mecânico do tipo planetário e pá de metal, de acordo com a NBR 7215/1982 e a ordem de colocação dos materiais foi a seguinte: 1) cimento; 2) parte da água; 3) SP; 4) agregado miúdo; 5) parte do látex; 6) fibra; 7) restante do látex e 8) restante da água.

Moldaram-se amostras padrão, utilizando-se os cimentos CP II - E -32, CP III e CP V - ARI. A proporção aglomerante: agregado foi de 1:2 em massa (areia 
do rio Mogi-Guaçu). A Tabela 4.8 apresenta a composição dos compósitos padrão utilizados.

TABELA 4.8 - Composição dos compósitos padrão para ensaios com corpos de prova cilíndricos

\begin{tabular}{ccccccc}
\hline Amostra & Cimento & SP 1 (\%) & SP 2 (\%) & $\begin{array}{c}\text { Látex SB } \\
(\%)\end{array}$ & S.A. (\%) & a/c \\
\hline 1 & CP II E & 2,0 & - & - & - & 0,4 \\
2 & CP III & 2,0 & - & - & - & 0,4 \\
3 & CP V ARI & - & 1,0 & - & - & 0,4 \\
\hline
\end{tabular}

A Tabela 4.9 apresenta a composição dos compósitos de CP V ARI e CP III modificados e com adição de S.A. para corpos-de-prova cilíndricos.

TABELA 4.9 - Composição dos compósitos modificados e com adição de S.A. para corpos-de-prova cilíndricos

\begin{tabular}{ccccccc}
\hline Amostra & Cimento & SP 1 (\%) & SP 2 (\%) & Látex SB (\%) & S.A. (\%) & a/c \\
\hline 1 & CP III & 2,0 & - & 20 & - & 0,4 \\
2 & CP III & 2,0 & - & - & 10 & 0,4 \\
3 & CP III & 2.0 & - & 20 & 10 & 0,4 \\
\hline 4 & CP V ARI & - & 1,0 & 20 & - & 0,4 \\
5 & CP V ARI & - & 1,0 & - & 10 & 0,4 \\
6 & CP V ARI & - & 1,0 & 20 & 10 & 0,4 \\
\hline
\end{tabular}

A compactação foi feita a cada $1 / 3$ do volume do corpo-de-prova por meio de soquete manual.

Os corpos-de-prova foram cobertos com um filme plástico para que não ocorresse perda de umidade e ficaram nos moldes por 24 horas, a seguir foram desformados e submetidos a processo de cura.

\subsubsection{Fibra-no-cimento (SIC)}

LITHERLAND et al. (1981) chamam teste da fibra-no-cimento (SIC) um pequeno bloco de pasta de cimento ou argamassa que é moldado de modo a envolver um segmento da fibra, ou vários filamentos. A fibra que ficou externa à argamassa é reforçada e protegida por uma resina de proteção (no presente trabalho usou-se silicone) e isto é continuado por uma pequena distância dentro da argamassa para proteger a fibra de dano ou flexão na extremidade do bloco. 
A FIGURA 4.2 apresenta uma representação esquemática do sistema do SIC.

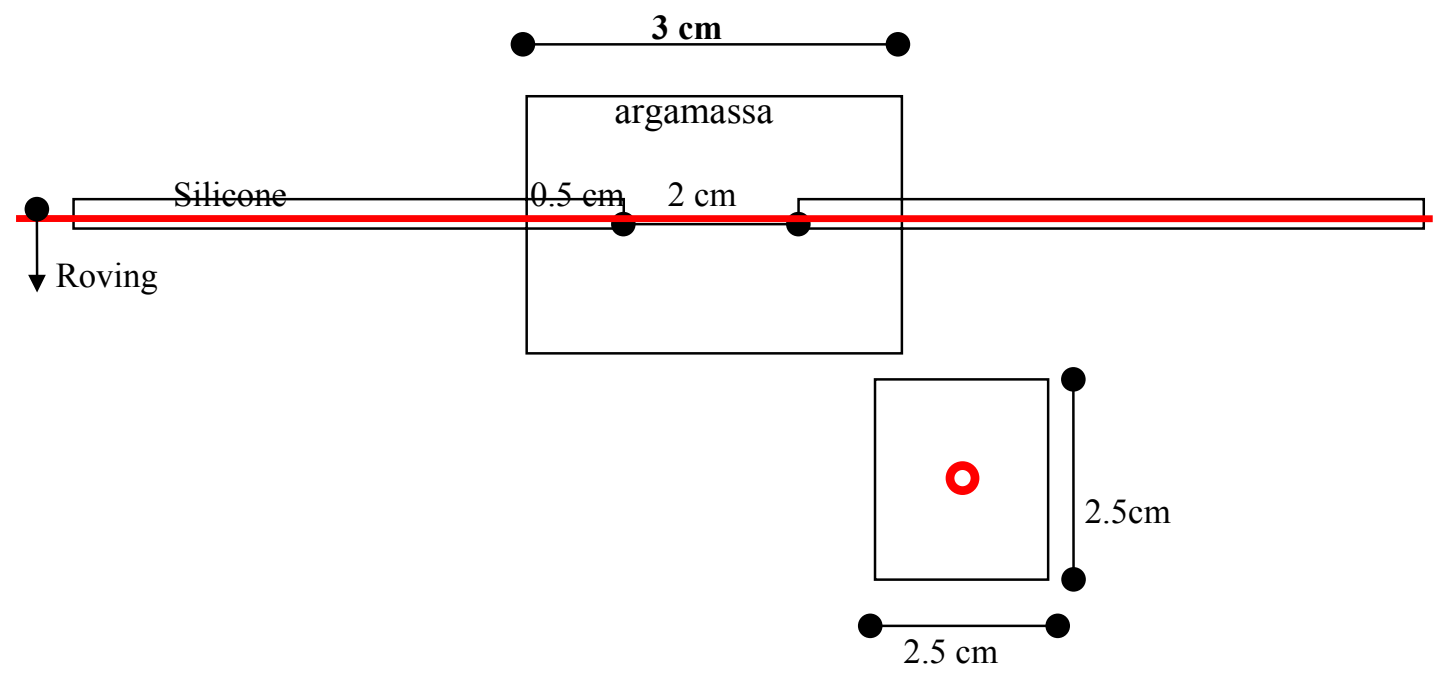

FIGURA 4.2 - Representação esquemática do SIC utilizado na pesquisa

A Figura 4.3 apresenta uma fotografia dos SIC utilizados na pesquisa.

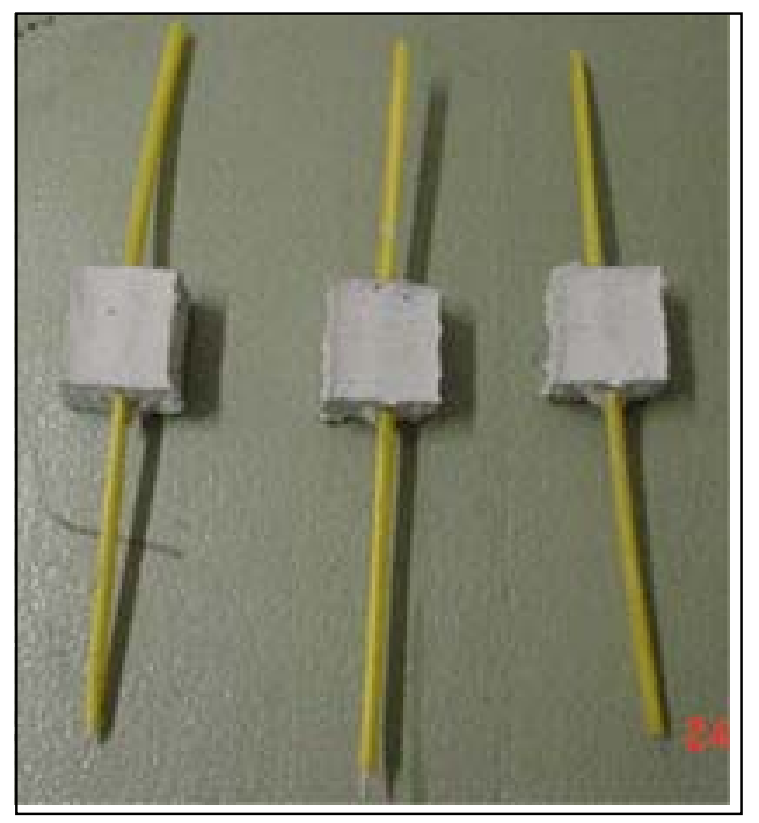

FIGURA 4.3 - Fotografia dos SIC utilizados na pesquisa

A Tabela 4.10 apresenta a composição dos compósitos padrão utilizados nos SIC.

TABELA 4.10 -Composição dos compósitos padrão para os SIC

\begin{tabular}{ccccccc}
\hline Amostra & Cimento & SP 1 (\%) & SP 2 (\%) & Látex SB (\%) & S.A. (\%) & a/c \\
\hline 1 & CP II E & 2,0 & - & - & - & 0,4 \\
2 & CP III & 2,0 & - & - & - & 0,4 \\
3 & CP V ARI & - & 1,0 & - & - & 0,4 \\
\hline
\end{tabular}

Os compósitos padrão tiveram como agregado a areia normal $0,15 \mathrm{~mm}$ em $1: 1$ em massa de material aglomerante. 
A Tabela 4.11 apresenta a composição dos compósitos de CP V ARI e CP III modificados com látex e com adição de S.A. nos SIC.

TABELA 4.11 -Composição das argamassas modificadas para os SIC

\begin{tabular}{ccccccc}
\hline Amostra & Cimento & SP 1 (\%) & SP 2 (\%) & Látex SB (\%) & S.A. (\%) & a/c \\
\hline 1 & CP III & 2.0 & - & 20 & - & 0.4 \\
2 & CP III & 2.0 & - & - & 10 & 0.4 \\
3 & CP III & 2.0 & - & 20 & 10 & 0.4 \\
\hline 4 & CP V ARI & - & 1.0 & 20 & - & 0.4 \\
5 & CP V ARI & - & 1.0 & - & 10 & 0.4 \\
6 & CP V ARI & - & 1.0 & 20 & 10 & 0.4 \\
\hline
\end{tabular}

Os compósitos de CP III e CP V ARI modificados com SB e com adição de S.A. tiveram como agregado a areia normal $0,15 \mathrm{~mm}$ em 1:1.

\subsubsection{Corpos-de-prova para ensaio à flexão (placas esbeltas)}

Os compósitos utilizados nos corpos-de-prova à flexão foram os mesmos dos corpos-de-prova cilíndricos.

Esses corpos-de-prova foram moldados em fôrmas de dimensões $\mathbf{3 5 c m} \mathbf{x}$ $5 \mathbf{c m} \times \mathbf{1 , 5} \mathrm{cm}$, com um filme plástico ao fundo e lubrificação das paredes laterais com óleo desmoldante. As fôrmas foram preenchidas com auxílio de espátula metálica e a compactação foi feita com vibrador de mesa.

A Figura 4.4 apresenta fotos mostrando a moldagem das placas para ensaio à flexão.

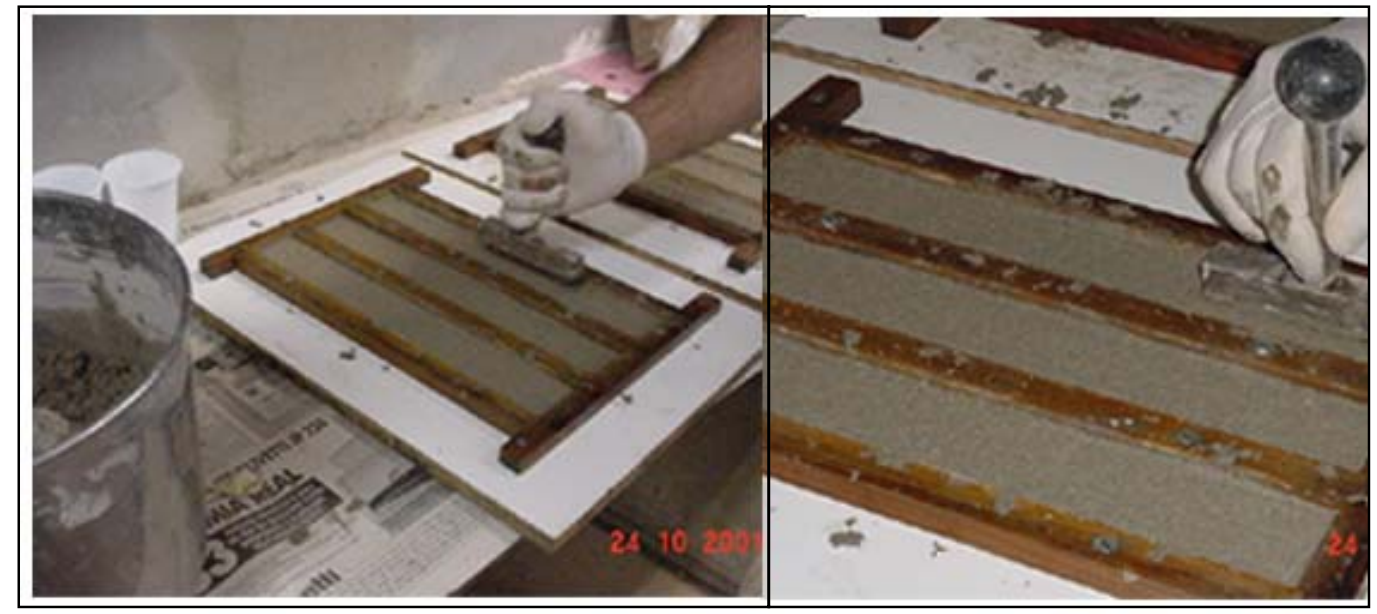

FIGURA 4.4 - Fotos da moldagem das placas para ensaio à flexão

Para o ensaio com a fibra de vidro em forma de roving com superfície protegida com SB e SB+S.A, utilizaram-se formas de dimensões $35 \mathrm{~cm} \times 5 \mathrm{~cm} \times 2 \mathrm{~cm}$. Foi utilizada uma única camada de fibras, paralelas, distanciadas de $10 \mathrm{~mm}$ umas das 
outras e com cobrimento inferior de $5 \mathrm{~mm}$ de argamassa. A Figura 4.5 apresenta os detalhes de moldagem das placas esbeltas para fibras longas.

A proteção superficial da fibra contínua (coating) foi feita emergindo-a no látex Estireno-Butadieno, que tem as mesmas especificações citadas em 4.2.6, por 10 segundos e posterior exposição ao ar, até que, após sucessivas pesagens, a massa (fibra + látex) ficasse constante.

O coating por meio da mistura de látex + sílica ativa, foi feito dissolvendo-se a sílica ativa no látex, a uma proporção de 1 parte de sílica ativa para 20 partes de látex. Os demais procedimentos foram análogos ao do coating com látex.

A composição da argamassa foi a mesma dos compósitos padrão de CP V ARI ${ }^{16}$, utilizada nos corpos-de-prova cilíndricos, sem adição de fibras picadas e com utilização de aditivo SP variando até se obter uma argamassa fluida. Os processos de cura e hidratação acelerada foram os mesmos dos corpos-de-prova cilíndricos.
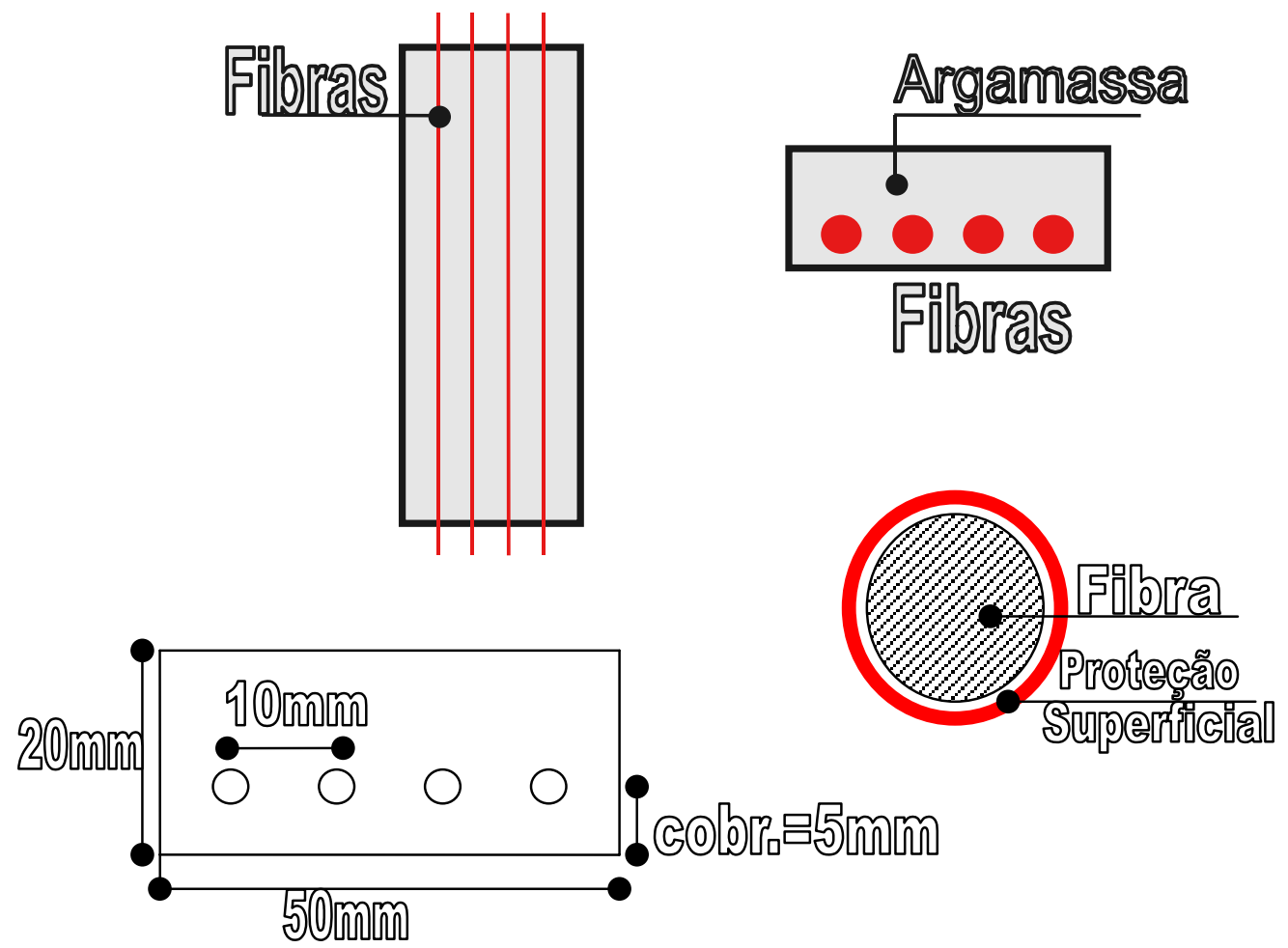

FIGURA 4.5 - Placas de compósito reforçadas com fibras contínuas

\footnotetext{
${ }^{16}$ Utilizou-se a argamassa padrão de CP V ARI, pelo fato desta representar o caso mais crítico quanto à intensidade do meio alcalino, se comparado aos demais tipos de cimento.
} 


\subsection{Descrição dos ensaios}

\subsubsection{Ensaio à compressão axial e tração na compressão diametral}

Os ensaios em corpos-de-prova cilíndricos à compressão axial e à tração na compressão diametral foram feitos de acordo com NBR 7215/1982 após processo de hidratação convencional e acelerado, no Laboratório de Construção Civil - EESC - USP. Utilizou-se sempre, no mínimo, seis ou mais corpos-de-prova cilíndricos para ensaio à compressão axial e três para tração na compressão diametral. Os valores de resistência à compressão axial e tração na compressão diametral foram calculados de acordo com a NBR 7215/1982 e NBR 7222/1983.

A Figura 4.6 traz fotografias dos corpos-de-prova cilíndricos já capeados com enxofre, sua instalação na prensa hidráulica e uma vista geral da prensa hidráulica.

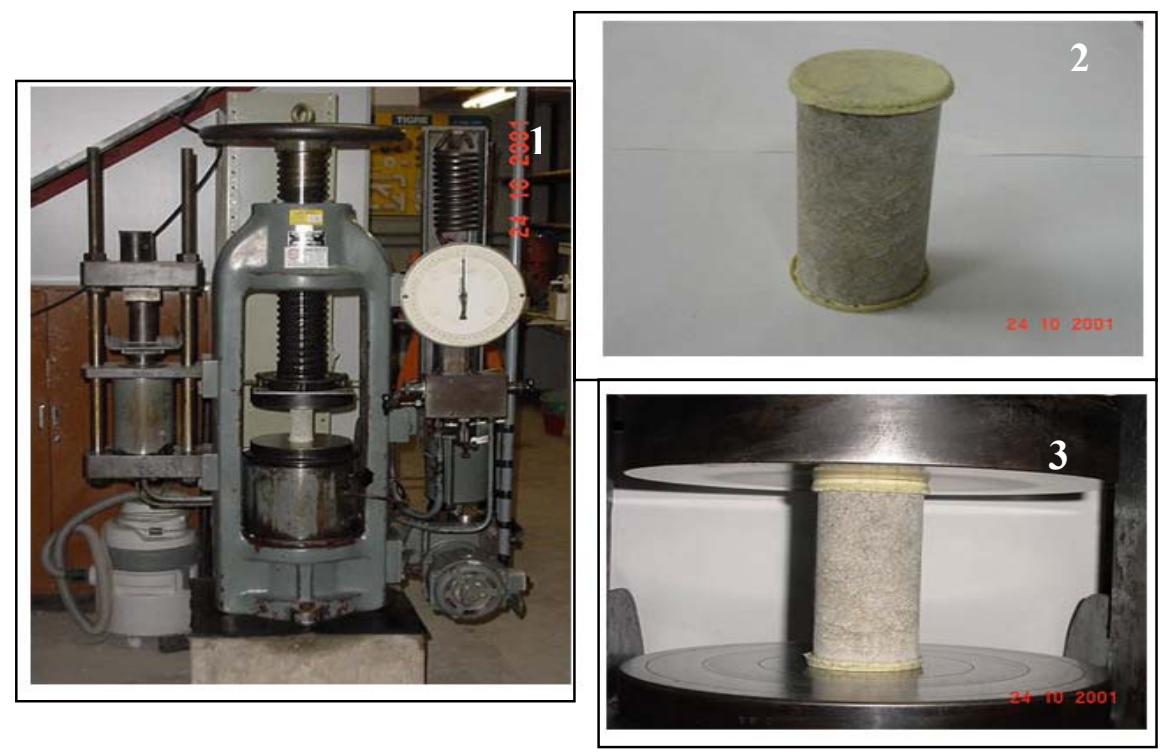

FIGURA 4.6- Fotos do ensaio de compressão axial (1) Prensa hidráulica para ensaio (2) corpo-de-prova cilíndrico já capeado (3) corpo-de-prova na prensa

\subsubsection{Ensaio à tração simples dos SIC}

O ensaio de tração simples na fibra de vidro foi realizado no Departamento de Ciência dos Materiais da EESC-USP. A velocidade de carregamento foi de $1 \mathrm{~cm} / \mathrm{min}$. A Figura 4.7 apresenta o equipamento para ensaio. 


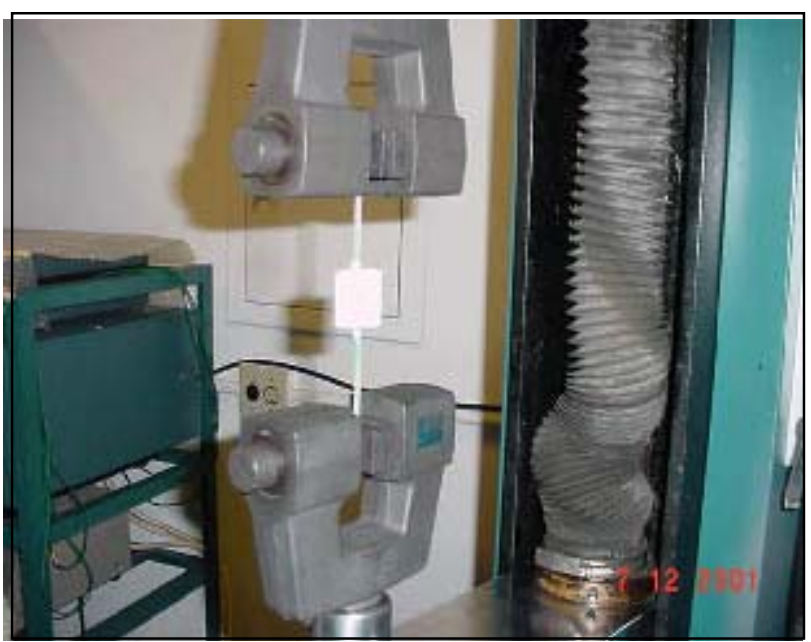

FIGURA 4.7 - SIC sendo ensaiado à tração simples

\subsubsection{Ensaio à Flexão das Placas delgadas}

O dispositivo de ensaio segue as especificações da ASTM C 947/89. A velocidade de carregamento foi controlada manualmente, pois o equipamento com controle de velocidade disponível na unidade é de 3 pontos, não adequado para esta pesquisa. A Figura 4.8 traz uma representação esquemática deste dispositivo para ensaio à flexão em 4 pontos utilizado na pesquisa.

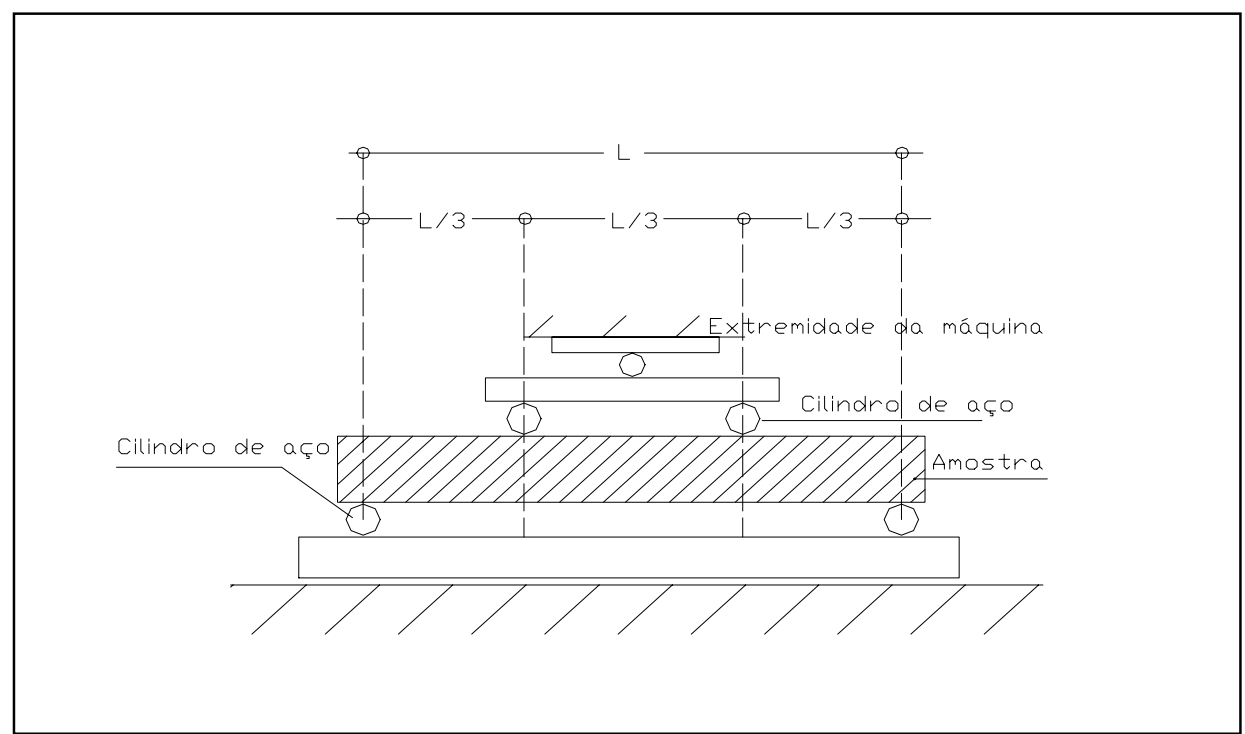

FIGURA 4.8 - Representação esquemática do ensaio de flexão $(L=33 \mathrm{~cm})$ 
A Figura 4.9 apresenta algumas fotos do equipamento de ensaio à flexão utilizado na pesquisa.

O dispositivo de ensaio estava ligado a um computador, que registrou a carga aplicada, bem como a deflexão da placa. A Figura 4.10 traz a representação de um gráfico força x deflexão.
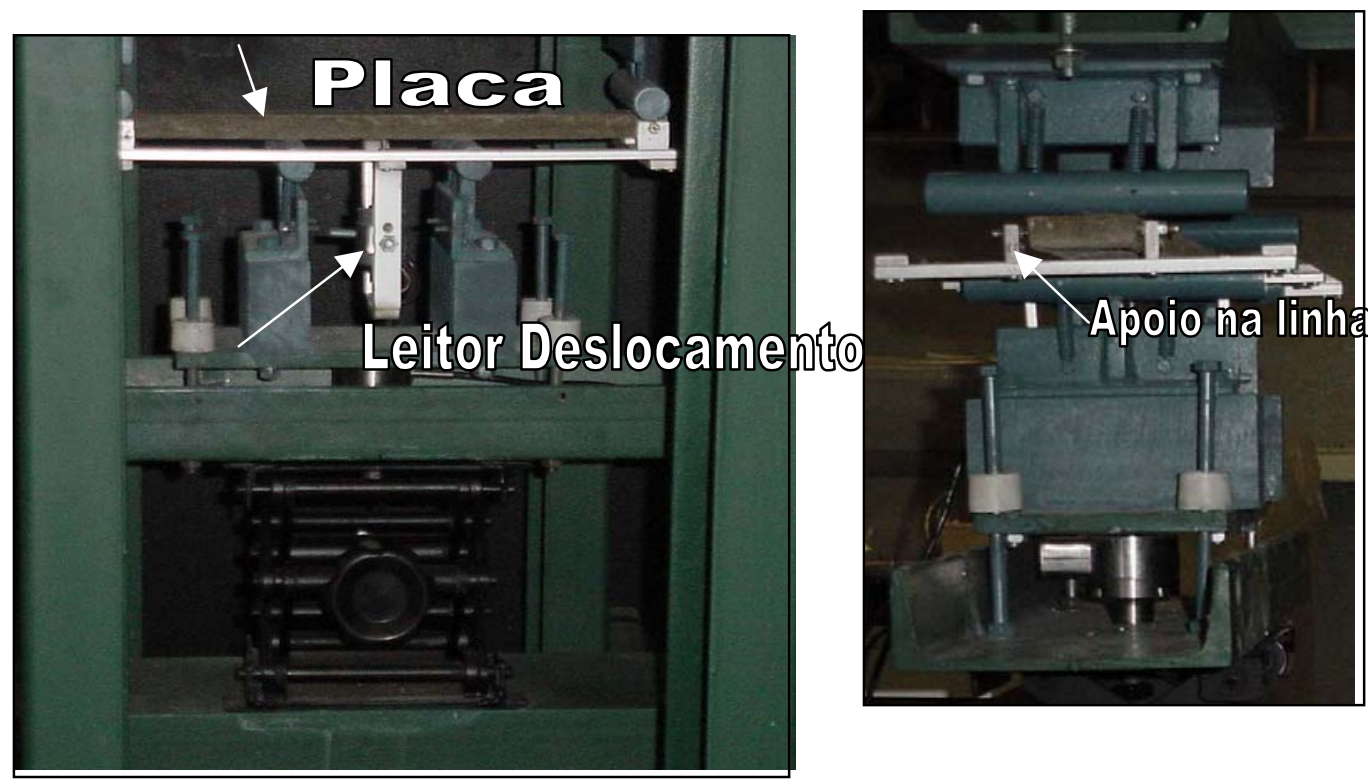

1. Apoio ha linha neứra

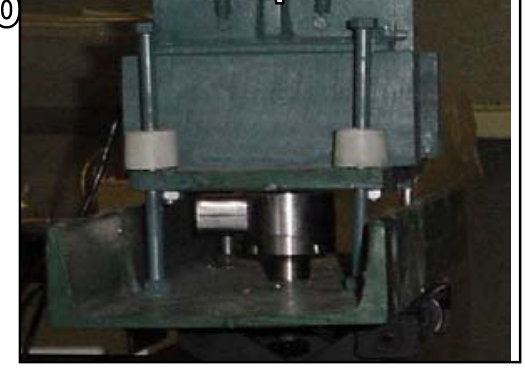

FIGURA 4.9 - Fotos do equipamento de ensaio à flexão

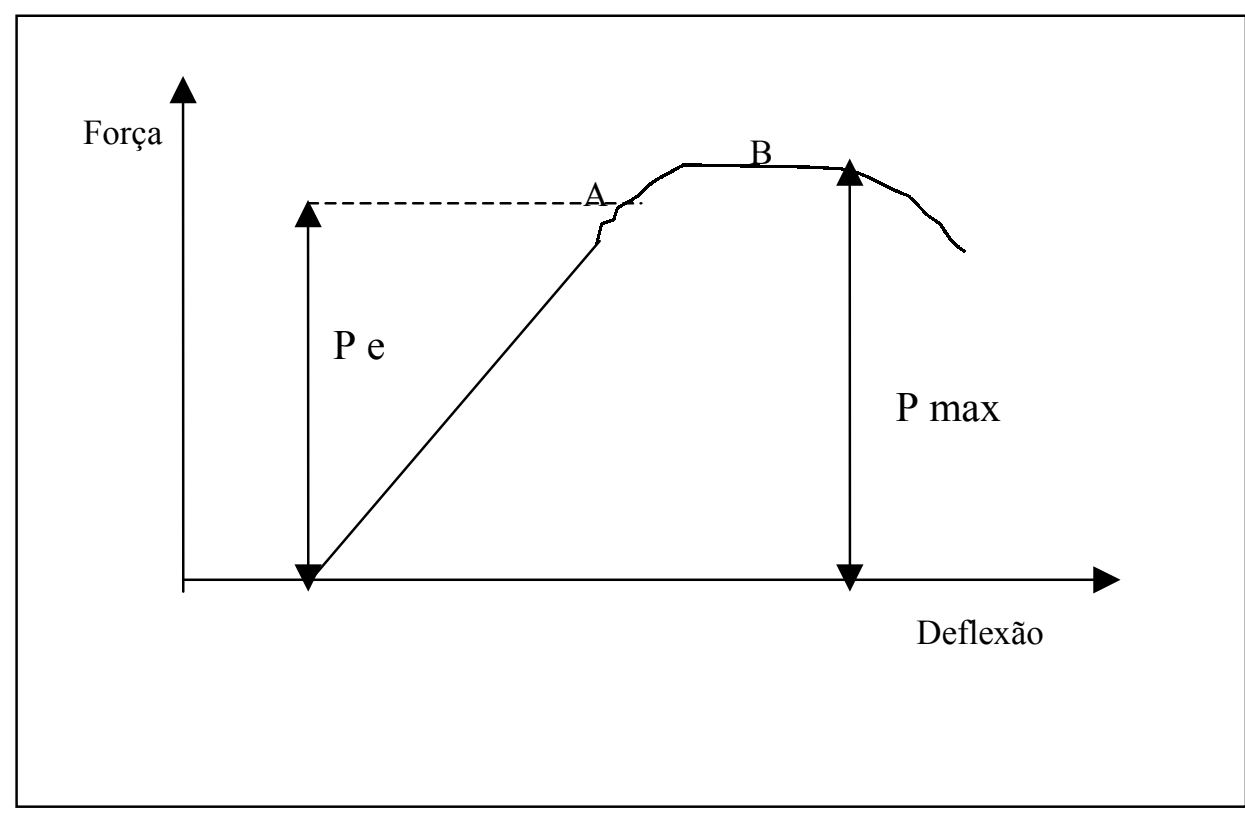

FIGURA 4.10 - Representação da curva força x deflexão (ASTM C947/89)

Para o cálculo do módulo de ruptura tem-se:

$$
\text { MOR }=\operatorname{Pmax} \times \mathbf{L} / \mathbf{b} \times \mathbf{d}^{2}
$$

Onde: 
MOR $=$ Módulo de Ruptura $(\mathrm{MPa})$

Pmax $=$ Carga máxima de ruptura $(\mathrm{N})$

$\mathrm{L}$ = Maior distância entre os pontos de apoio $(\mathrm{mm})$

$\mathrm{b}=$ largura da amostra $(\mathrm{mm})$

$\mathrm{d}=$ altura da amostra $(\mathrm{mm})$

Só foram considerados representativos aqueles ensaios cujos corpos-deprova romperam no terço central.

\subsection{Processo de Hidratação Acelerado}

A opção pelo processo de hidratação acelerado de LITHERLAND et al. (1981) deveu-se à facilidade de instalação e utilização, pois não necessita de equipamentos sofisticados e se mostrou ser adequado ao estudo do ataque alcalino às fibras de vidro, por meio de ensaios macroscópicos, além de ser utilizado no desenvolvimento de pesquisas pela grande parte dos pesquisadores no mundo. ${ }^{17}$

O equipamento é composto de uma caixa térmica de aço inoxidável, recoberta com uma camada de poliuretano e tampa com vedação. $\mathrm{O}$ aquecimento foi feito através de uma resistência ligada a um termostato regulado para estabilizar a temperatura em $50{ }^{\circ} \mathrm{C}\left( \pm 2,0{ }^{\circ} \mathrm{C}\right)$ ou $65{ }^{\circ} \mathrm{C}\left( \pm 2,0{ }^{\circ} \mathrm{C}\right)$, sendo verificado por meio de termômetros colocados em vários pontos da caixa, a distribuição homogênea do calor em todos os pontos da caixa. Cada amostra foi colocada em um recipiente de vidro ou plástico e aquecido em banho maria, de tal forma que não havia contato entre a água usada no processo de hidratação acelerada de um tipo de amostra com a de outro.

$\mathrm{O}$ período de hidratação acelerado adotado foi de 56 dias a $50^{\circ} \mathrm{C}$, e 14 dias a $65^{\circ} \mathrm{C}$. Segundo PARDELla \& DEL AGUILA (1992), 56 dias a $50^{\circ} \mathrm{C}$ correspondem a um período de hidratação convencional de 15 anos, e segundo PURNELL et al. (1999), 1 dia a $65^{\circ} \mathrm{C}$ é considerado equivalente a 12 meses de exposição natural no clima Reino Unido.

É importante ressaltar que a correspondência de dias de hidratação acelerada com a exposição em ambiente natural utilizada é válida somente para ambientes idênticos ao do Reino Unido, levando em conta condições ambientais como radiação, temperatura e umidade relativa do ar. Como não se encontrou na

\footnotetext{
${ }^{16}$ As pesquisas de LITHERLAND et al. foram utilizadas nos trabalhos de PURNELL et al (1999 e 2000), ZHANG et al. (1997), BARTOS \& ZHU (1996 e 1997), PARDELLA \& DEL AGUILA (1992), entre outros, além de basear a redação de várias normas como a ASTM e outras.
} 
literatura nenhum estudo cujas condições locais tivessem características climáticas semelhantes, ou próximas às do Brasil, adotaram-se os valores do Reino Unido, embora estas condições sejam bastante diversas das brasileiras.

\subsection{Depuração estatística dos resultados}

A depuração dos resultados de resistência à compressão, flexão e tração simples foi feita pelo critério de Chauvenet, no qual, para uma série de medidas, a probabilidade de ocorrência de um desvio de valor " $x$ " é menor do que 1 / 2 n (onde $n$ é o número de medidas). (DE MELLO, 2000)

Por exemplo: para avaliar a evolução da resistência mecânica das dosagens, utilizaram-se 6 medidas ou corpos-de-prova por idade, ou seja, $n=6$ (seis) e, portando, $\mathrm{Px}=0,08$ (desvio máximo de 8\%). Devem ser rejeitados aqueles valores que tenham desvio máximo de $\pm 8 \%$ em relação à média (entre os seis resultados por idade). A nova média passou a ser calculada com cinco resultados e, portanto, alterou o valor $\mathrm{Px}=0,1$ (desvio máximo de $\pm 10 \%$ ).

O mesmo procedimento foi adotado no desenvolvimento dos ensaios de compressão axial, de flexão e de tração simples no roving, porém, adotou-se um mínimo de 5 corpos-de-prova no ensaio à compressão, 3 corpos-de-prova para flexão e de 4 corpos-de-prova no ensaio à tração simples. 
CAPÍTULO

\section{Resultados Experimentais}

\subsection{Ensaios à compressão axial}

Este ensaio foi executado conforme a norma NBR 7215/1982, e os resultados são apresentados na Figura 5.1 e a diferença percentual entre os valores obtidos no processo de hidratação convencional e acelerado na Figura 5.2.

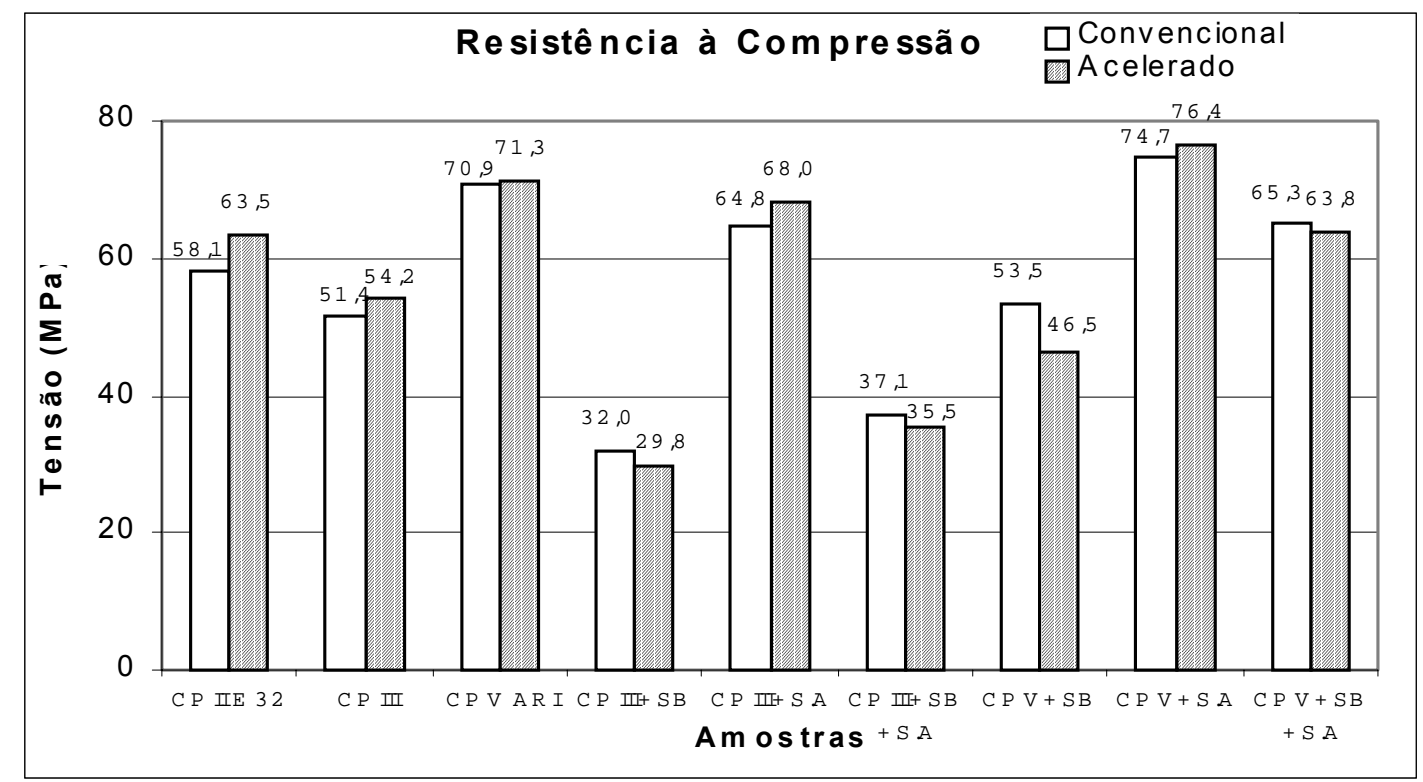

FIGURA 5.1 - Resistência à compressão axial das amostras de compósito padrão, modificadas e com adição de sílica ativa

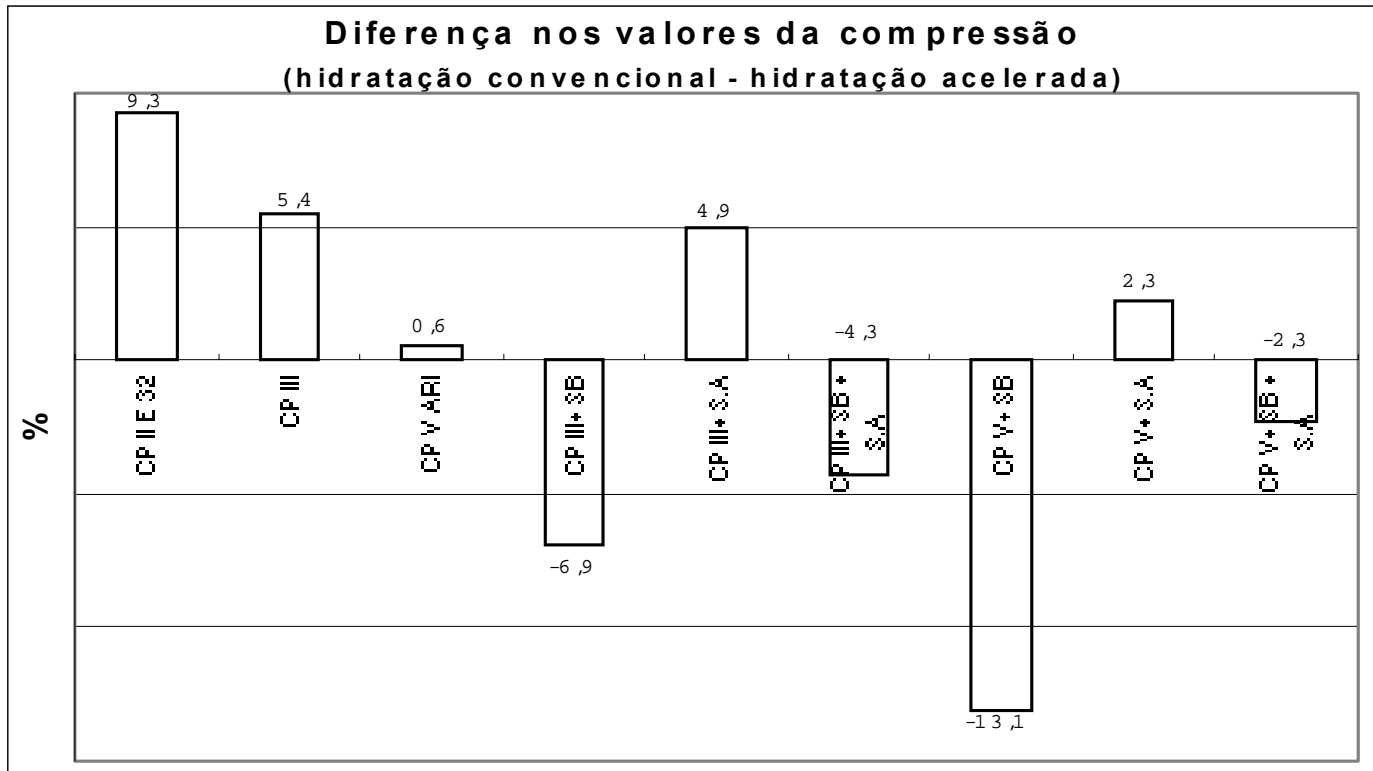

FIGURA 5.2 - Diferença dos valores de resistência à compressão (\%) 


\subsection{Ensaios à tração na compressão diametral}

Este ensaio foi executado conforme a norma NBR 7222/1982, e os resultados são apresentados na Figura 5.3 e a diferença percentual entre os valores obtidos no processo de hidratação convencional e acelerado na Figura 5.4.

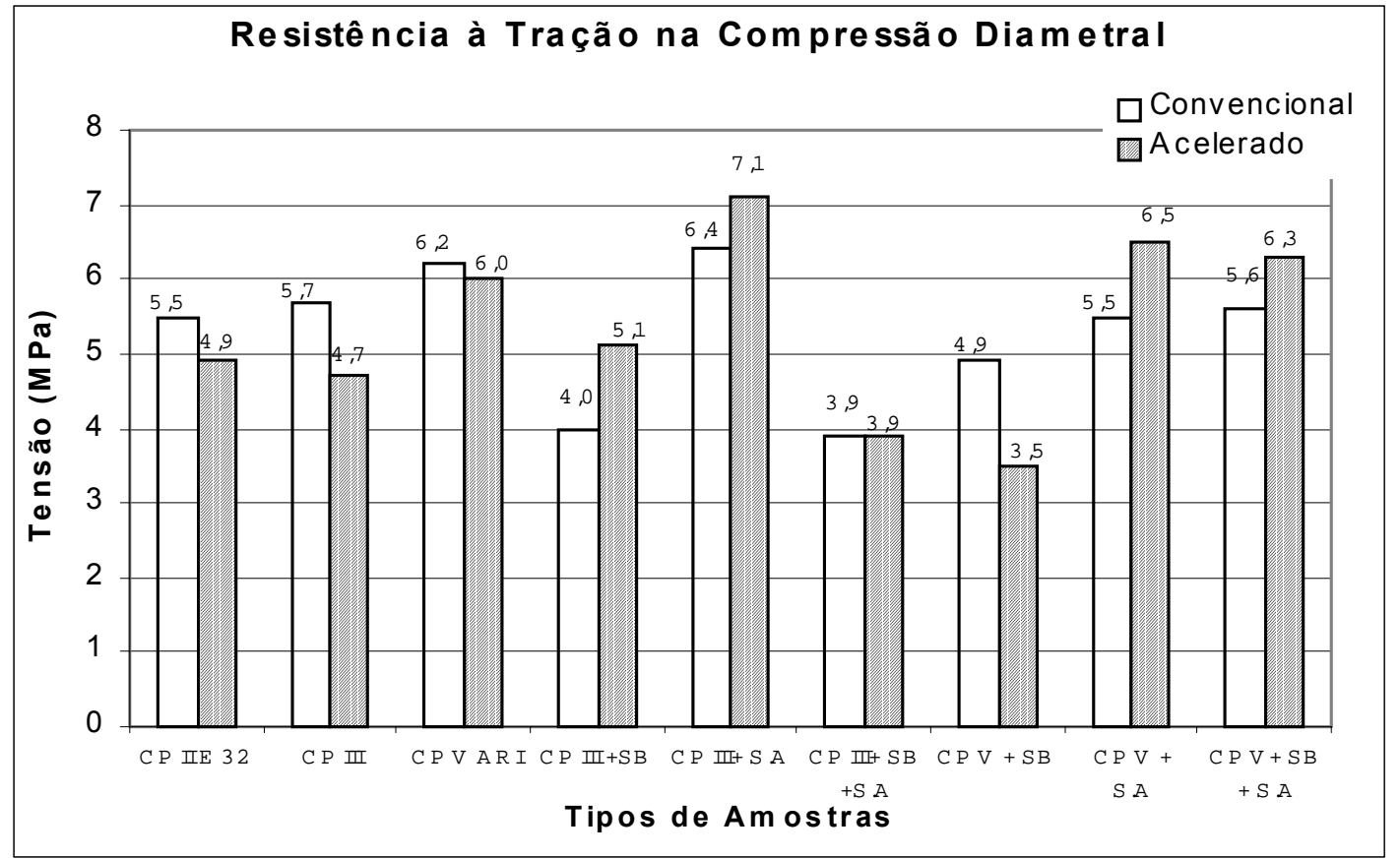

FIGURA 5.3 - Resistência à tração na compressão diametral das amostras de compósito padrão, modificadas e com adição de sílica ativa

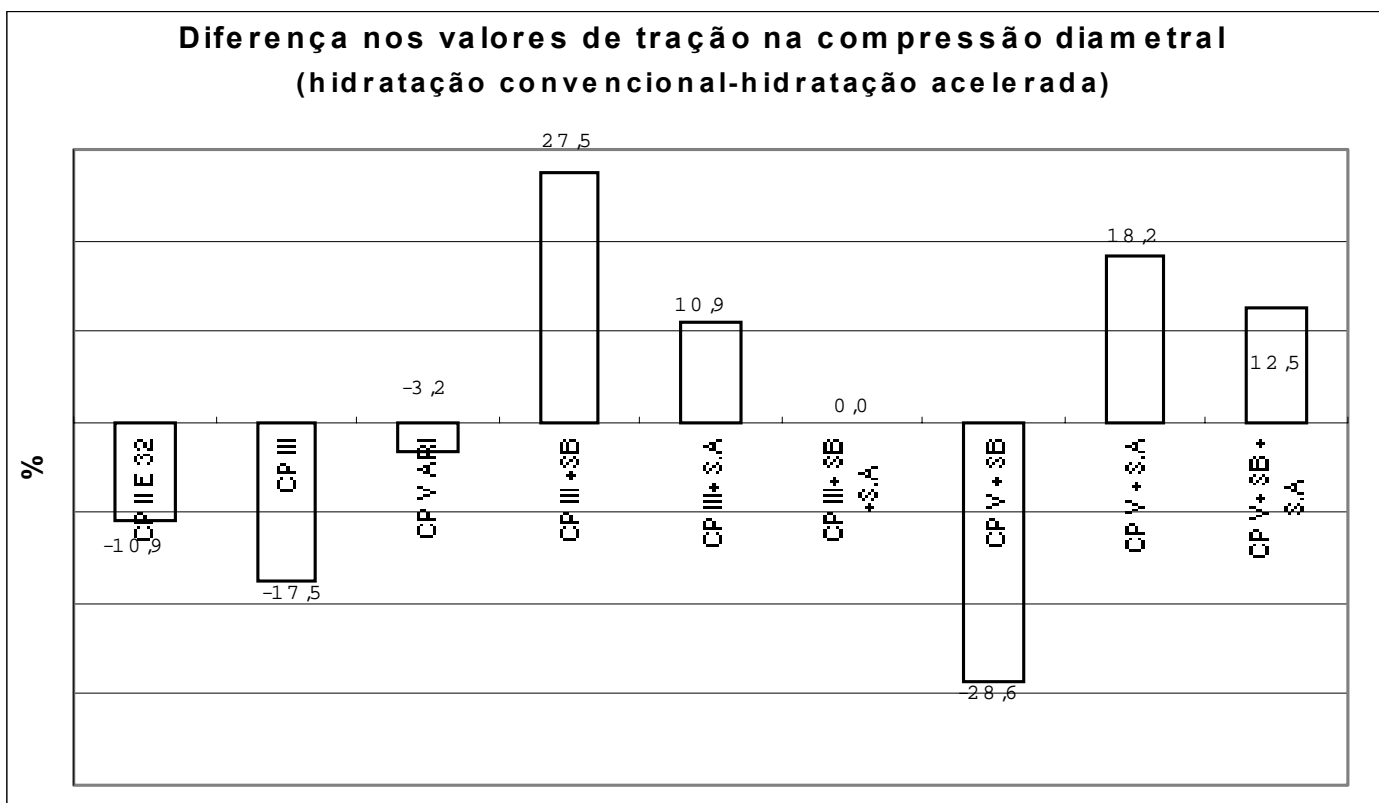

FIGURA 5.4 - Diferença de valores à resistência à tração na compressão diametral (\%) 


\subsection{Ensaios à tração simples}

O ensaio à tração simples dos SIC's foram feitos segundo os procedimentos propostos por LITHERLAND et al. (1981) e os resultados estão na Figura 5.5 e 5.6.

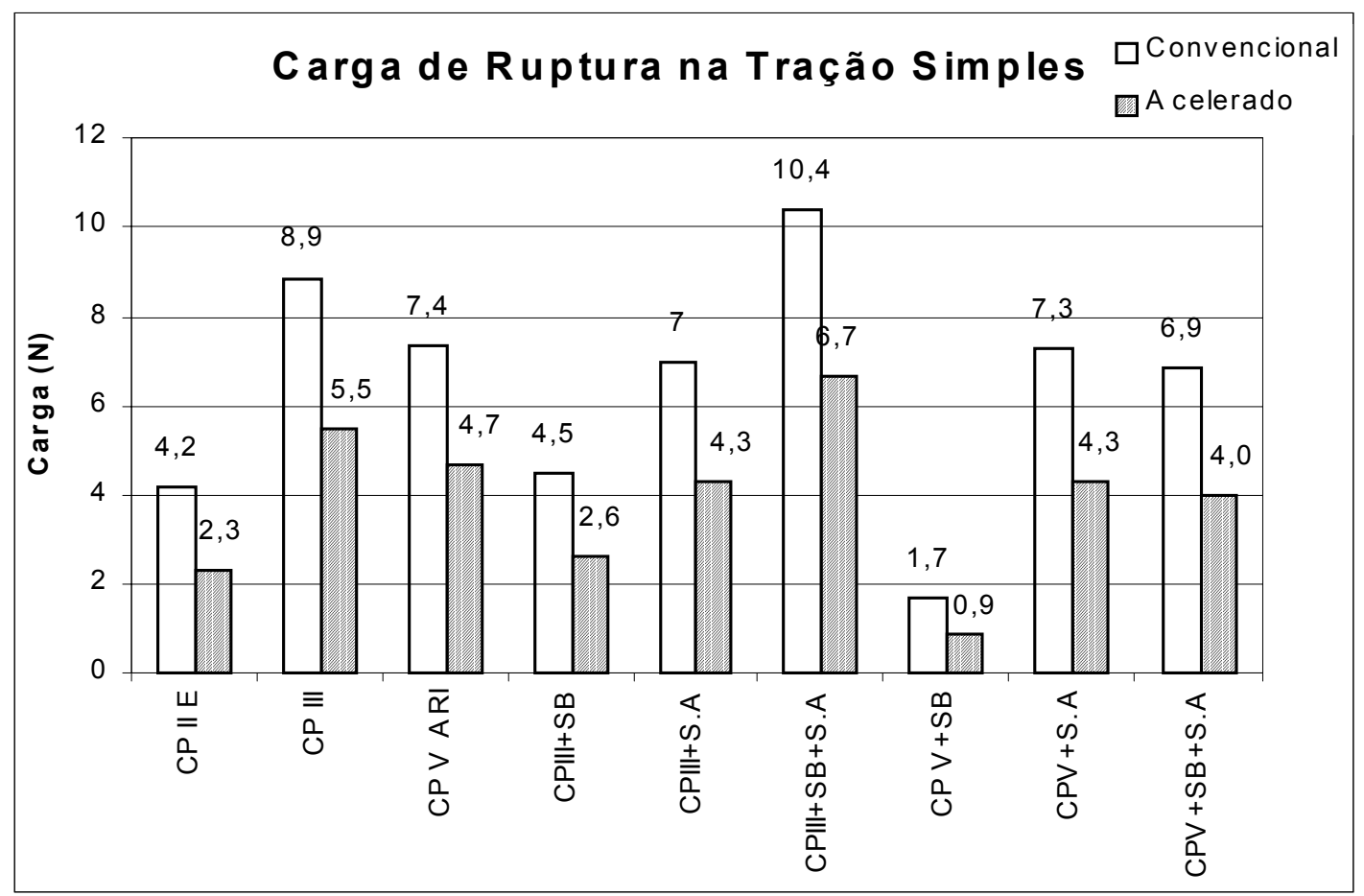

FIGURA 5.5 - Carga de ruptura à tração simples dos SIC's de argamassa padrão, modificada com látex e com adição de sílica ativa para processo de hidratação convencional e acelerado

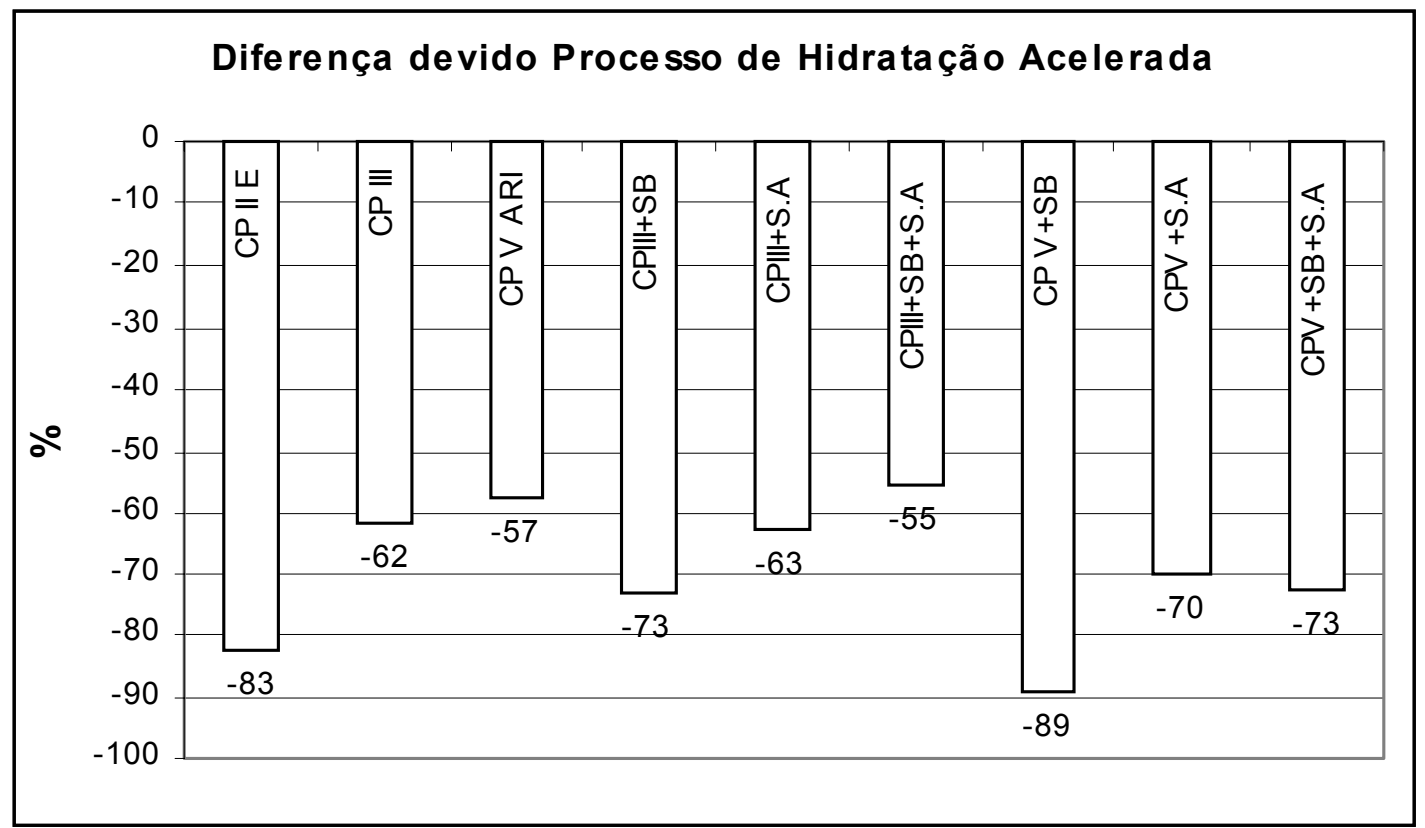

FIGURA 5.6 - Diferença dos valores do módulo de ruptura à tração simples dos SIC's (\%) 


\subsection{Ensaios à flexão}

\subsubsection{Fibras discretas}

A Figura 5.7 é apresentada abaixo como referência para comparação do comportamento das argamassas sem adição de fibras com aquelas reforçadas com fibras de vidro, curtas ou longas.

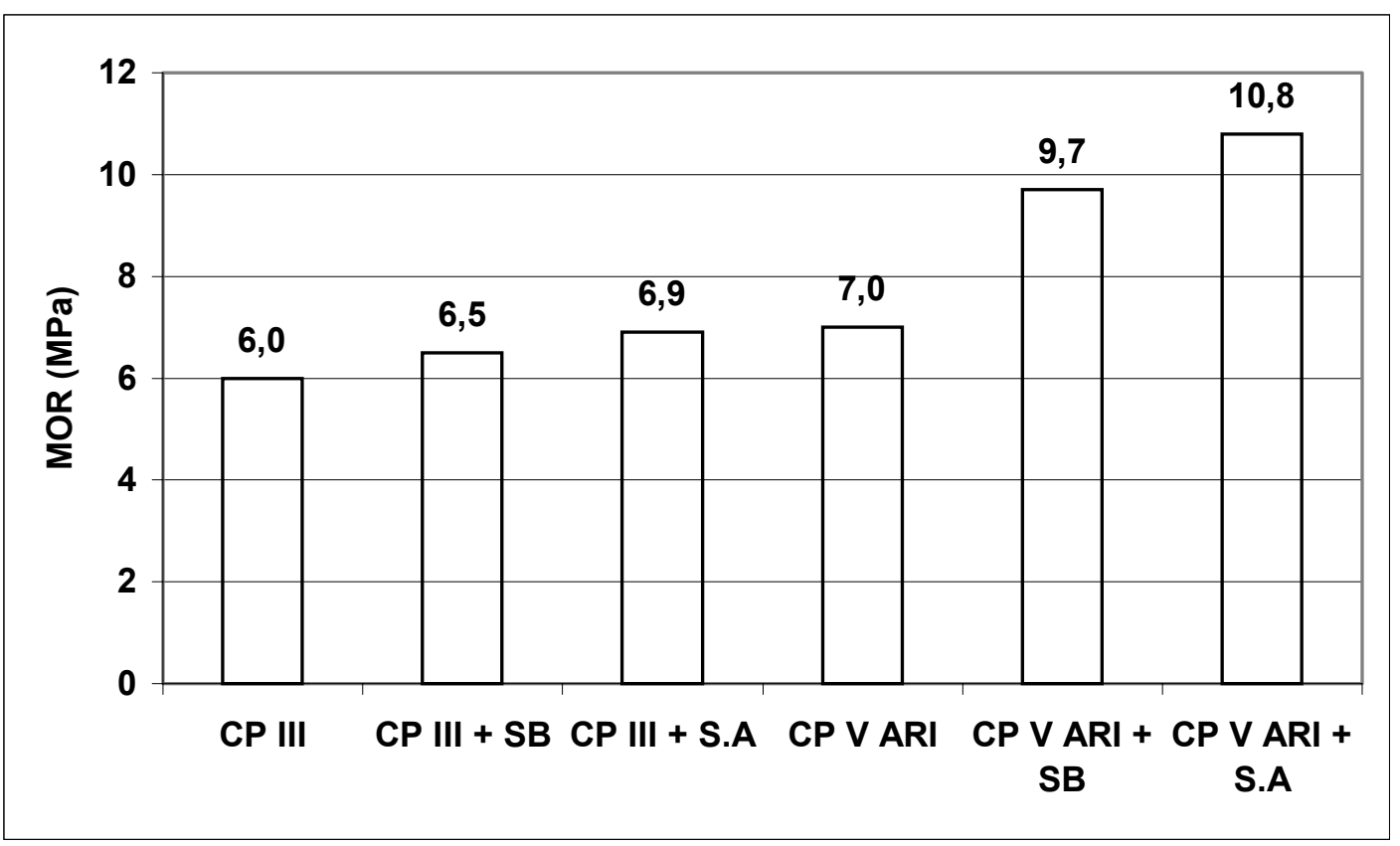

FIGURA 5.7 - Valores de módulo de ruptura à flexão para argamassas de CP III sem adição de fibras curtas 


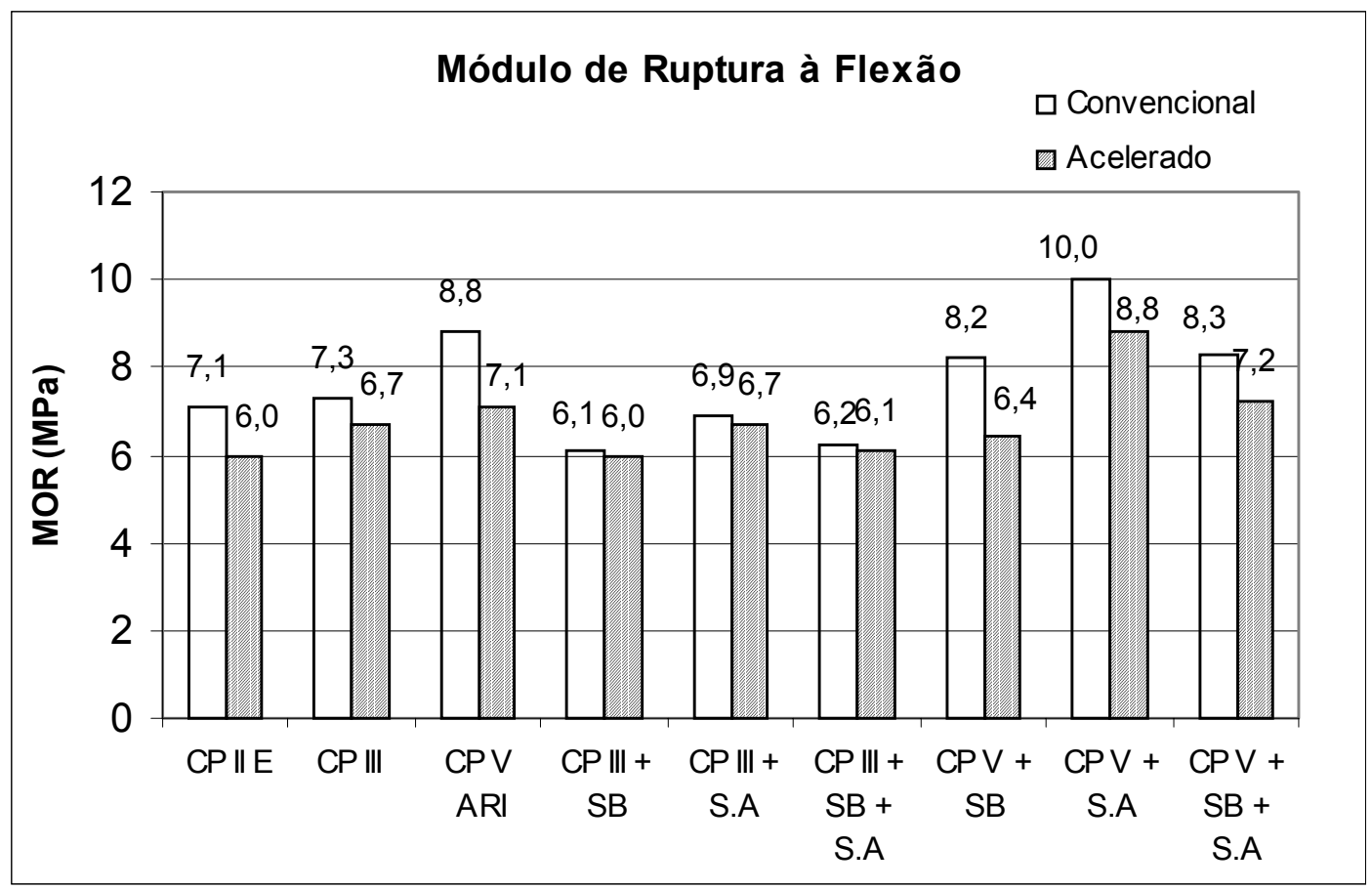

FIGURA 5.8 - Valores de módulo de ruptura à flexão para compósitos padrão, modificados com látex e com adição de sílica ativa

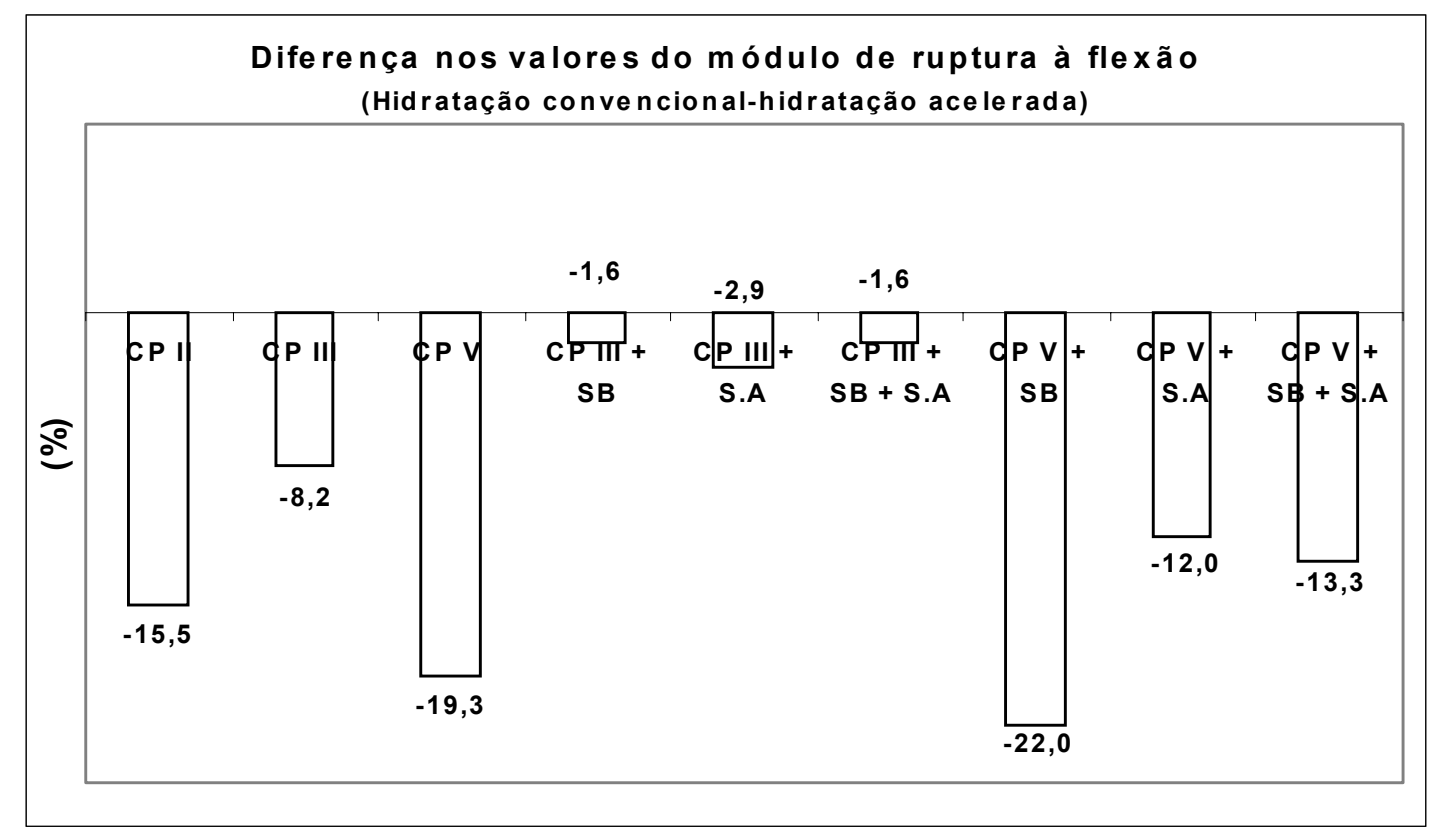

FIGURA 5.8 - Diferença percentual dos valores do módulo de ruptura à flexão das amostras de compósitos padrão, modificadas e com adição de sílica ativa, entre o processo de hidratação convencional e acelerado

Para ilustrar o comportamento dos compósitos com fibra de vidro convencional, em meio do cimento Portland, a seguir, apresenta-se alguns exemplos de curvas carga $\mathrm{x}$ deslocamento. 
CP III Convencional

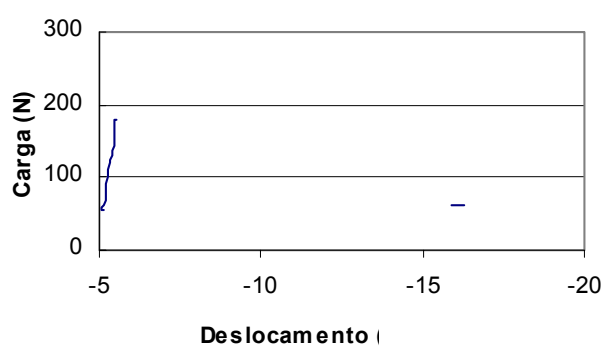

CP V Convencional

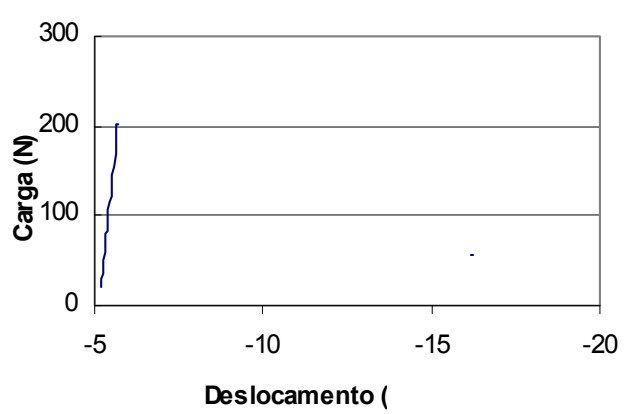

CP III Acelerado

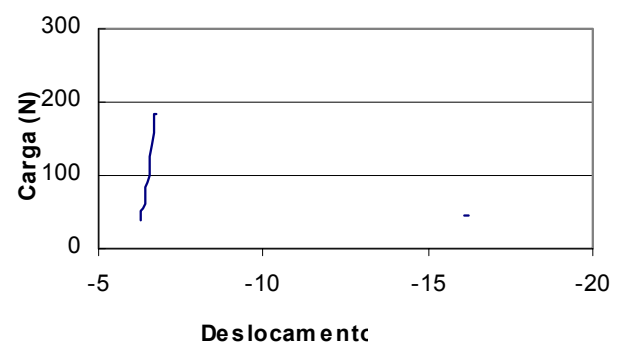

CP V Acelerado

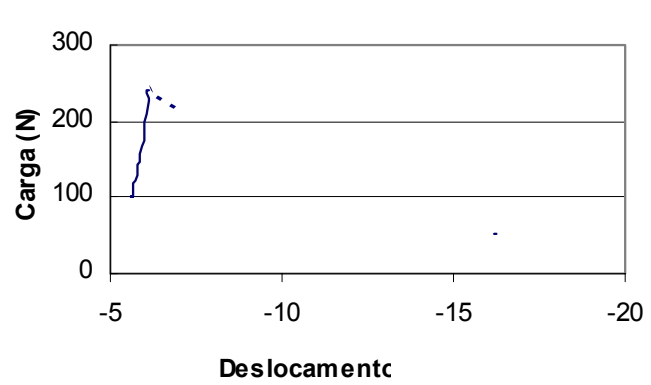

FIGURA 5.10 - Curvas de carga $(\mathrm{N}) \mathrm{x}$ deslocamento $(\mathrm{mm})$ para placas esbeltas com compósitos de cimento CP III padrão para o processo de hidratação convencional e acelerado

A Figura 5.11 apresenta as curvas de carga $\mathrm{x}$ deslocamento para os compósitos de cimento de CP III modificados com látex e com adição de sílica ativa, para o processo de hidratação convencional e acelerado. 
CP III + SB Convencional

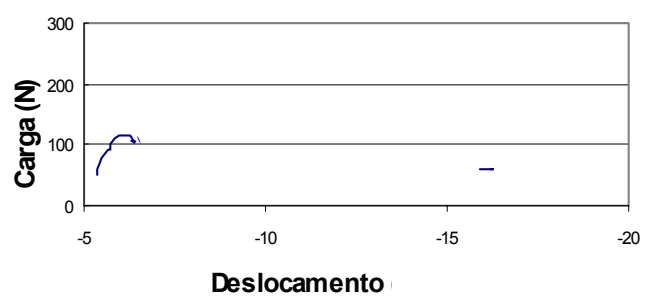

CP III + SA Convencional

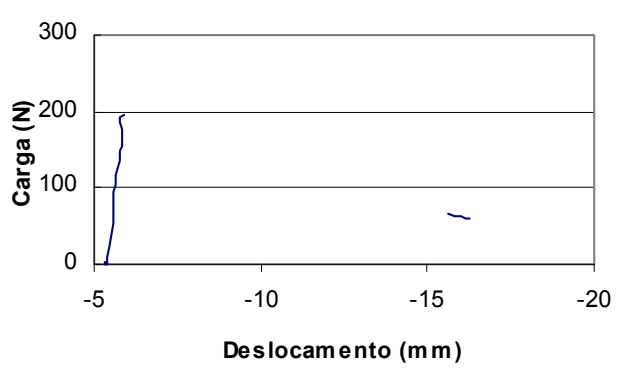

CP III + SB + SA Natural

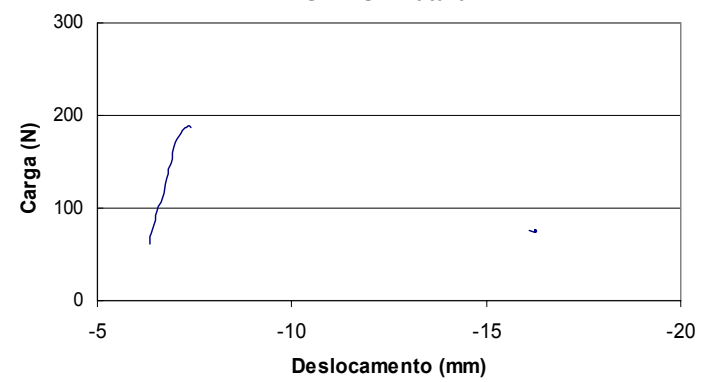

CP III + SBAcelerado

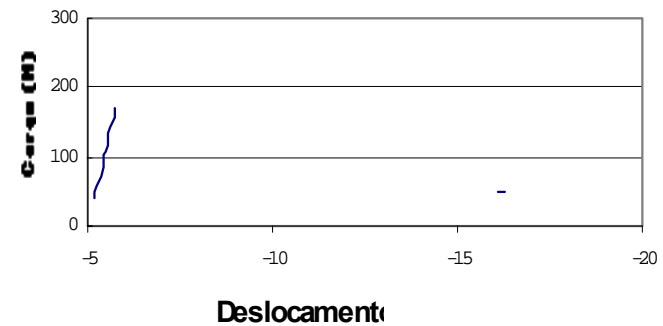

Deslocament

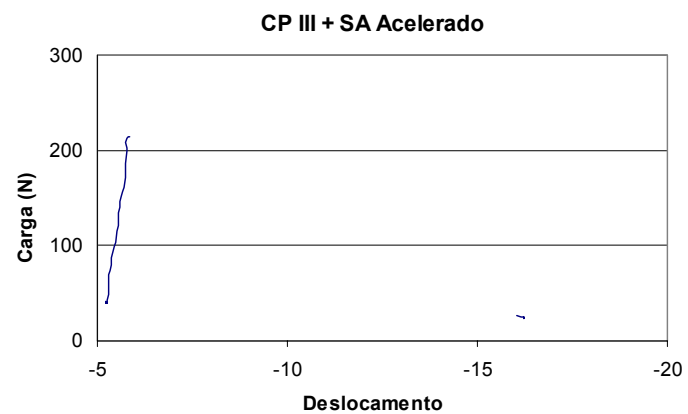

CP III + SB + SA Ace le rado

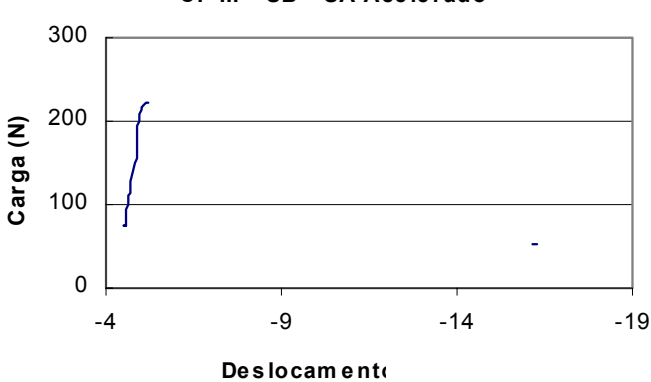

FIGURA 5.11 - Curvas de carga $(\mathrm{N}) \mathrm{x}$ deslocamento $(\mathrm{mm})$ para placas esbeltas com compósitos de CP III modificados com látex e com adição de sílica ativa para processo de hidratação convencional e acelerado

A Figura 5.12 apresenta as curvas de carga $\mathrm{x}$ deslocamento para os compósitos de cimento $\mathrm{CP} V$ ARI modificados com látex e com adição de sílica ativa, para o processo de hidratação convencional e acelerado. 
CP V + SB Convencional

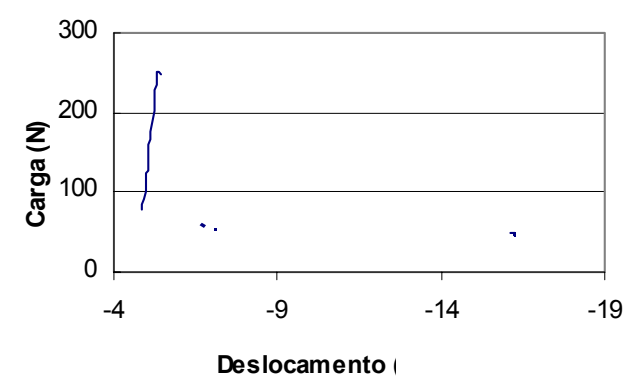

CP V + SA Convencional

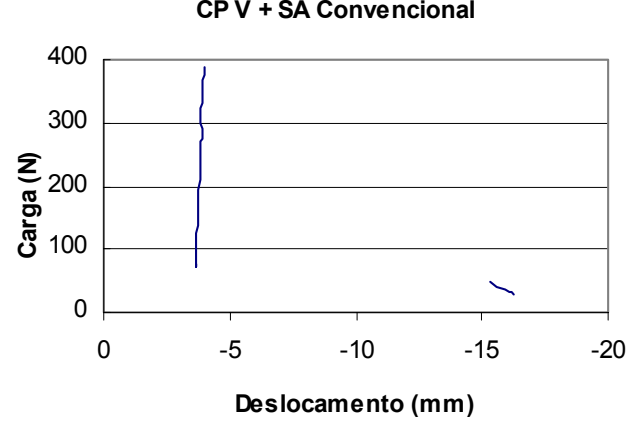

CP V + SB + SA Convencional

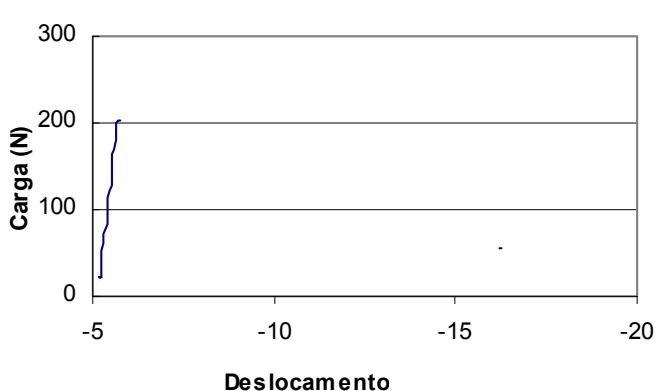

CP V + SB Ace lerado

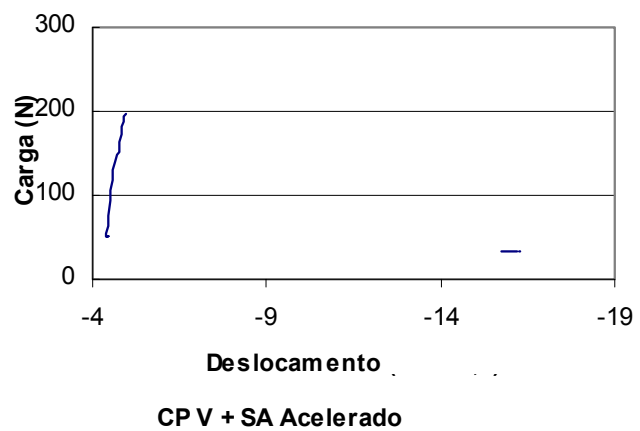

CP V + SA Acelerado

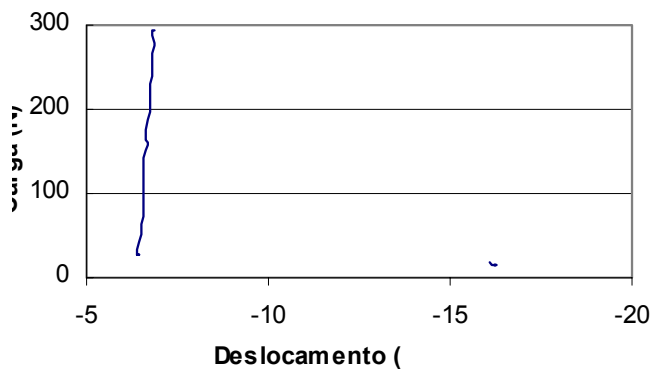

CP V + SB + SA Acelerado

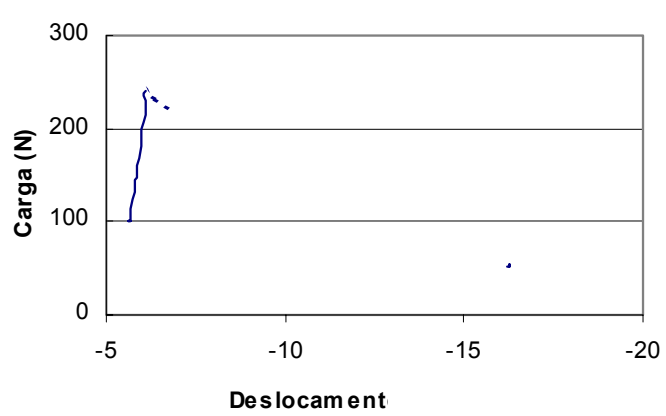

FIGURA 5.12 - Curvas de carga $(\mathrm{N}) \mathrm{x}$ deslocamento $(\mathrm{mm})$ para placas esbeltas com compósitos modificados com látex e com adição de sílica ativa de $C P \quad V$ ARI para 0 processo de hidratação convencional e acelerado

Analisando as Figuras 5.10, 5.11 e 5.12 é possível observar que a ruptura dos compósitos com fibra de vidro convencional, nas proporções utilizadas $(2 \% \mathrm{em}$ volume de argamassa), tem característica frágil, não importando o tipo de cimento utilizado ou a modificação com látex ou a adição de sílica ativa, tanto para o processo de hidratação convencional ou acelerado.

A partir desses resultados, procurou-se conferir ductilidade ao compósito, aumentando o teor de fibras curtas $(6,4 \mathrm{~mm})$. Para manter a mesma trabalhabilidade e relação água/ aglomerante, foi necessária a adição de maiores quantidades de aditivo superplastificante. 
O maior teor de fibras acrescentadas no compósito, sem comprometer a trabalhabilidade, foi de $3 \%$ do volume da argamassa e os resultados dos ensaios à flexão não apresentaram melhorias significativas.

\subsubsection{Fibras longas}

A utilização da fibra de vidro convencional na forma de roving pode conferir propriedades importantes ao compósito, pois, o reforço das argamassas é feito de forma orientada ${ }^{18}$, funcionando como um tipo de armadura contínua. Outro aspecto importante é que a sua utilização possibilita a proteção superficial da fibra de vidro com látex e sílica ativa, o que não é possível com as fibras discretas.

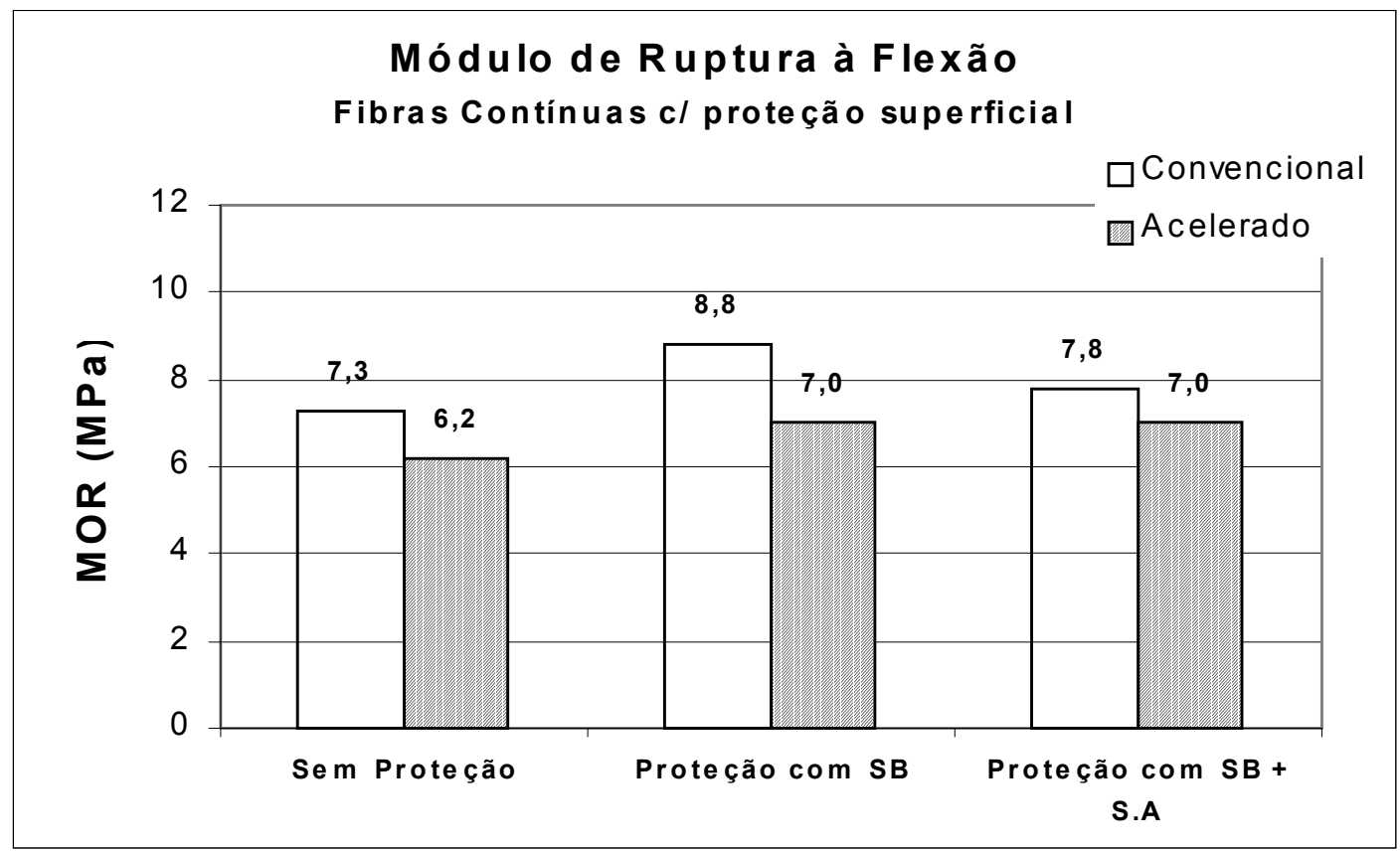

FIGURA 5.13 - Módulo de ruptura das fibras contínuas com proteção superficial comparadas àquelas sem proteção superficial para o processo de hidratação convencional e acelerado 


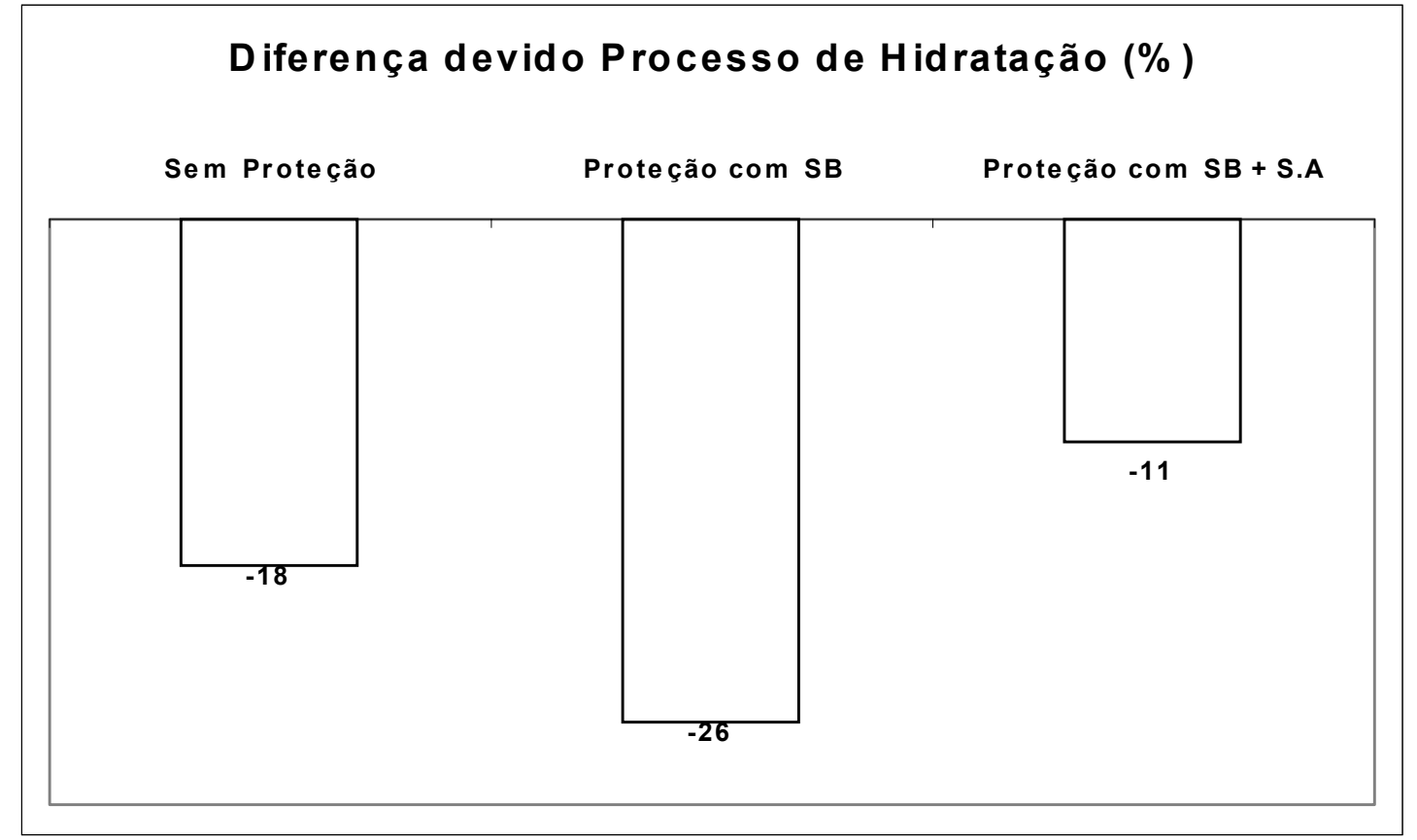

FIGURA 5.14 - Diferença no módulo de ruptura das fibras contínuas (\%)
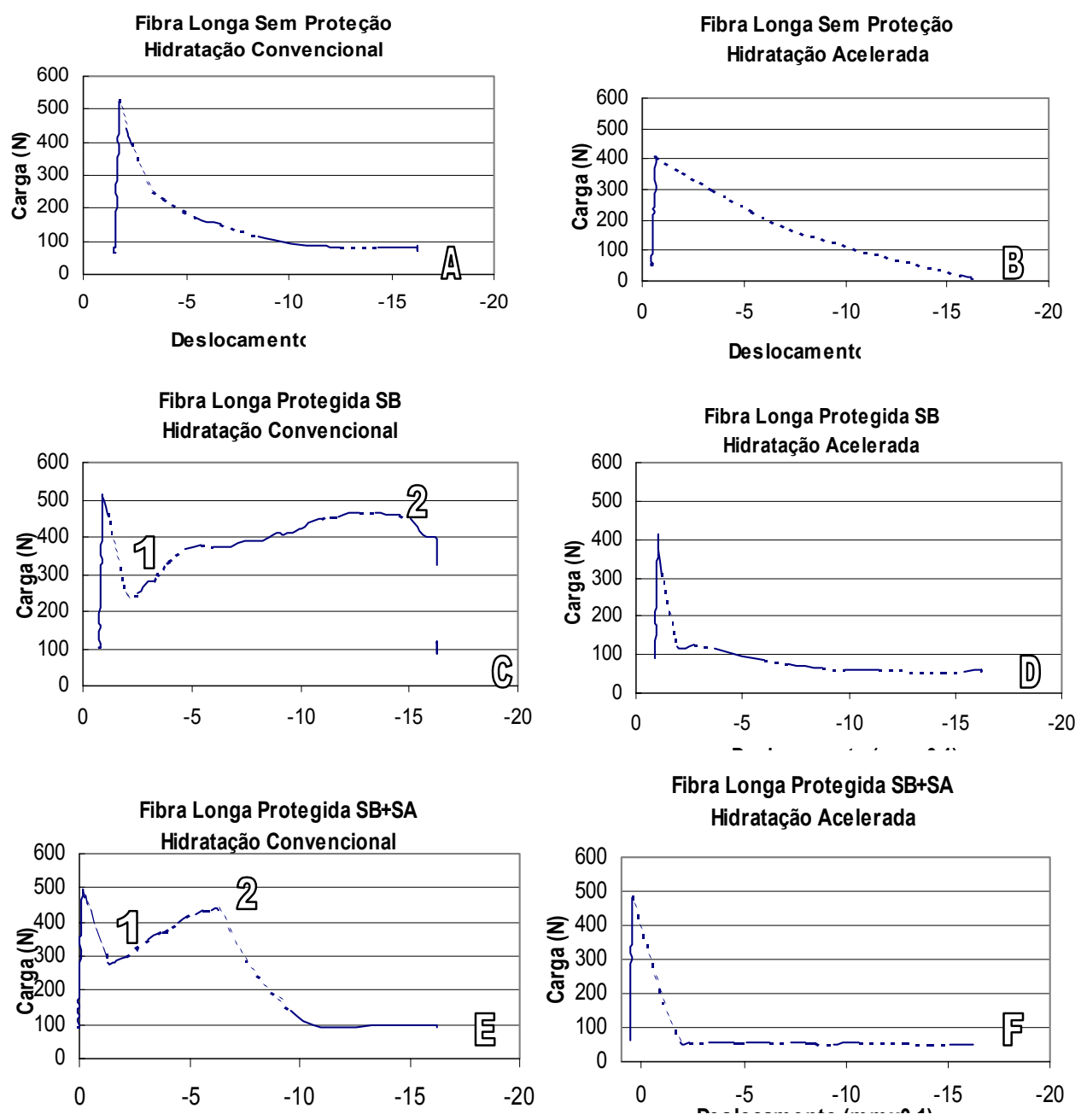

FIGURA 5.15 - Curvas de carga (N) $x$ deslocamento $(\mathrm{mm})$ para placas esbeltas com compósito padrão CP V ARI reforçado com fibras contínuas com proteção superficial

${ }^{18}$ As fibras discretas são distribuídas aleatoriamente pela matriz cimentícia, enquanto as fibras tipo Roving têm sua direção fixada. 
Como se vê na Figura 5.15, a ruptura da fibra de vidro contínua sem proteção superficial, apresentou-se com característica frágil, tanto para as amostras que sofreram processo de hidratação convencional quanto acelerado. Já aquelas com tratamento superficial apresentaram características de ruptura dúctil para o processo de hidratação convencional e ruptura frágil para o processo de hidratação acelerado.

Na Figura 5.15 - C e E, nos pontos indicados, é possível verificar que, em 1 ocorreu o rompimento da argamassa, fazendo com que a fibra trabalhasse à flexão até sua ruptura em 2. Essa situação não se verificou nos casos A, B, D e F, nos quais só se observa a ruptura da argamassa.

\subsection{Microestrutura}

As figuras apresentadas a seguir são fotos da microestrutura dos compósitos cujas fibras de vidro não foram completamente corroídas após processo de hidratação. Essas foram feitas através de equipamento de microscopia óptica, do Departamento de Ciência dos Materiais da USP de São Carlos. 


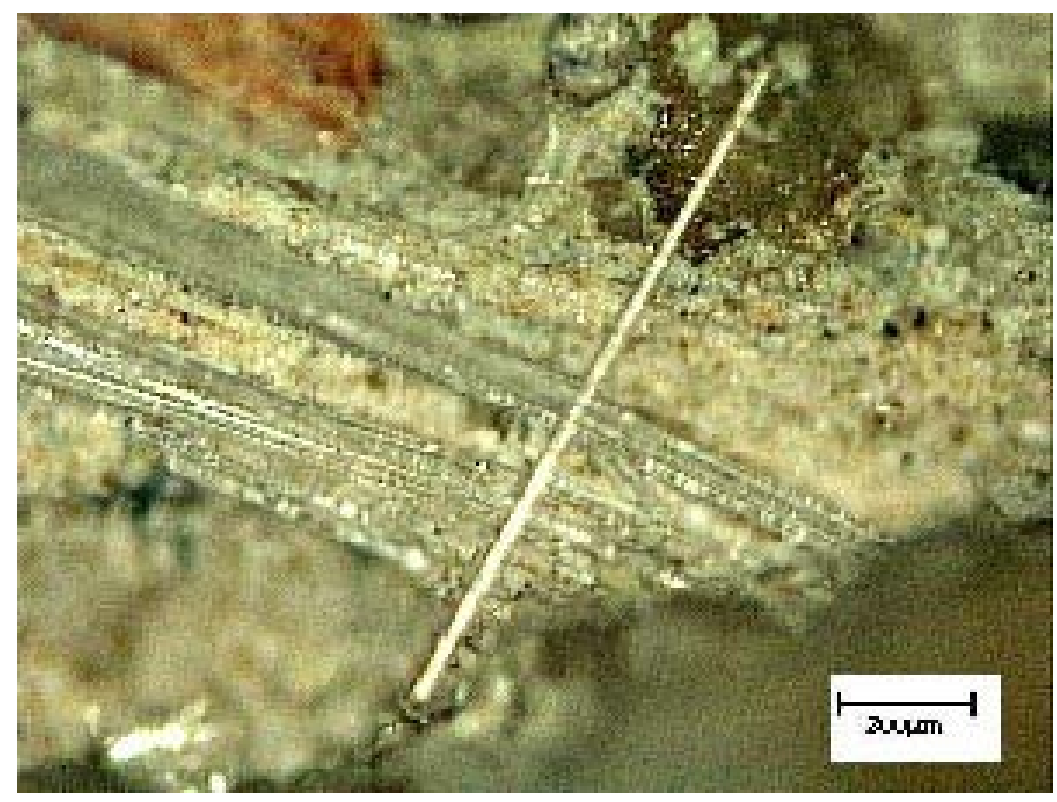

FIGURA 5.16 - Microscopia Óptica (50x) da fibra de vidro do compósito padrão CP III após processo de hidratação convencional

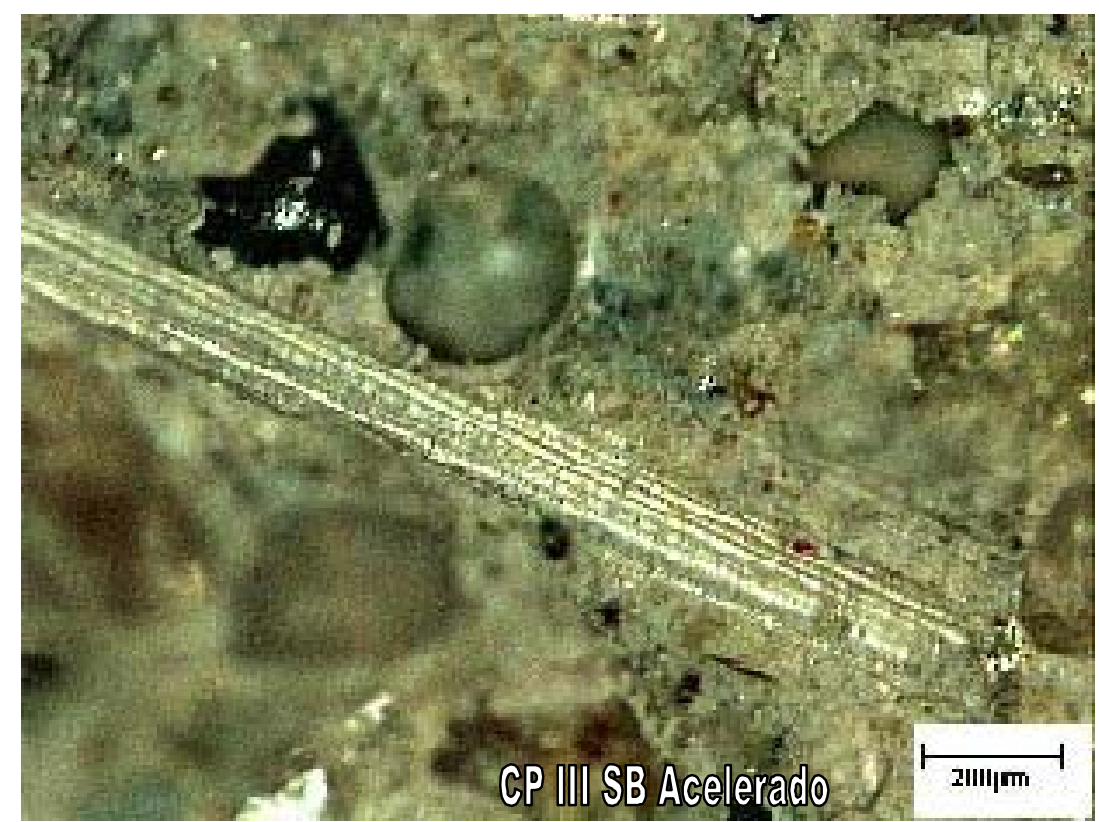

FIGURA 5.17 - Microscopia Óptica (50x) da fibra de vidro do compósito CP III modificado com látex após processo de hidratação acelerado 


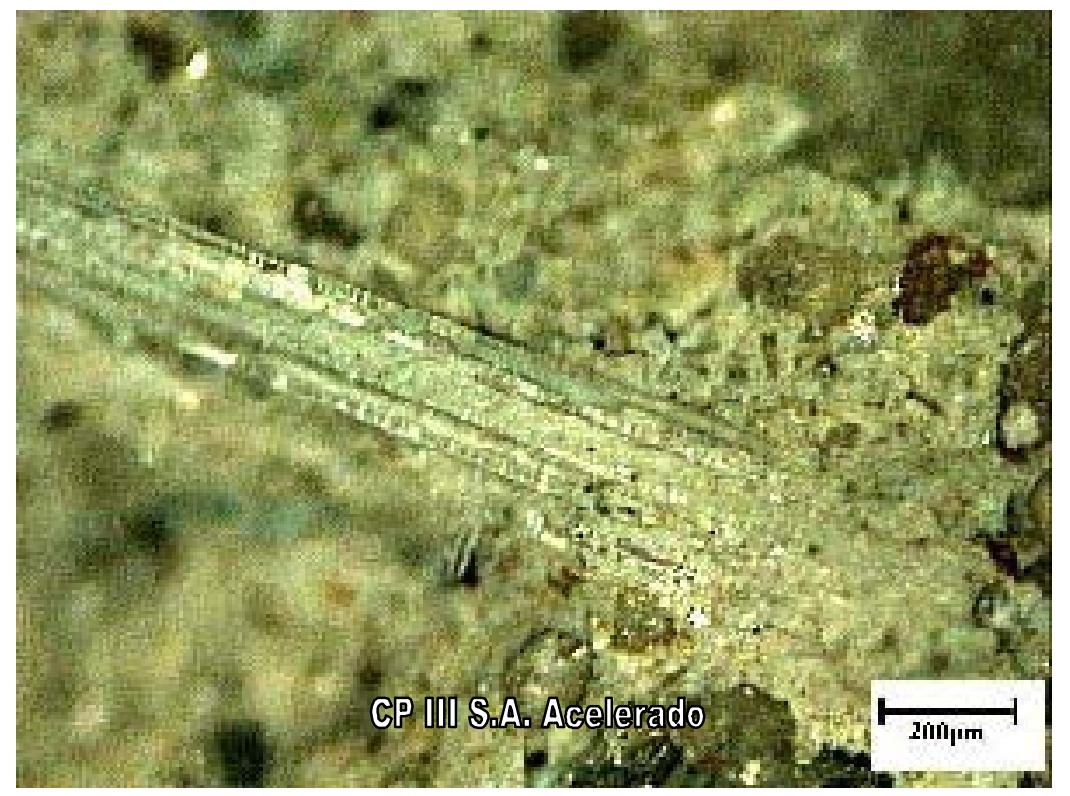

FIGURA 5.18 - Microscopia Óptica (50x) da fibra de vidro do compósito CP III com adição de S.A. após processo de hidratação acelerado

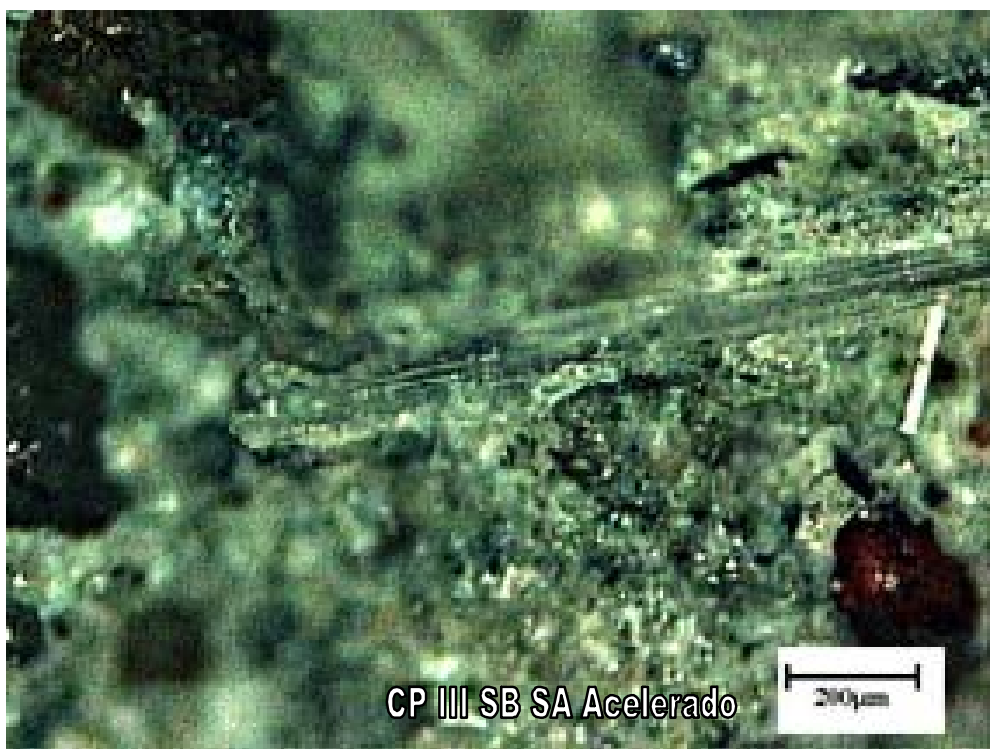

FIGURA 5.19 - Microscopia Óptica (50x) da fibra de vidro do compósito CP III modificado com látex com adição de S.A. após processo de hidratação acelerado 


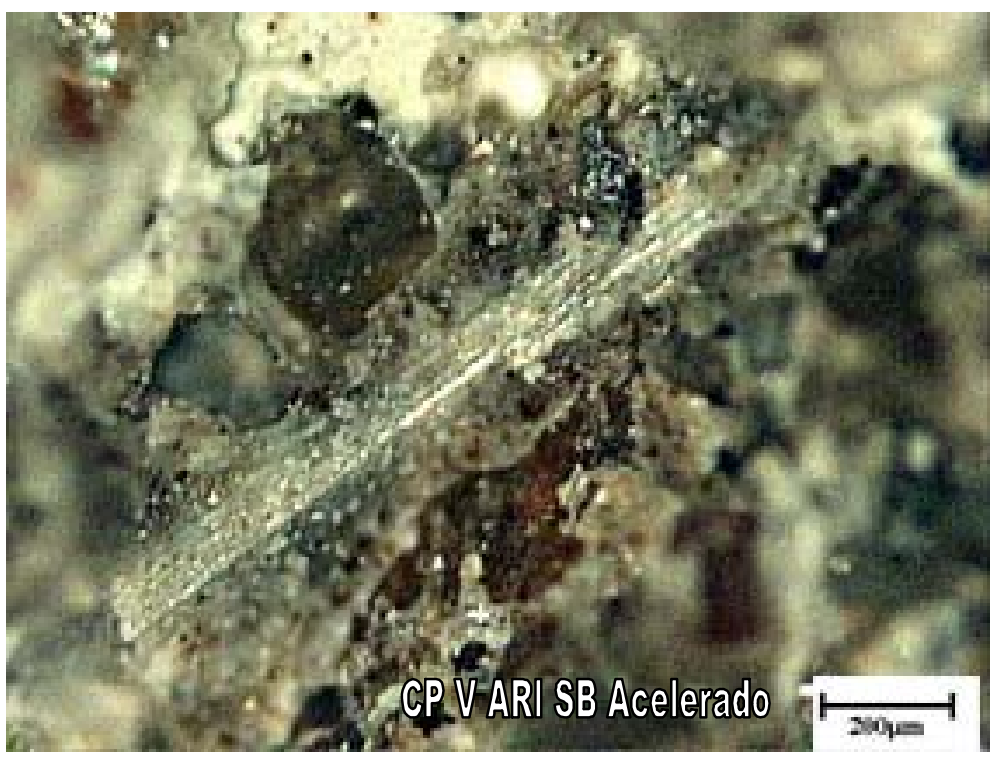

FIGURA 5.20 - Microscopia Óptica (50x) da fibra de vidro do compósito CP V ARI modificado com látex após processo de hidratação acelerado

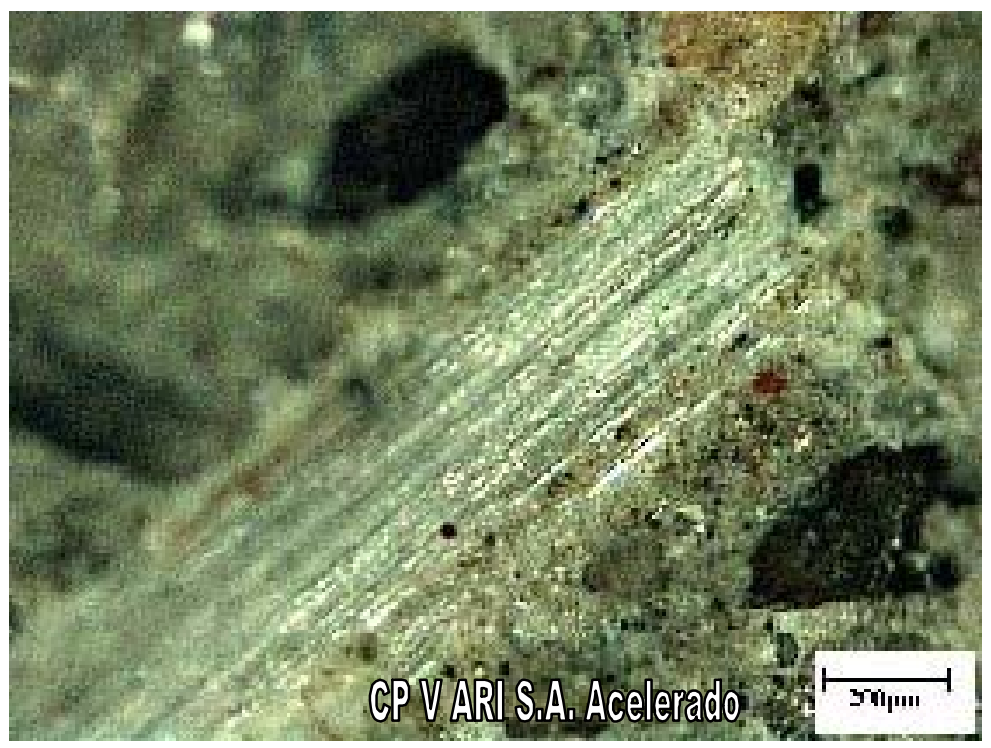

FIGURA 5.21- Microscopia Óptica (50x) da fibra de vidro do compósito CP V ARI modificado com látex após processo de hidratação acelerado 


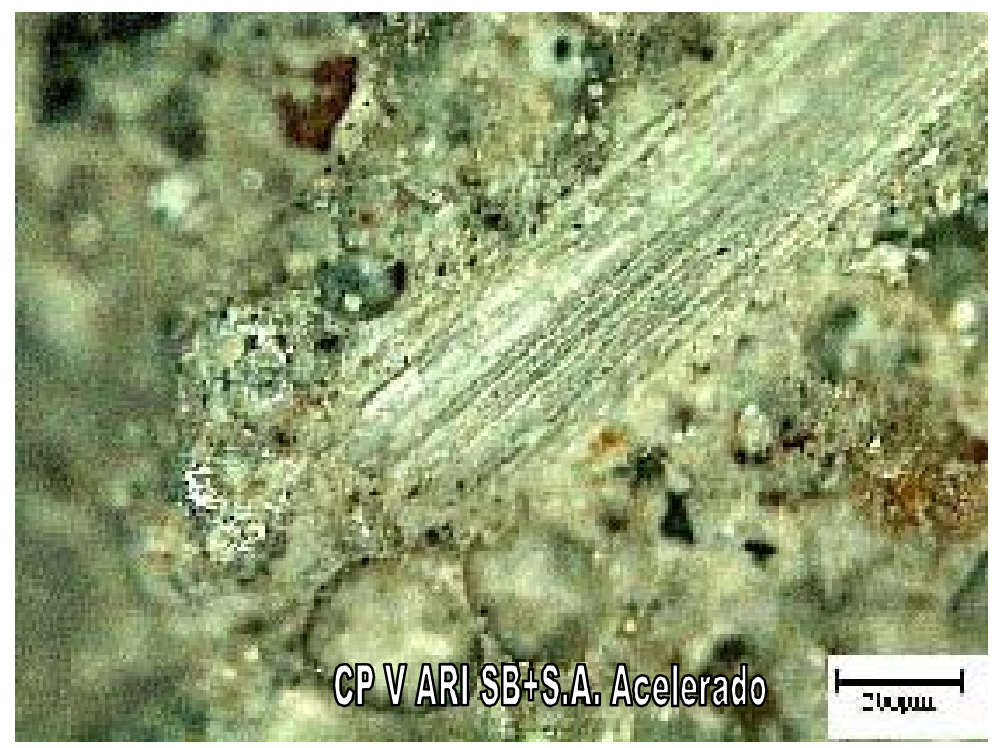

FIGURA 5.22- Microscopia Óptica (50x) da fibra de vidro do compósito CP V ARI modificado com látex e adição de sílica ativa após processo de hidratação acelerado 
Análise dos resultados

\subsection{Resistência à compressão}

Nas Figuras 5.1 e 5.2, nota-se que os compósitos padrão com cimentos CP II E e CP III e o compósito CP III com adição de sílica ativa tiveram um considerável ganho de resistência à compressão $(9,3 \%, 5,4 \%$ e $2,3 \%$ respectivamente). Esse incremento de resistência, deve-se possivelmente ao processo de cura térmica à pressão atmosférica, pela imersão das amostras à $50^{\circ} \mathrm{C}$ e $65^{\circ} \mathrm{C}$, incrementando aquelas resistências que só seriam obtidas com o tempo. Segundo DE MELLO (2000), o aumento da temperatura de cura é uma forma de aumentar a velocidade de hidratação, favorecendo as condições de dissolução/ precipitação e difusão para que os compostos reajam entre si.

Quanto à resistência à compressão das amostras de CP V ARI, o incremento de resistência à compressão pelo processo de hidratação acelerado não foi verificado ou não foi significativo, $(0,6 \%$ para $\mathrm{CP} V \mathrm{ARI}$ padrão e $2,3 \%$ para $\mathrm{CP}$ V ARI com adição de S.A.). Isso se explica pelo fato do CP V ARI ser constituído de 95\% a 100\% de clínquer finamente moído, hidratando-se quase que totalmente em 7 dias.

No caso das amostras modificadas com látex, verifica-se uma queda na resistência à compressão, devido ao processo de hidratação acelerada, possivelmente provocada pela elevação da temperatura da água. Acredita-se que a alta temperatura desta água tenha feito com que o polímero tenha sido lixiviado, aumentando os vazios do compósito, diminuindo a resistência à compressão deste.

\subsection{Resistência à tração na compressão diametral}

Em relação aos resultados dos ensaios de tração na compressão diametral nas Figuras 5.3 e 5.4, observa-se que há uma correspondência no comportamento à compressão axial e à tração na compressão diametral para amostras que sofreram processo de hidratação convencional. Naquelas que sofreram processo de hidratação acelerada, pode-se observar que há queda na resistência para alguns casos (todas amostras padrão e CP V ARI modificada com SB) e ganho na resistência para as 
demais. Acredita-se que as amostras padrão tiveram menor desempenho, devido ao ataque do meio alcalino às fibras de vidro, neutralizando o incremento na resistência à tração na compressão pela adição das fibras.

Nos valores obtidos para amostras de CP V ARI modificado com látex, vale a hipótese da lixiviação do polímero devido à alta temperatura da água do processo de hidratação acelerado. As amostras modificadas com látex compostas por CP III aparentam ser menos susceptíveis à lixiviação do que aquelas compostas por CP V ARI.

\subsection{Tração simples}

Os resultados do ensaio de tração simples da fibra de vidro em forma de roving dos SIC's podem ser vistos nas Figura 5.5 e 5.6. O melhor resultado foi obtido pela amostra padrão CP III + SB + S.A., 10,4 N para as submetidas à hidratação convencional e 6,7 N para o processo de hidratação acelerado. Esse resultado mostra um melhor desempenho das amostras compostas pelo cimento CP III, modificada com látex e com adição de sílica ativa e está de acordo com a bibliografia consultada, indicando os cimentos com alto teor de escória e a adição de sílica ativa para atenuar o ataque alcalino do cimento às fibras de vidro.

\subsection{Módulo de ruptura à flexão}

A Figura 5.7 apresenta valores de módulo de ruptura à flexão de placas esbeltas de argamassas padrão CP III e CP V ARI e suas variações com modificação com látex e adição de sílica ativa, sem reforço com fibras de vidro. Esses valores servem de comparação com aquelas que receberam adição de fibras.

Nas Figuras 5.8 e 5.9, pode-se observar que a queda no valor de módulo de ruptura à flexão foi mais efetivo nas amostras padrão e nas de CP V ARI modificadas com látex e com adição de sílica ativa.

O melhor desempenho das amostras compostas por CP III, tanto padrão como as modificadas com látex e com adição, está de acordo com o indicado pela bibliografia.

Observando apenas as amostras de CP V ARI nota-se maior eficiência nas amostras com adição de sílica ativa, podendo concluir que a hipótese de lixiviação do látex $\mathrm{SB}$, devido à alta temperatura da água do processo de hidratação acelerado, é confirmada. 
As Figuras 5.10, 5.11 e $\mathbf{5 . 1 2}$ apresentam as curvas de carga $\mathrm{x}$ deslocamento para as amostras padrão, modificadas com látex e adição de sílica ativa. Pode-se notar que, para todos os casos, a ruptura das placas à flexão apresentou características frágeis.

As Figuras 5.13 e 5.14 trazem os valores do módulo de ruptura da argamassa padrão CP V ARI reforçada com fibras contínuas roving com tratamento superficial. Para aquelas amostras que sofreram processo de hidratação convencional, as fibras de vidro contínuas apresentaram incremento no módulo de ruptura se comparadas às argamassas sem fibras (Figura 5.7). Para as amostras que sofreram processo de hidratação acelerado, aquelas reforçadas com fibra de vidro sem proteção superficial tiveram uma queda no módulo de ruptura maior e uma queda menor foi verificada para aquelas reforçadas com fibras com camada de proteção superficial.

Observando-se a Figura 5.15, nota-se que a ruptura apresenta-se frágil para todas as amostras com fibras de vidro contínuas, quando submetidas tanto ao processo de hidratação convencional quanto ao acelerado. Esse resultado confirma a grande susceptibilidade da fibra de vidro tipo E ao meio alcalino do cimento Portland.

O comportamento das amostras com proteção superficial apresentou característica dúctil para aquelas reforçadas com fibras protegidas, submetidas a processo de hidratação acelerado. Nas Figuras 5.15.C e 5.15.E, pode-se observar dois picos de carga bastante característicos, o primeiro com a ruptura da argamassa (ponto 1), a seguir um patamar com a fibra de vidro trabalhando, e um segundo pico, no qual a fibra se rompe (ponto 2). Já para aquelas submetidas ao processo de hidratação acelerado, a ruptura foi frágil para todos os casos mas, por meio de uma análise visual das amostras, foi possível notar alguma integridade das fibras.

\subsection{Microestrutura}

A análise microestrutural foi feita nos corpos-de-prova cilíndricos rompidos à tração na compressão. Foram utilizadas apenas aquelas amostras cuja presença de fibras pôde ser observada visualmente, após processo de hidratação acelerado. A amostra padrão de CP III com hidratação convencional foi usada como referência. 
A Figura 5.16 apresenta uma fotografia da microestrutura da fibra de vidro encontrada na amostra do compósito padrão CP III, após processo de hidratação convencional, aparentando integridade. Todas as demais fotografias $\mathbf{( 5 . 1 7}$, 5.18, 5.19, 5.20, 5.21, 5.22 e 5.23) apresentam as fibras que aparentam ter sofrido processo de corrosão. 
CAPÍtULO

Conclusões

\section{1. desempenho dos compósitos modificados com látex}

Em relação ao desempenho pouco favorável dos compósitos modificados com látex, BIJEN (1983) já havia observado que "os resultados mostram que, para aquelas amostras de argamassa mantidas imersas em água, o efeito da adição de polímero na durabilidade para as reforçadas com fibra de vidro é menos pronunciada."

Também AFRIDI et al. (1989), analisando argamassas modificadas com látex SB e EVA, por meio de análises feitas pelo DTA/ TGA, observaram que a capacidade do cimento hidratado blindar o $\mathrm{Ca}(\mathrm{OH})_{2}$ no sistema é geralmente menor no SB que no EVA.

Mesmo que a hipótese da lixiviação do látex pela água à $50^{\circ} \mathrm{C}$ e $65^{\circ} \mathrm{C}$ esteja correta, a modificação de matrizes de cimento Portland com látex SB para confecção de elementos construtivos cuja utilização seja no meio ambiente (temperatura por volta dos $30^{\circ} \mathrm{C}$ e umidade relativa do ar em torno de $65 \%$ ) não está inviabilizada. Por outro lado, acredita-se que o processo de hidratação acelerado não é adequado para amostras que recebem látex SB na sua composição.

\section{2. quanto ao tipo de cimento}

Os ensaios mostraram que os compósitos de CP III têm melhor desempenho, em relação ao ataque do meio alcalino do cimento Portland às fibras de vidro. Entretanto, o seu ganho de resistência é lento, analogamente ao do CP V ARI, o que pode requerer um processo de cura acelerado, caso se necessite de produção em escala industrial.

As modificações com látex e a adição de sílica ativa mostraram-se bons procedimentos para os compósitos de CP III, mas seus benefícios não foram suficientes para contornar o ataque do meio alcalino mais intenso do CP V ARI às fibras de vidro.

\section{3. quanto ao benefício da adição de fibras às argamassas}


Não se deve esperar incrementos significativos na ductilidade dos compósitos de cimento Portland com teores de fibras curtas utilizados nesta pesquisa ( $2 \%$ em volume de argamassa), mas sim um auxílio no grampeamento de microfissuras, por exemplo, àquelas oriundas de tensões provocadas por dilatação.

Já das fibras contínuas, na forma de roving ou tela, pode-se esperar uma contribuição mais efetiva na diminuição da fragilidade da ruptura destes compósitos.

\section{4 viabilidade do controle do ataque do meio alcalino à fibra de vidro}

Os resultados apresentados apontam que a modificação com látex SB e adição de sílica ativa reduzem a intensidade do ataque do meio alcalino do cimento Portland à fibra de vidro E, mas esse ataque ainda ocorre com grande intensidade, necessitando de estudos posteriores, com novos tipos de látex e maiores teores de sílica ativa.

\subsection{Perspectivas}

Embora nesta pesquisa tenha-se conseguido reduzir o ataque alcalino às fibras de vidro, os resultados são muito modestos para viabilizar a utilização dessas fibras em concretos ou argamassas de cimento Portland. Para tanto, futuramente pretende-se melhorar o nível dessa proteção.

Os resultados do presente trabalho necessitam ser analisados sob o ponto de vista microestrutural, ampliando o entendimento do fenômeno da reação do meio alcalino produzido na hidratação do cimento Portland com a fibra de vidro e a efetividade do mecanismo de proteção superficial com látex e a sílica ativa à fibra. 


\section{Ensaio de Kantro}

\section{I . 1) Descrição do ensaio}

O procedimento consiste de um tronco de cone feito de material translúcido cujas dimensões são: altura $6,00 \mathrm{~cm}$, diâmetro inferior $4,00 \mathrm{~cm}$ e diâmetro superior 2,00 cm, como mostra a Figura I .1.
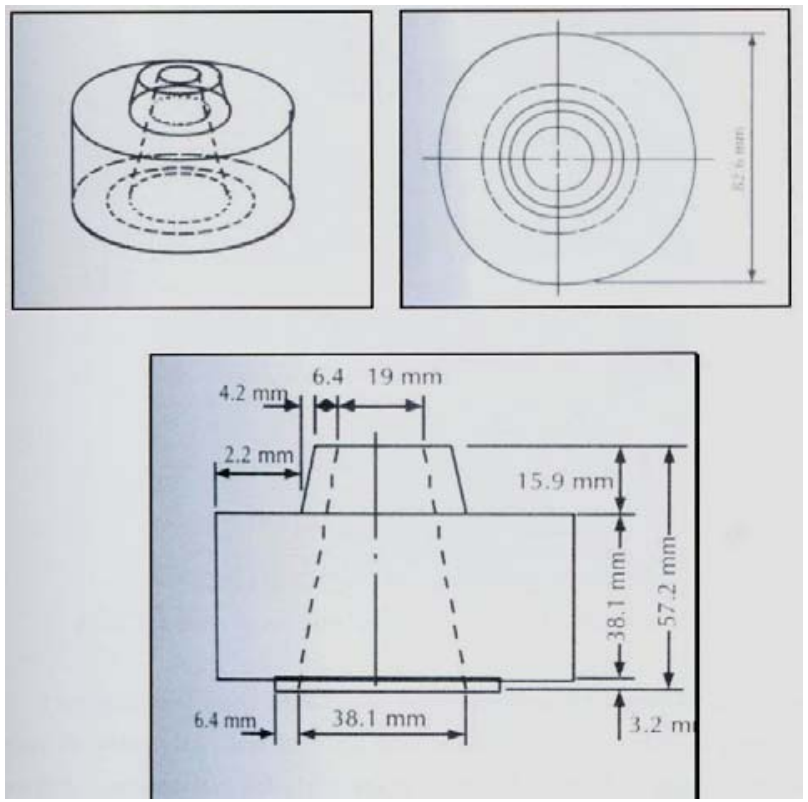

FIGURA I.1 - Representação esquemática do tronco de cone para ensaio de "mini slump" (Kantro, 1980)

O cone é assentado sobre uma placa de vidro plano e liso, nivelado horizontalmente e recebendo um material que lubrificará o contato entre a pasta e a superfície do vidro. Após seu preenchimento com pasta de cimento e posterior rasamento, o cone é levantado, permitindo que a pasta flua sem nenhum impedimento até o seu equilíbrio em estado de repouso. A área que a projeção vertical do corpo de prova nesta condição abrange sobre a placa de vidro é medida com planímetro ou outro procedimento equivalente. (BUCHER, 1988)

A Figura 7.3 apresenta uma seqüência de fotos mostrando o ensaio do Tronco de Cone. 

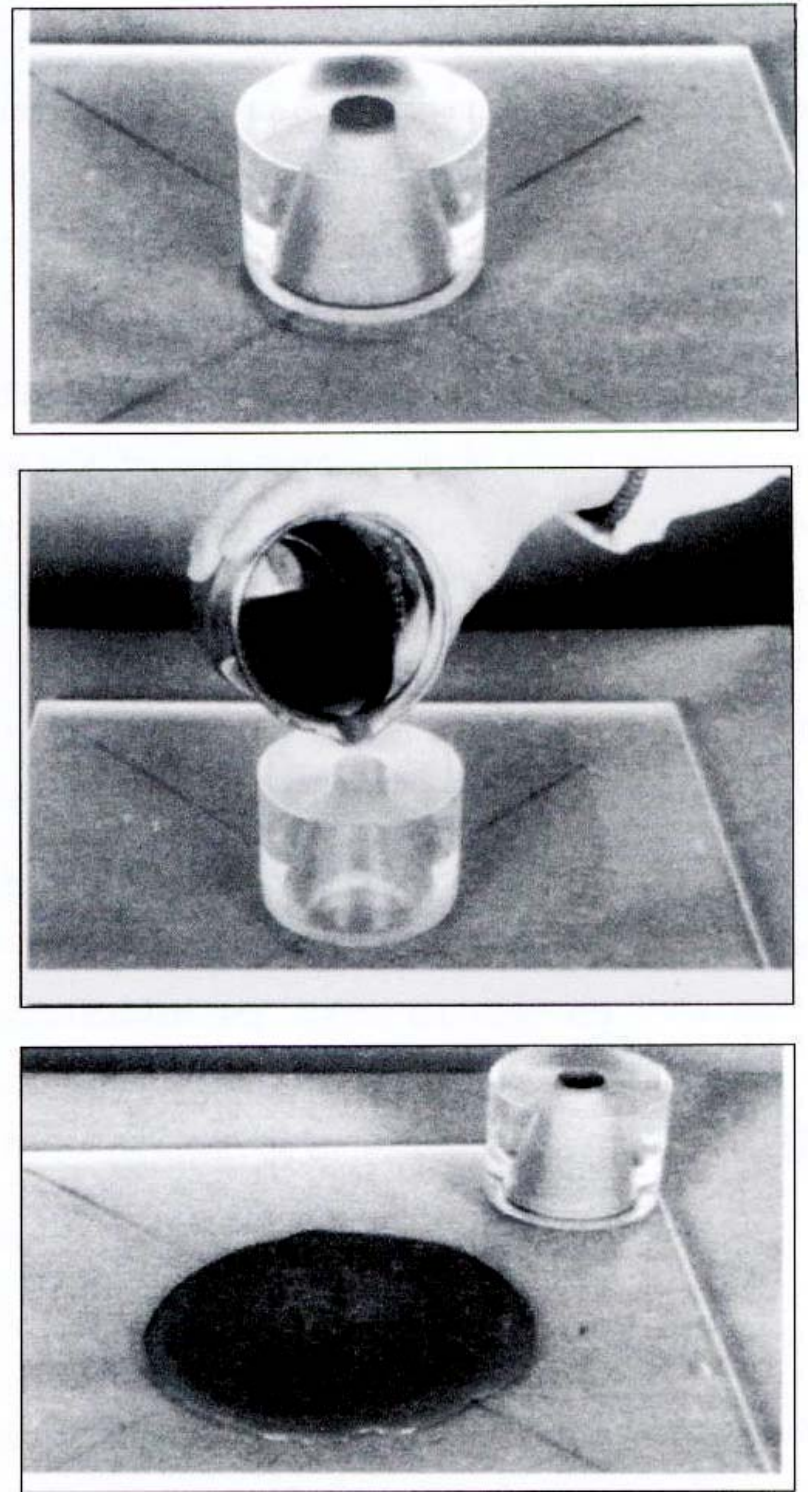

Figura I . 2 - Seqüência de fotos mostrando o ensaio do Tronco de Cone (KANTRO, 1980)

Segundo BUCHER (1988), o método de Kantro utiliza a área de espalhamento correspondente à relação água/ cimento de 0,36 como base de referência ou comparação do efeito reológico instantâneo ou diferido de uma pasta de cimento Portland com água destilada ou desmineralizada. Para um determinado cimento as área de espalhamento das pastas com relação a/ c entre 0,36 e, ao redor, de 0,60 são proporcionais de maneira direta e linear e as divergências com esta tendência provém apenas da uniformidade física e geométrica do substrato (rugosidade, tensão superficial, etc.) ou dos resíduos de pasta que, eventualmente, ficam aderidos às paredes internas do molde no lugar de acompanhar a massa de teste no seu espalhamento pelo substrato. 
A maneira mais simples de utilizar o método de Kantro é variar as relações a/c de 0,36 a 0,6 para cada cimento; sendo que para mesma relação a/ c as áreas de espalhamento são completamente diferentes. Obviamente que aquele cimento cuja pasta mais se expande, com uma determinada quantidade fixa de água de amassamento, é o aglomerante que apresenta o menor requerimento de água para atender a uma certa consistência. Esta é uma característica desejável dos cimentos e pode ser denominada como sensibilidade à água do aglomerante. A partir daí, variase as relações a/c para cada cimento, através da adição de aditivos redutores de água.

\section{(BUCHER, 1988)}

\section{I . 2) Curvas obtidas}

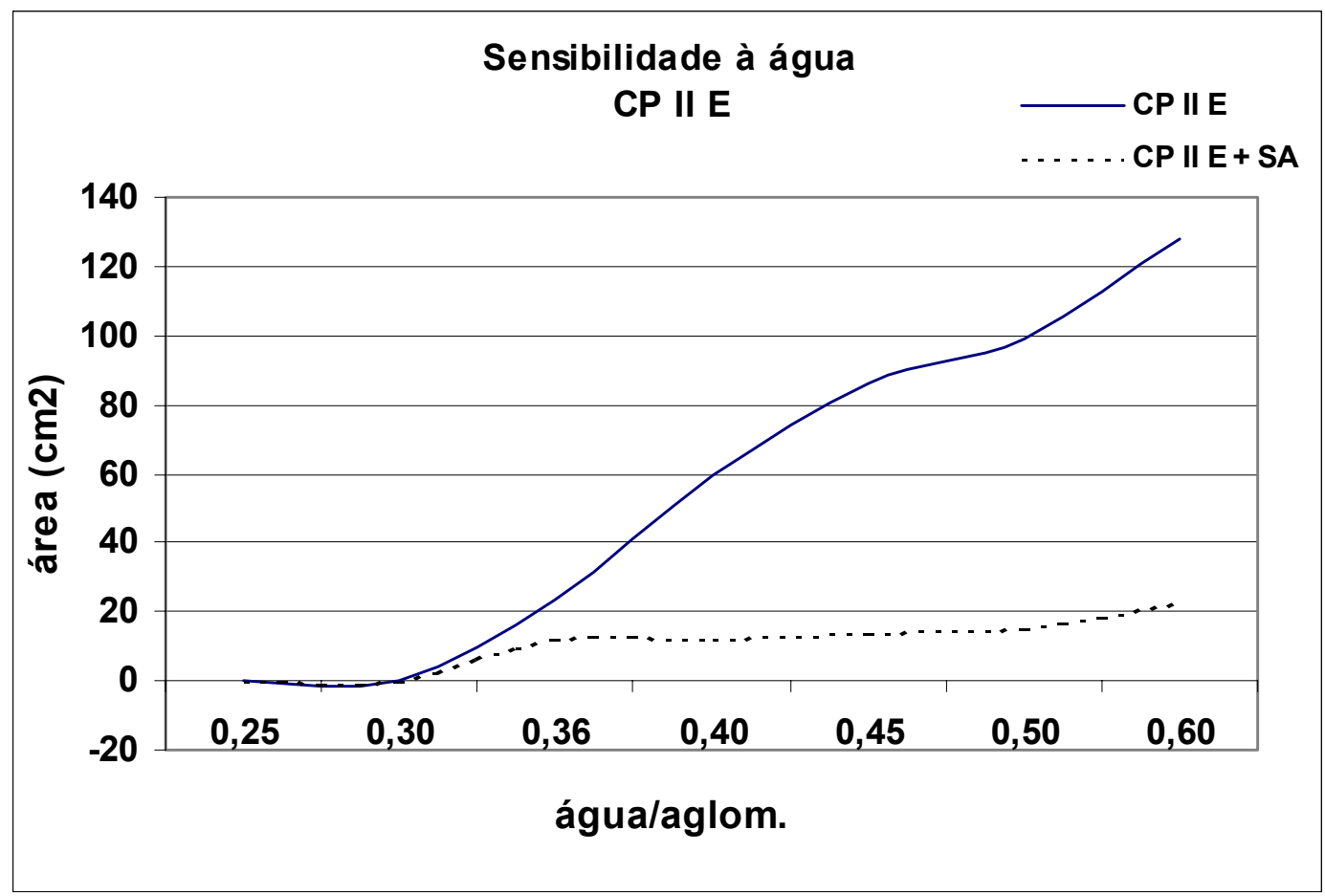

FIGURA I . 3 - Curva de sensibilidade à água do cimento CP II E e CP II E + sílica ativa 


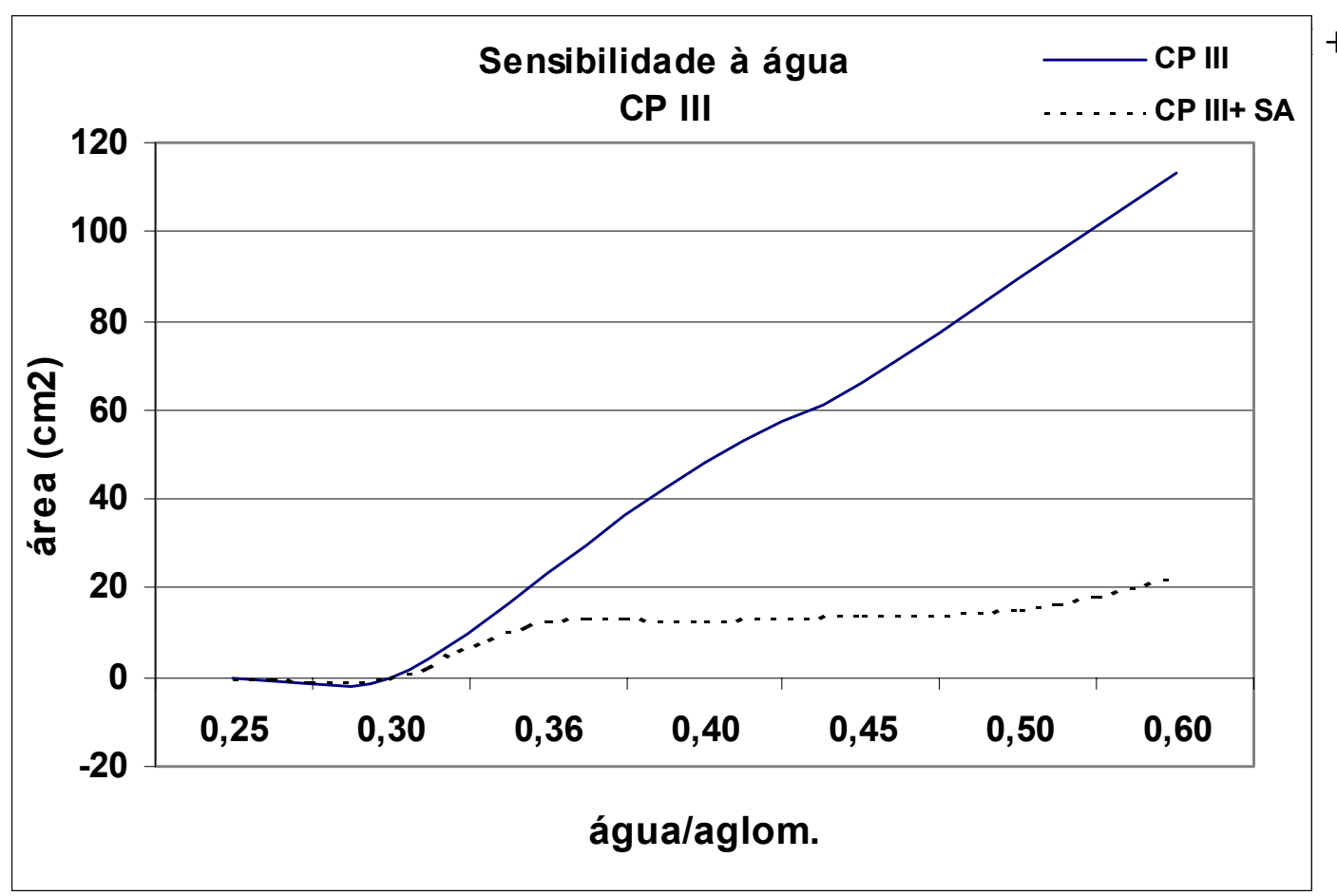

FIGURA I . 4 - Curva de sensibilidade à água do cimento CP III e CP III + sílica ativa

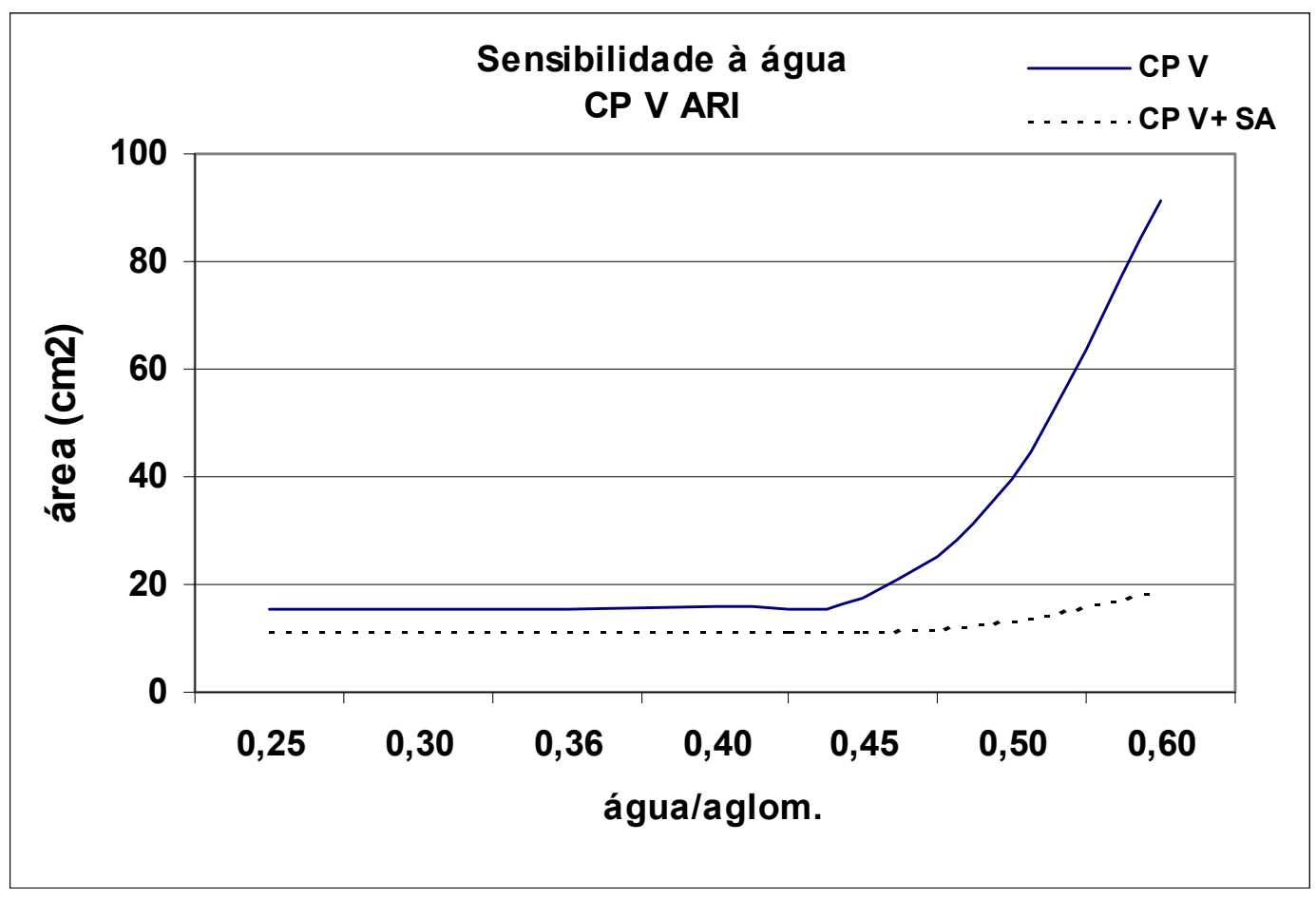

FIGURA I . 5 - Curva de sensibilidade à água do cimento CP V ARI e CP V ARI + sílica ativa 


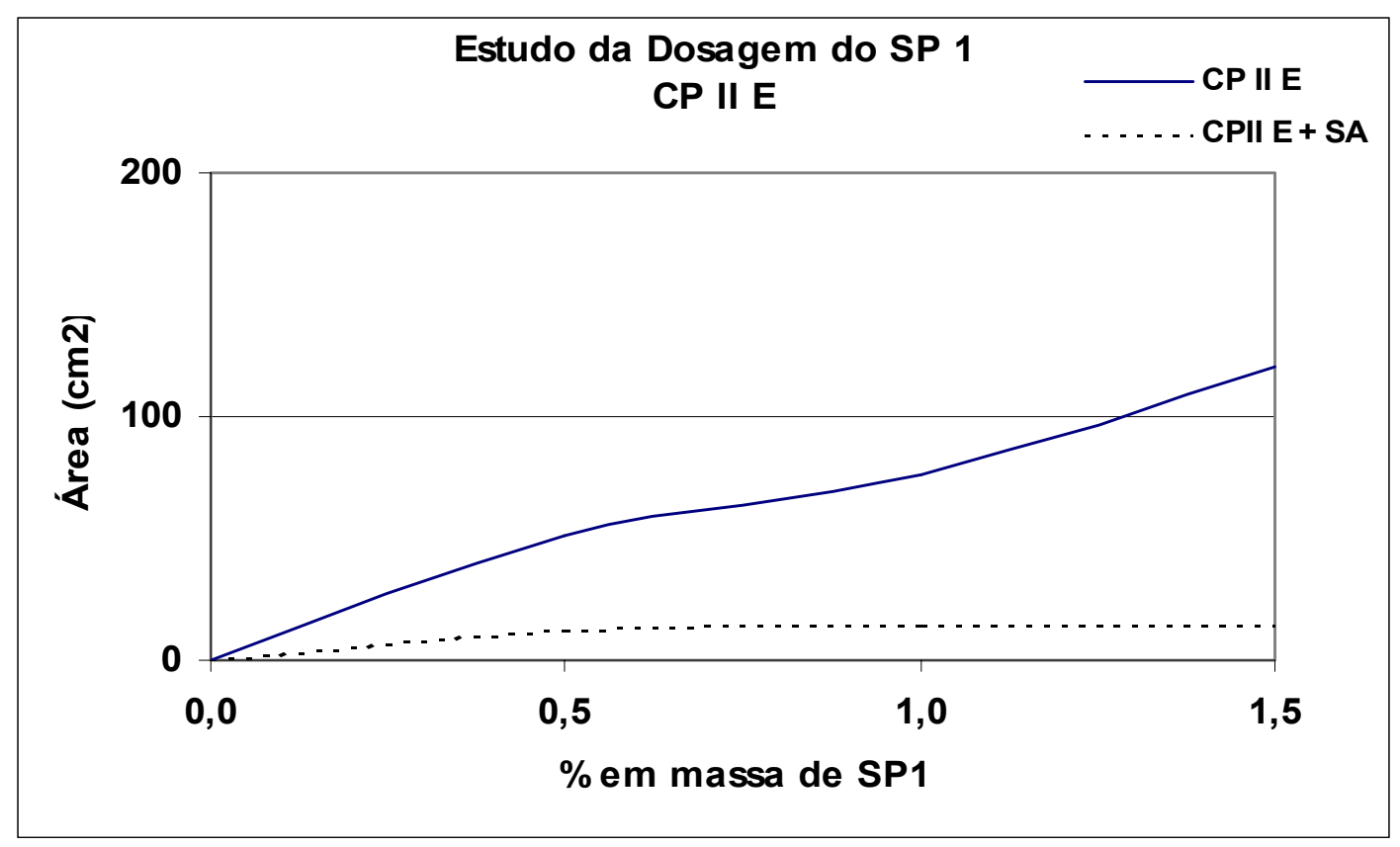

FIGURA I . 6 - Área de espalhamento da pasta de cimento CP II E e CP II E + sílica ativa para vários teores de $\mathrm{SP} 1 \mathrm{com}$ relação água/aglomerante fixada em 0,36

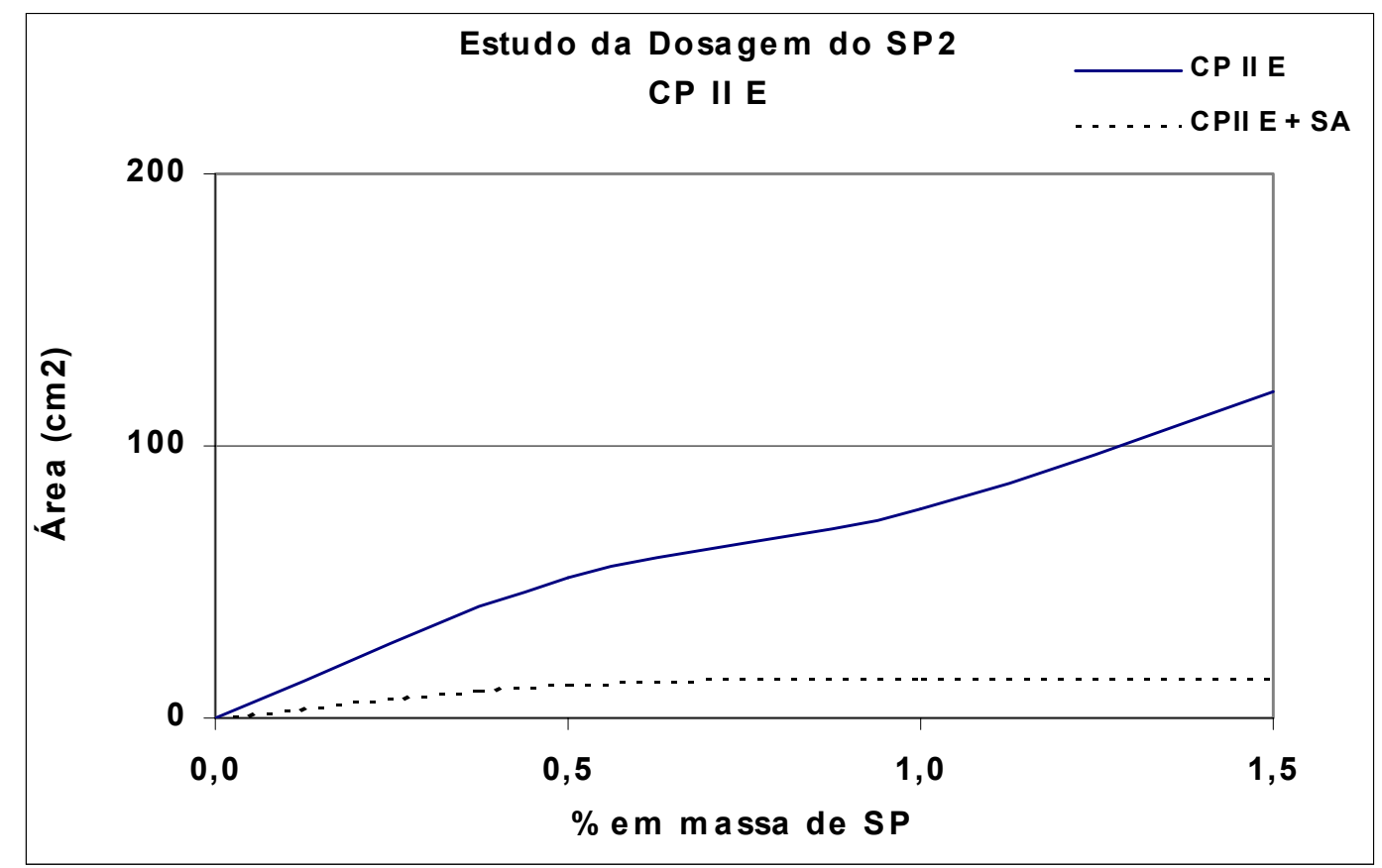

FIGURA I . 7 - Área de espalhamento da pasta de cimento CP II E e CP II E + sílica ativa para vários teores de SP 2 com relação água/aglomerante fixada em 0,36 


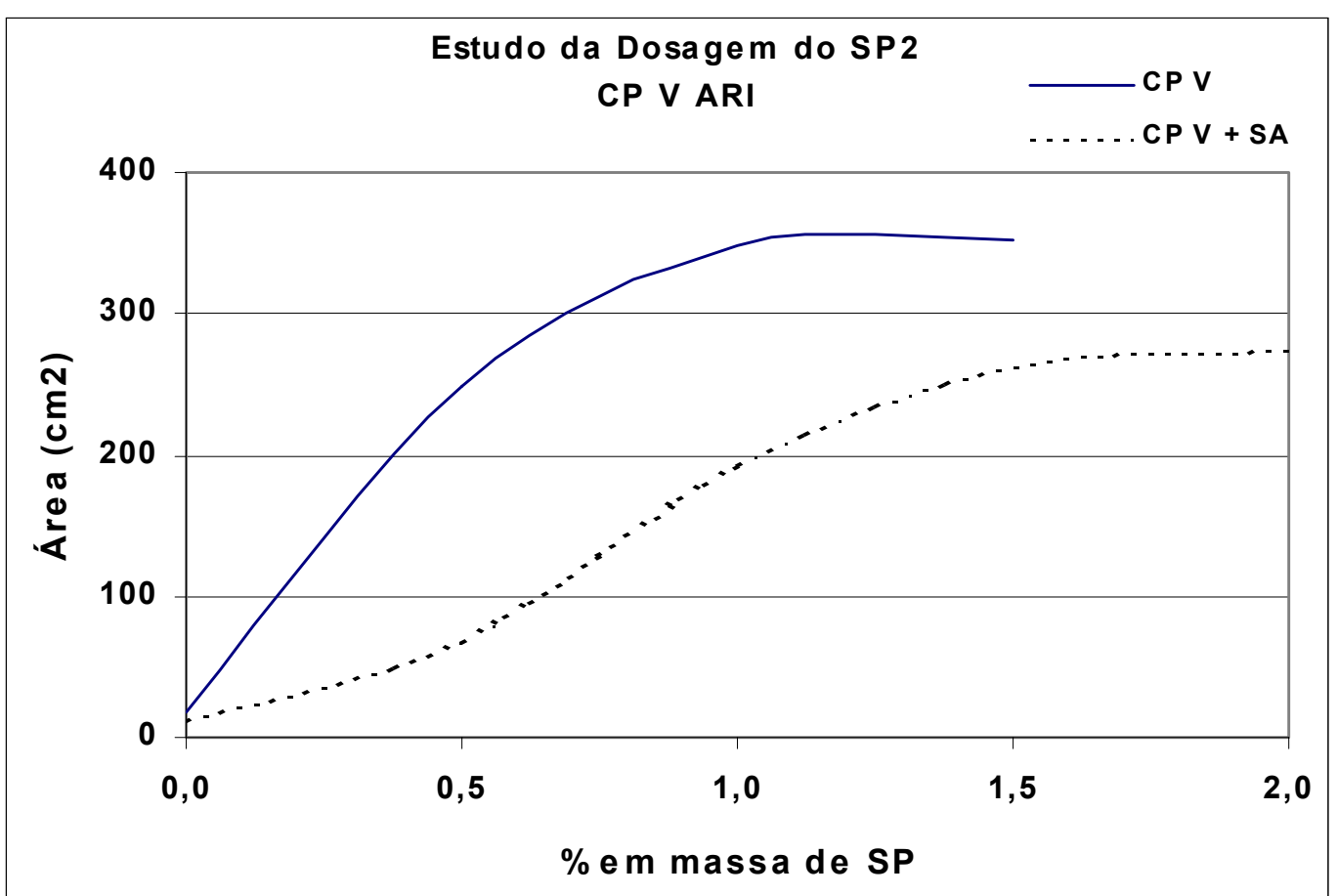

FIGURA I . 8 - Área de espalhamento da pasta de cimento CP V ARI e CP V ARI + sílica ativa para vários teores de SP 2 com relação água/aglomerante fixada em 0,36 


\section{Ensaio de Consistência}

O ensaio foi realizado segundo ABNT 7215/1982.

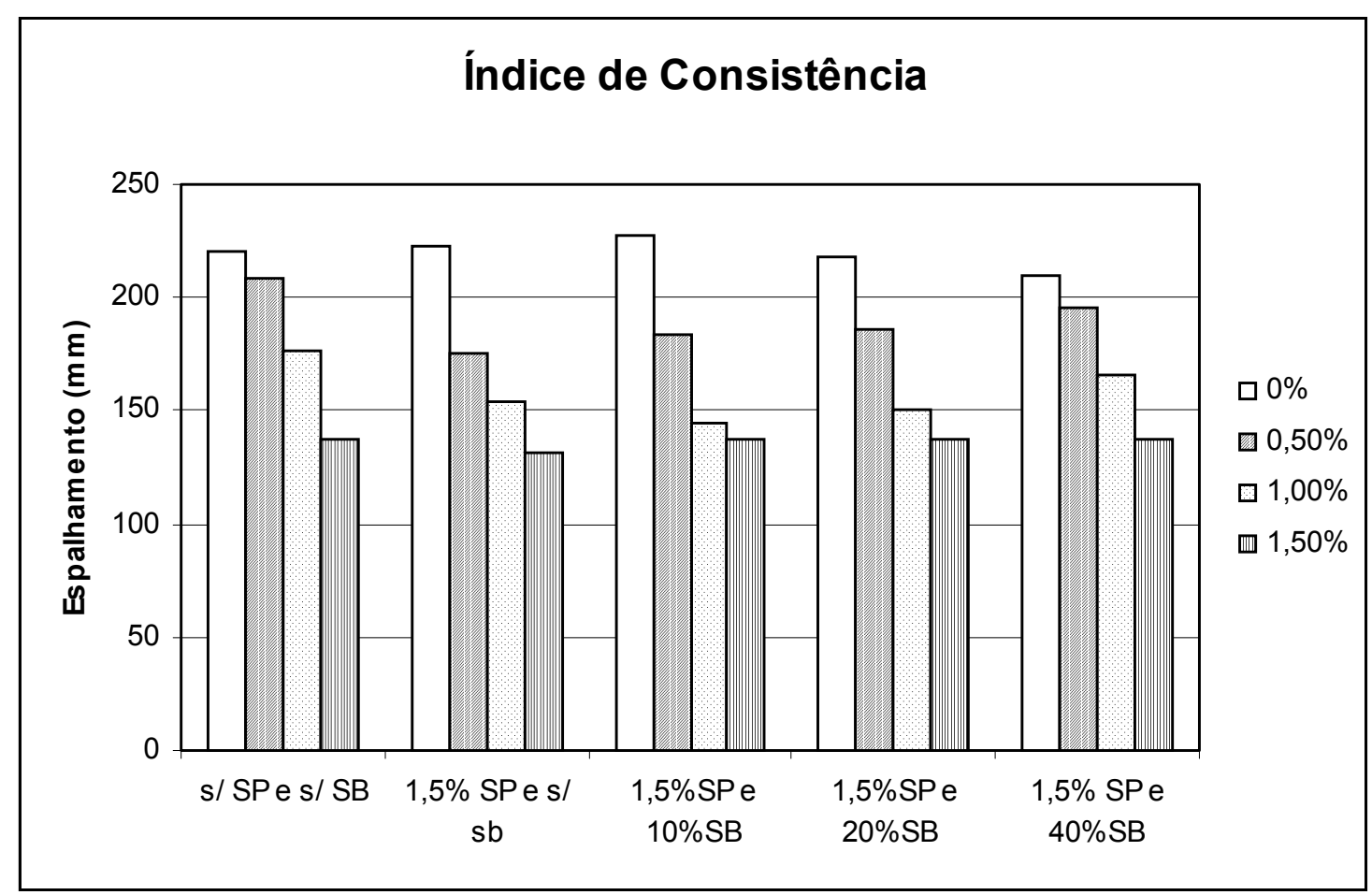

FIGURA II . 1 - Índice de consistência para argamassas de CP II E 32 com adição de fibra de vidro discreta 


\section{ANEXO III}

Ensaio de Resistência à Compressão axial

\begin{tabular}{|c|c|c|c|c|}
\hline Amostra & SP $1(\%)$ & Látex SB (\%) & Fibra (\%) & $\mathbf{a} / \mathbf{c}$ \\
\hline 1 & 0.0 & 0 & 0,0 & 0,56 \\
\hline 2 & 1.5 & 0 & 0,0 & 0,50 \\
\hline 3 & 1.5 & 10 & 0,0 & 0,46 \\
\hline 4 & 1.5 & 20 & 0,0 & 0,40 \\
\hline 5 & 1.5 & 40 & 0,0 & 0,32 \\
\hline 6 & 0 & 0 & 0,5 & 0,56 \\
\hline 7 & 0 & 0 & 1,0 & 0,56 \\
\hline 8 & 0 & 0 & 1,5 & 0,56 \\
\hline 9 & 1.5 & 0 & 0,5 & 0,56 \\
\hline 10 & 1.5 & 0 & 1,0 & 0,56 \\
\hline 11 & 1.5 & 0 & 1,5 & 0,56 \\
\hline 12 & 1.5 & 10 & 0,5 & 0,46 \\
\hline 13 & 1.5 & 10 & 1,0 & 0,46 \\
\hline 14 & 1.5 & 10 & 1,5 & 0,46 \\
\hline 15 & 1.5 & 20 & 0,5 & 0,40 \\
\hline 16 & 1.5 & 20 & 1,0 & 0,40 \\
\hline 17 & 1.5 & 20 & 1,5 & 0,40 \\
\hline 18 & 1.5 & 40 & 0,5 & 0,32 \\
\hline 19 & 1.5 & 40 & 1,0 & 0,32 \\
\hline 20 & 1.5 & 40 & 1,5 & 0,32 \\
\hline
\end{tabular}

TABELA III . 1 - Composição dos compósitos dos ensaios preliminares O ensaio de compressão axial foi realizado segundo a NBR 7215/1982. 


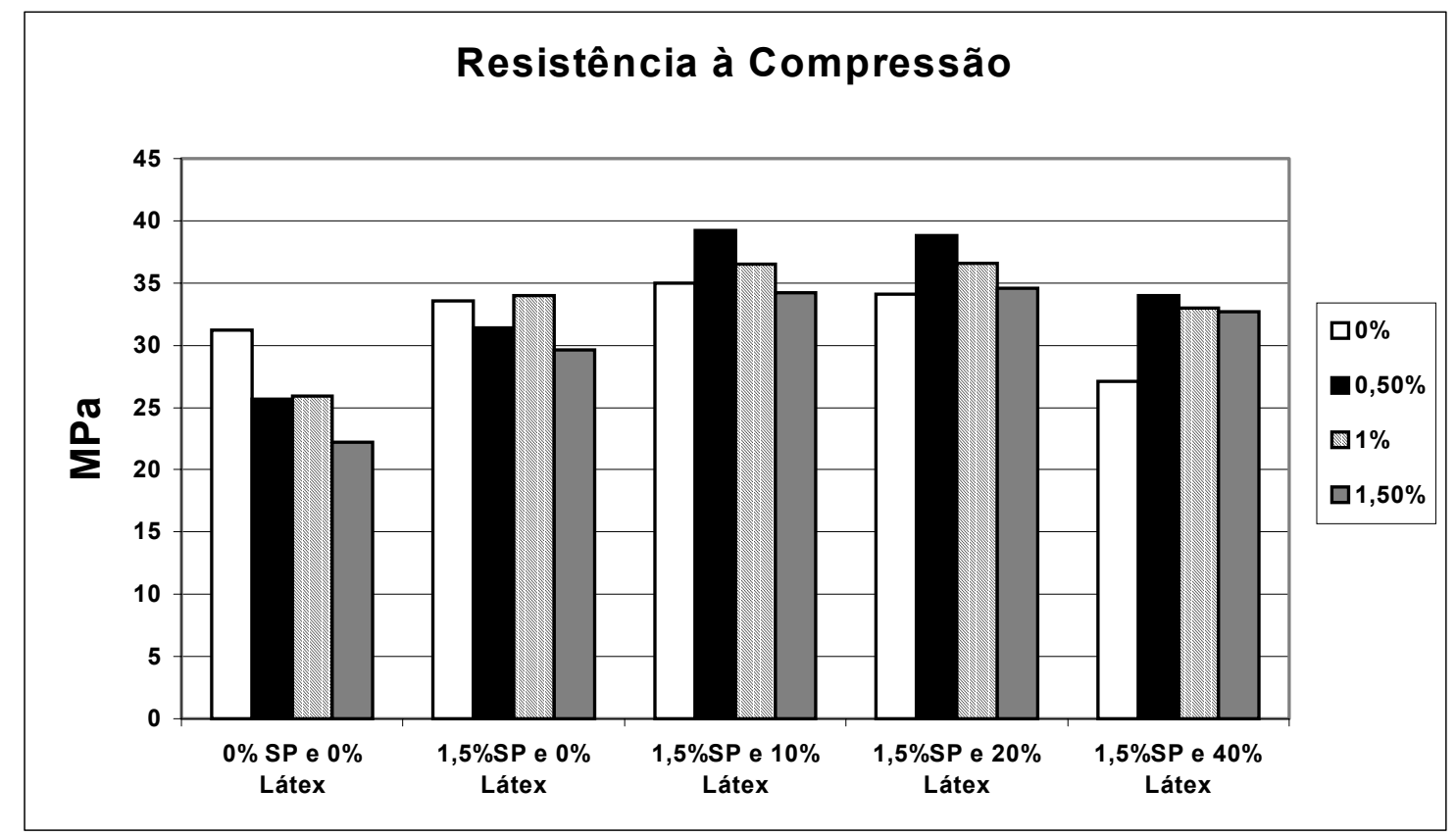

FIGURA III . 1 - Resistência à compressão axial das amostras de CP II E 32 dos ensaios preliminares 


\section{Referências Bibliográficas}

ACI COMITTE 548.1R-92 - Guide for the use of polymers in concrete. 1992

AFRIDI, M. U. K.; OHAMA, Y., Zafar, I. , DEMURA, K. - Behaviour of $\mathrm{Ca}(\mathrm{OH})_{2}$ in polymer modified mortars. The International journal composites and lightweight concrete, vol. 11, n 4, von 1989

AÏTCIN, P. C. - Concreto de alto desempenho. Editora PINI. São Paulo. 2000

ASSOCIAÇÃO BRASILEIRA DE NORMAS TÉCNICAS - NBR 7215 - Ensaio de cimento Portland - método de ensaio. ABNT. Rio de Janeiro. 1982

ASSOCIAÇÃO BRASILEIRA DE NORMAS TÉCNICAS - NBR 7222 Argamassas e concretos - determinação da resistência à tração por compressão diametral de corpos-de-prova cilíndricos. ABNT. Rio de Janeiro. 1983

AMERICAN SOCIETY FOR TESTING AND MATERIALS - ASTM C 947 Standard test method for flexural properties of thin-section glass-fiberreinforced concrete (using simple beam with third-point loading. Philadelphia. 1989

AMERICAN SOCIETY FOR TESTING AND MATERIALS - ASTM C 1185 Standard tests methods for sampling and testing non-asbestos fiber-cement flat sheet, roofing and siding shingles, and clapboards. Philadelphia. 1996

BARTOS, P. J. M. \& ZHU, W. - Effect of microsilica and acrylic polymer treatment on the ageing of GRG. Cement \& concrete composites. Ed 18. 1996

BIJEN, J. - Improved mechanical properties of glass fibre reinforced cement by polymer modification. Anais do simpósio internacional sobre materiais reforçados com fibras para construção civil. EPUSP. São Paulo. 1993

BUCHER, H. R. E. - Desempenho de aditivos redutores de água de alta eficiência em pastas, argamassas ou concretos. $30^{\circ}$ IBRACON. Anais. 1988

DE MELLO, A. B. - Influência da cura térmica (vapor) sob pressão atmosférica no desenvolvimento da microestrutura dos concretos de cimento Portland. tese de doutorado. Escola de Engenharia de São Carlos. Instituto de Física de São Carlos. Instituto de Química de São Carlos. USP. São Paulo. 2000

EKANE, E. B. - Estudo de fissuração em concreto armado com fibras e armadura convencional. Dissertação de mestrado. Escola de Engenharia de São Carlos. USP. São Paulo. 1999

GUIMARÃES, A. E. P. - Análise de pilares de concreto de alta resistência com adição de fibras metálicas submetidos à compressão centrada. Tese de doutorado. Escola de Engenharia de São Carlos. USP. São Paulo. 1999

KANTRO, D . L. - Influence of water reducing admixtures on properties of cement paste. A miniature slump test. Cement, concrete and aggregate, vol. 2, n.2, 1980

KATTAR, J. E. \& ALMEIDA, N. J. - Cimento Portland. Publicação da Holdercim do Brasil. São Paulo. 1999 
LITHERLAND, K. L., OAKLEY, d. R., PROCTOR, B. A . - The use of accelerated ageing procedures to predict the long term strength of GRC composites, Cemente and Concrete Research, vol. 11, p. 455-466, Pergamon Press Ltda, 1981

MANO, E. B. - Introdução a Polímeros. Ed. Edgard Blücher Ltda. 1985

MARTEN, B. - Glass fibres for cement \& concrete. Concrete magazine. November / december. 1988

MEHTA, P. K. \& MONTEIRO, P. J. M. - Concreto estrutura, propriedades e materiais. Editora PINI. São Paulo. 1994

MORAIS, J. A. - Estudo de microconcretos leves de alto desempenho para pré fabricados de pequena espessura. Dissertação de mestrado. EESC. USP.2001

NEVILLE , A. M. - Propriedades do concreto. $2^{\text {a }}$ edição. Editora PINI. São Paulo.1997

OHAMA, Y - Polymer-based admixtures. Cement and concrete composites. ed. 20. Elsivier science. 1998

OLIVEIRA, C. T. A. \& AGOPYAN, V. - Estudo da água do poro de pastas de cimento de escória pelo método da água de equilíbrio. Boletim técnico da escola Politécnica da USP . São Paulo. 2000

PARDELA, M. L. S. \& DEL AGUILA, A. - El envelhecimiento de las pastas de cemento reforzadas com fibras de vidrio. Revista Materiales de Constucción, vol. 42. N. 226. Abril / mayo / junio. 1992

PURNELL, P., SHORT, N. R., PAGE, C. L., MAJUNDAR, A. J. - Microestrutural observations in new matrix glass fibre reinforced cement. Cement and concrete research, ed. 30. 2000

PURNELL, P. - Super-critical carbonation. www.eng.warwick.ac.uk. 2001

ROSSIGNOLO, J. A. - Propriedades da argamassa de cimento portland modificada com látex estireno-butadieno para revestimentos de fachadas. Dissertação de mestrado. Escola de Engenharia de São Carlos. USP. São Paulo.1999

ROSSIGNOLO, J. A. \& AGNESINI, M. V. C. - Estudo da influência da cura úmida nas resistências iniciais dos microconcretos leves modificados com polímero. $42^{\circ}$ IBRACON. Anais. 2000

SAVASTANO JR, H. - Materiais à base de cimento reforçados com fibra vegetal: reciclagem de resíduos para construção de baixo custo. Tese de livre docência. EPUSP. São Paulo. 2000

SEIDLER, N. - Efeito da sílica ativa na alcalinidade e consumo de hidróxido de cálcio durante a hidratação do cimento. $43^{\circ}$ IBRACON. Anais. 2001

STORTE, M. - Látex estireno-butadieno aplicação em concretos de cimento e polímero. Dissertação de mestrado. Escola Politécnica da USP. São Paulo. 1991)

TEZUKA, I. - Concreto armado com fibras. ABCP. São Paulo . 1989

TEZUKA, I. - Concreto de cimento e polímero. ABCP. São Paulo. 1988

WALTERS, D. G. - What are latex?. Concrete intenational design \& constrution. Vol 9. n 12. Dez. 1987 